This document is the accepted manuscript version of the following article:

Lothenbach, B., Xu, B., \& winnefeld, F. (2019). Thermodynamic data for magnesium (potassium) phosphates. Applied Geochemistry, 111, 104450 (21 pp.).

https://doi .org/10.1016/j.apgeochem.2019.104450

This manuscript version is made available under the CC-BY-NC-ND 4.0

license http://creativecommons.org/1icenses/by-nc-nd/4.0/

\title{
1 Thermodynamic data for magnesium (potassium) phosphates
}

2 Barbara Lothenbach ${ }^{\mathrm{a}, \mathrm{b}^{*}}$, Biwan Xu $^{\mathrm{a}}$, Frank Winnefeld ${ }^{\mathrm{a}}$

$3 \quad$ a: Laboratory for Concrete \& Construction Chemistry, Swiss Federal Laboratories for

4 Materials Science and Technology (Empa), 8600 Dübendorf, Switzerland

$5 \quad$ b: Department of Structural Engineering, Norwegian University of Science and Technology,

6 Trondheim, Norway.

7 Corresponding author: Barbara Lothenbach; E-mail: Barbara.Lothenbach@empa.ch;

Tel.: +4158765 4788

Abstract:

Magnesium potassium phosphate (MKP) cements show fast setting and high early strength. MKP cements harden in the presence of water due to the reaction of potassium dihydrogen phosphate $\left(\mathrm{KH}_{2} \mathrm{PO}_{4}\right)$ with magnesia $(\mathrm{MgO})$ resulting in the formation of mainly K-struvite $\left(\mathrm{MgKPO}_{4} \cdot 6 \mathrm{H}_{2} \mathrm{O}\right)$.

Other hydrates, newberyite, phosphorrösslerite, cattiite and $\mathrm{Mg}_{2} \mathrm{KH}\left(\mathrm{PO}_{4}\right)_{2} \cdot 15 \mathrm{H}_{2} \mathrm{O}$ are formed as intermediate phases during hydration. This paper presents a consistent thermodynamic database for magnesium phosphate hydrates based on solubility measurements for newberyite, phosphorrösslerite, farringtonite, $\mathrm{Mg}_{3}\left(\mathrm{PO}_{4}\right)_{2} \cdot 4 \mathrm{H}_{2} \mathrm{O}$, bobierrite, cattiite, $\mathrm{K}$-struvite, $\mathrm{KMgPO}_{4} \cdot \mathrm{H}_{2} \mathrm{O}$, and $\mathrm{Mg}_{2} \mathrm{KH}\left(\mathrm{PO}_{4}\right)_{2} \cdot 15 \mathrm{H}_{2} \mathrm{O}$ carried at different temperature.

It was found that the formation of the different hydrates is strongly influenced by $\mathrm{pH}$. Newberyite, phosphorrösslerite and $\mathrm{Mg}_{2} \mathrm{KH}\left(\mathrm{PO}_{4}\right)_{2} \cdot 15 \mathrm{H}_{2} \mathrm{O}$ are intermediate phases, which form at low $\mathrm{pH}$ as typical at very early hydration times. As $\mathrm{pH}$ rises, bobierrite and cattiite may be stabilised, while at high $\mathrm{pH}$ K-struvite forms. The phases formed are also strongly influenced by the temperature. 


\section{Introduction}

Magnesium potassium phosphate (MKP) cement hardens in the presence of water through the reaction between potassium dihydrogen phosphate $\left(\mathrm{KH}_{2} \mathrm{PO}_{4}\right)$ and magnesia $(\mathrm{MgO})$. Compared to Portland cement, MKP cement has different advantages such as fast setting (Qiao et al., 2010; Wagh, 2004), high early strength (Qiao et al., 2010; Xu et al., 2017), strong bonding with concrete substrate (Qiao et al., 2010; Xu et al., 2015), low pH (Wagh, 2004; Walling and Provis, 2016), and good biocompatibility (Wang et al., 2013) such that MKP cement is used as rehabilitation materials (Ding and Li, 2005; Lee et al., 2017; Qiao et al., 2010; Wagh, 2004; Xu et al., 2017; Xu et al., 2015), as solidification/stabilization agent for low-level nuclear wastes and other wastes containing heavy metals (Buj et al., 2009; Buj et al., 2010; Wagh, 2004; Walling and Provis, 2016), and as bio-material (Wang et al., 2013).

The main reaction of hydrating MKP cement can be described as $\mathrm{MgO}+\mathrm{KH}_{2} \mathrm{PO}_{4}+5 \mathrm{H}_{2} \mathrm{O} \rightarrow$ $\mathrm{MgKPO}_{4} \cdot 6 \mathrm{H}_{2} \mathrm{O}$ (K-struvite). Thus magnesium potassium hexahydrate $\left(\mathrm{MgKPO}_{4} \cdot 6 \mathrm{H}_{2} \mathrm{O}, \mathrm{K}\right.$-struvite) is the main hydrate formed providing mechanical strength. However, different experimental studies (Chau et al., 2012; Lahalle et al., 2016; Le Rouzic et al., 2017a) showed that a number of other hydrates, such as $\mathrm{MgHPO}_{4} \cdot 3 \mathrm{H}_{2} \mathrm{O}$ (newberyite) (Le Rouzic et al., 2017a), $\mathrm{MgHPO}_{4} \cdot 7 \mathrm{H}_{2} \mathrm{O}$ (phosphorrösslerite) (Chau et al., 2012), $\mathrm{Mg}_{3}\left(\mathrm{PO}_{4}\right)_{2} \cdot 8 \mathrm{H}_{2} \mathrm{O}$ (bobierrite), $\mathrm{Mg}_{3}\left(\mathrm{PO}_{4}\right)_{2} \cdot 22 \mathrm{H}_{2} \mathrm{O}$ (cattiite) (Lahalle et al., 2016), and $\mathrm{Mg}_{2} \mathrm{KH}\left(\mathrm{PO}_{4}\right)_{2} \cdot 15 \mathrm{H}_{2} \mathrm{O}$ (Chau et al., 2012; Lahalle et al., 2016) are formed as well during hydration. The kind of the hydrates formed is influenced by the availability of water, magnesium, phosphate, potassium ions and $\mathrm{pH}$ value. (Le Rouzic et al., 2017b) reported that K-struvite in MKP cement pastes with waterto-cement $(\mathrm{w} / \mathrm{c})$ ratio of 0.2 had a needle-like shape at a magnesium-to-phosphate $\left(\mathrm{Mg} / \mathrm{PO}_{4}\right)$ molar ratio of 1 , but that it had a platelet-like shape at $\mathrm{Mg} / \mathrm{PO}_{4}=5$. The type of hydrate formed and its morphology are crucial for the cement properties, such as efflorescence, strength and volume stability.

Although MKP cement is a simple quaternary system of $\mathrm{MgO}-\mathrm{KH}_{2} \mathrm{PO}_{4}-\mathrm{H}_{2} \mathrm{O}$, its optimum design is still challenging due to the insufficient understanding of the reaction mechanisms. $\mathrm{Mg} / \mathrm{PO}_{4}$ molar ratio and $\mathrm{w} / \mathrm{c}$ ratio are the two important factors controlling $\mathrm{pH}$ of the cement system, reaction path (Chau et al., 2012; Lahalle et al., 2016; Le Rouzic et al., 2017a; Xu et al., 2018a), microstructure (Le Rouzic et 
al., 2017b; Ma et al., 2014a; Ma et al., 2014b; Xu et al., 2015), and thus performance (Le Rouzic et al., 2017b; Lee et al., 2017; Ma et al., 2014b; Qiao et al., 2010; Xu et al., 2017; Xu et al., 2015). A low $\mathrm{Mg} / \mathrm{PO}_{4}$ molar ratio (<4) MKP cement is preferably used as waste solidification agent (Buj et al., 2009; Buj et al., 2010; Gardner et al., 2015a; Gardner et al., 2015b; Lahalle et al., 2016; Le Rouzic et al., 2017b; Walling and Provis, 2016), as a lower $\mathrm{Mg} / \mathrm{PO}_{4}$ molar ratios decrease $\mathrm{pH}$ values, which is favourable for immobilizing metallic wastes (Coumes et al., 2014; Covill et al., 2011; Gardner et al., 2015b; Walling and Provis, 2016) such as aluminium, magnesium, and uranium containing nuclear wastes. However, some MKP cement-based materials with low $\mathrm{Mg} / \mathrm{PO}_{4}$ molar ratio showed problems such as efflorescence, strength decrease at later ages and expansion due to the formation of intermediate phases (Chau et al., 2012; Le Rouzic et al., 2017a; Le Rouzic et al., 2017b; Xu et al., 2019). A high $\mathrm{Mg} / \mathrm{PO}_{4}$ molar ratio $(\geq 4)$ has been more frequently used for producing MKP cement-based materials for infrastructure applications (Lee et al., 2017; Li et al., 2017; Ma and Xu, 2017; Qiao et al., 2010; Xu et al., 2018a; Xu et al., 2018b; Xu et al., 2017; Xu et al., 2019; Xu et al., 2015; Yue et al., 2014). Optimum $\mathrm{Mg} / \mathrm{PO}_{4}$ molar ratio that contributes to high mechanical strength was reported to be in the range of $4-8$ (Ma and $\mathrm{Xu}, 2017$; Xu et al., 2019), depending on the exact w/c ratio used. The use of high $\mathrm{Mg} / \mathrm{PO}_{4}$ molar ratio simplifies the reaction path such that no or very little intermediate hydrates were formed (Chau et al., 2012; Lahalle et al., 2016; Le Rouzic et al., 2017a; Le Rouzic et al., 2017b; $\mathrm{Xu}$ et al., 2018a; Xu et al., 2019). Furthermore, the cement reaction path is affected by the w/c ratio. The formation of intermediate hydrates was observed at a high w/c of 5 ; at a low w/c of 0.5 and below their formation was avoided (Xu et al., 2018a; Xu et al., 2019). Currently the understanding of the reaction mechanism of hydrating MKP cement system is still insufficient, which makes optimising material design difficult and material performance over time hard to predict. Therefore, instruments to efficiently and accurately investigate the complexity of hydrating MKP cement are of great importance.

Thermodynamic models have been developed over the past decades to better understand and investigate hydrating cements and have been applied successfully to different cements such as Portland cement (Lothenbach and Winnefeld, 2006), blended Portland cement (Lothenbach et al., 2008; Lothenbach et al., 2011), calcium sulfoaluminate cement (Winnefeld and Lothenbach, 2010), or alkaliactivated cement (Ben Haha et al., 2011). The reliability of such model predictions relies on the accuracy 
and completeness of the underlying thermodynamic database. While during the last past two decades, significant effort has been made to complete thermodynamic data for calcium, silicon and aluminium based cements (Dilnesa et al., 2014; Lothenbach et al., 2019; Lothenbach et al., 2008; Lothenbach et al., 2012; Lothenbach and Winnefeld, 2006; Matschei et al., 2007; Myers et al., 2015; Nied et al., 2016), much less effort had been focussed on magnesium phosphate cements. Only limited measured thermodynamic data are available for some magnesium phosphate hydrates: newberyite, cattiite, Kstruvite and bobierrite (Babić-Ivančić et al., 2006; Racz and Soper, 1968; Taylor et al., 1963a; Taylor et al., 1963b), while for other phosphate hydrates, such as $\mathrm{Mg}_{3}\left(\mathrm{PO}_{4}\right)_{2} \cdot 4 \mathrm{H}_{2} \mathrm{O}$ or $\mathrm{Mg}_{2} \mathrm{KH}\left(\mathrm{PO}_{4}\right)_{2} \cdot 15 \mathrm{H}_{2} \mathrm{O}$, no measured solubility data have been published. Thermodynamic data for magnesium phosphates have also been estimated from the free energy and enthalpy of the oxides (Chau et al., 2012; La Iglesia, 2009; Zhang et al., 2017), a procedure which can lead to accurate estimations in some cases, but can deviate in the order of several $10 \mathrm{of} \mathrm{kJ} / \mathrm{mol}$ to the data derived from solubility measurements (Lothenbach et al., 2017), which makes predictions of solubility and relative stability based on such data difficult. This lack of a complete and reliable thermodynamic database for magnesium (potassium) phosphate hydrates prevents the efficient use of thermodynamic models to predict the effect of varying cement composition, temperature and time in such systems. Thus, the present paper builds a consistent thermodynamic database for magnesium phosphate hydrates based on solubility measurements for newberyite, phosphorrösslerite, $\mathrm{KMgPO}_{4} \cdot \mathrm{H}_{2} \mathrm{O}, \mathrm{K}$-struvite, $\mathrm{Mg}_{2} \mathrm{KH}\left(\mathrm{PO}_{4}\right)_{2} \cdot 15 \mathrm{H}_{2} \mathrm{O}$, farringtonite $\left(\mathrm{Mg}_{3}\left(\mathrm{PO}_{4}\right)_{2}\right)$, $\mathrm{Mg}_{3}\left(\mathrm{PO}_{4}\right)_{2} \cdot 4 \mathrm{H}_{2} \mathrm{O}$, bobierrite, and cattiite, carried out at different temperatures and a critical review of existing thermodynamic data and solubility measurements from literature. Finally the derived thermodynamic data are used to model the effect of $\mathrm{Mg} / \mathrm{PO}_{4}$ ratio, of the water to cement ratio, of $\mathrm{pH}$ values and of temperature on the stable phases.

\section{Materials and methods}

\subsection{Materials}

All the starting materials used in this study were magnesia ( $\mathrm{MgO}, 97 \%$, Emsure ${ }^{\circledR}$ ), magnesium chloride $\left(\mathrm{MgCl}_{2}, \geq 98 \%\right.$, Sigma $\left.{ }^{\circledR}\right)$, magnesium acetate tetrahydrate $\left(\mathrm{Mg}\left(\mathrm{CH}_{3} \mathrm{COO}\right)_{2} \cdot 4 \mathrm{H}_{2} \mathrm{O}, 99.5\right.$ - 
$102.0 \%$, Esure $\left.{ }^{\circledR}\right)$, magnesium sulfate heptahydrate $\left(\mathrm{MgSO}_{4} \cdot 7 \mathrm{H}_{2} \mathrm{O}, \geq 99.5 \%\right.$, Emsure $\left.{ }^{\circledR}\right)$, potassium dihydrogen phosphate $\left(\mathrm{KH}_{2} \mathrm{PO}_{4}, 99.5-100.5 \%\right.$, Sigma-Aldrich $\left.{ }^{\circledR}\right)$, potassium phosphate dibasic trihydrate $\left[\mathrm{K}_{2} \mathrm{HPO}_{4} \cdot 3 \mathrm{H}_{2} \mathrm{O}, \geq 99.0 \%\right.$, Sigma-Aldrich $\left.{ }^{\circledR}\right]$, potassium hydroxide $(\mathrm{KOH}, \geq 85 \%$, HoneywellFluka $\left.{ }^{\circledR}\right)$, sodium phosphate dibasic dodecahydrate $\left(\mathrm{Na}_{2} \mathrm{HPO}_{4} \cdot 12 \mathrm{H}_{2} \mathrm{O}, 98.5-101 \%\right.$, Sigma-Aldrich $\left.{ }^{\circledR}\right)$, and calcium nitrate tetrahydrate $\left(\mathrm{Ca}\left(\mathrm{NO}_{3}\right)_{2} \cdot 4 \mathrm{H}_{2} \mathrm{O}, 99 \%\right.$, Sigma-Aldrich $\left.{ }^{\circledR}\right)$.

Magnesium phosphate hydrates were precipitated in solution as detailed in Table 1-1; after different equilibration times the suspensions were filtrated as detailed below and the composition of the solid and liquid phase was investigated. A fraction of the dried solids was re-dissolved in Milli-Q water and equilibrated at different temperatures and times, as summarised in Table 1-2. In order to further study the influence of several important factors, such as $\mathrm{pH}, \mathrm{Mg} / \mathrm{PO}_{4}$ molar ratio, water-to-solid (w/s) ratio and temperature on the formation of magnesium phosphate hydrates, three systems of $\mathrm{MgCl}_{2}-\mathrm{KH}_{2} \mathrm{PO}_{4^{-}}$ $\mathrm{H}_{2} \mathrm{O}, \mathrm{MgO}-\mathrm{KH}_{2} \mathrm{PO}_{4}-\mathrm{H}_{2} \mathrm{O}$ and $\mathrm{MgSO}_{4}-\mathrm{KH}_{2} \mathrm{PO}_{4}-\mathrm{H}_{2} \mathrm{O}$ were prepared as listed in Table 1-3.

Table 1: Materials and mix proportions used to prepare magnesium phosphate solids (in $[\mathrm{g} / 100 \mathrm{~g}$ solution]).

1: Synthesis of pure magnesium phosphate hydrates

\begin{tabular}{|c|c|c|c|c|c|c|c|c|c|c|}
\hline Name & composition & $\mathrm{MgCl}_{2}$ & $\operatorname{Mg}(\mathrm{ac}) 2^{\mathrm{a}}$ & $\begin{array}{l}\text { Mg-sulf }{ }^{\mathrm{a}} \\
---[\mathrm{g} / 100 \\
\end{array}$ & $\begin{array}{l}\mathrm{NaH}_{2} \mathrm{PO}_{4}{ }^{\mathrm{a}} \\
\mathrm{g} \text { solution] }\end{array}$ & $\begin{array}{l}\mathrm{KH}_{2} \mathrm{PO}_{4} \\
---\end{array}$ & $\begin{array}{l}\mathrm{KOH} \\
{[\mathrm{mM}]}\end{array}$ & $\begin{array}{l}\text { Ca-nit. }^{\text {a }} \\
\text { [g] }\end{array}$ & $\begin{array}{l}\text { Temp } \\
{\left[{ }^{\circ} \mathrm{C}\right]}\end{array}$ & Time \\
\hline $\mathrm{New}^{\mathrm{b}}$ & $\mathrm{MgHPO}_{4} \cdot 7 \mathrm{H}_{2} \mathrm{O}$ & 0.48 & - & - & - & 0.68 & 50 & - & 20 & 60 \\
\hline Phos & $\mathrm{MgHPO}_{4} \cdot 3 \mathrm{H}_{2} \mathrm{O}$ & - & 14.39 & - & - & 8.40 & - & - & 20 & $5,30 \mathrm{~min}, 1 \mathrm{~h}, 1$ \\
\hline K-str & $\mathrm{MgKPO}_{4} \cdot 6 \mathrm{H}_{2} \mathrm{O}$ & 5.00 & - & - & & 25.00 & c & - & 20 & 14 \\
\hline H15 & $\mathrm{Mg}_{2} \mathrm{KH}\left(\mathrm{PO}_{4}\right)_{2} \cdot 15 \mathrm{H}_{2} \mathrm{C}$ & ${ }_{2} \mathrm{O}-$ & - & 2.91 & - & $2.69^{d}$ & - & - & 20 & 28 \\
\hline $\mathrm{MO}^{\mathrm{e}}$ & $\mathrm{Mg}_{3}\left(\mathrm{PO}_{4}\right)_{2} \cdot 4 \mathrm{H}_{2} \mathrm{O}$ & - & - & 0.55 & 0.53 & - & - & - & 90 & 2.5 \\
\hline Bob & $\mathrm{Mg}_{3}\left(\mathrm{PO}_{4}\right)_{2} \cdot 8 \mathrm{H}_{2} \mathrm{O}$ & - & - & 0.54 & 0.55 & - & - & 0.0054 & 90 & 2.5 \\
\hline Cat_5 & $\mathrm{Mg}_{3}\left(\mathrm{PO}_{4}\right)_{2} \cdot 22 \mathrm{H}_{2} \mathrm{O}$ & - & - & 0.66 & 0.64 & - & - & - & 5 & $50,140 \mathrm{~d}$ \\
\hline Cat $40^{\mathrm{f}}$ & $\mathrm{Mg}_{3}\left(\mathrm{PO}_{4}\right)_{2} \cdot 22 \mathrm{H}_{2} \mathrm{O}$ & - & - & 0.66 & 0.64 & - & - & - & $5 / 40$ & $30 \mathrm{~d}$ \\
\hline
\end{tabular}

2: Dissolution and equilibration of magnesium phosphate hydrates at different temperature and time

\begin{tabular}{lllccr}
\hline Name & \multicolumn{2}{c}{ Composition } & $\begin{array}{c}\text { Weight } \\
{[\mathrm{g} / 100 \mathrm{~g} \text { MilliQ water }]}\end{array}$ & $\begin{array}{c}\text { Temperature } \\
{\left[{ }^{\circ} \mathrm{C}\right]}\end{array}$ & $\begin{array}{r}\text { Time } \\
{[\mathrm{d}]}\end{array}$ \\
\hline K-str & K-struvite & $\mathrm{MgKPO}_{4} \cdot 6 \mathrm{H}_{2} \mathrm{O}$ & 1.00 & $20,40,80$ & 30 \\
Bob & Bobierrite & $\mathrm{Mg}_{3}\left(\mathrm{PO}_{4}\right)_{2} \cdot 8 \mathrm{H}_{2} \mathrm{O}$ & 1.00 & $20,40,80$ & 14 \\
Cat & Cattiite & $\mathrm{Mg}_{3}\left(\mathrm{PO}_{4}\right)_{2} \cdot 22 \mathrm{H}_{2} \mathrm{O}$ & 0.19 & $20,40,80$ & 30 \\
Cat_D & Cattiite dried & $\mathrm{Mg}_{3}\left(\mathrm{PO}_{4}\right)_{2}$ & 0.50 & $20,40,80$ & 30
\end{tabular}

3: Influence of $\mathrm{pH}, \mathrm{Mg} / \mathrm{PO}_{4}$ molar ratio, w/s on the formation of magnesium phosphate hydrates

\begin{tabular}{|c|c|c|c|c|c|c|c|}
\hline Name & $\begin{array}{r}\mathrm{Mg} / \mathrm{PO}_{4} \\
{[\mathrm{~mol} / \mathrm{mol}}\end{array}$ & $\begin{array}{r}\mathrm{w} / \mathrm{s} \\
{[\mathrm{g} / \mathrm{g}]}\end{array}$ & $\begin{array}{l}\text { K conc. } \\
{[\mathrm{mM}]}\end{array}$ & $\begin{array}{cccc}\mathrm{KH}_{2} \mathrm{PO}_{4} & \mathrm{MgO} & \mathrm{MgCl}_{2} & \mathrm{MgSO}_{4} \cdot 7 \mathrm{H}_{2} \mathrm{O}^{\mathrm{h}} \\
& \text { added in [g/100g solution] }\end{array}$ & $\begin{array}{l}\mathrm{KOH} \\
{[\mathrm{mM}]}\end{array}$ & $\begin{array}{l}\text { Temp. } \\
{\left[{ }^{\circ} \mathrm{C}\right]}\end{array}$ & $\begin{array}{l}\text { Time } \\
{[\mathrm{d}]}\end{array}$ \\
\hline
\end{tabular}

a): Variation pH, samples with chloride and $\mathrm{KOH}$ 


\begin{tabular}{|c|c|c|c|c|c|c|c|c|c|c|}
\hline 1443 & 1.0 & 43 & 150 & 1.36 & - & 0.952 & - & 50 & 20 & 60 \\
\hline $1 \_86 \mathrm{~L}^{\mathrm{a}}$ & 1.0 & 86 & 110 & 0.68 & - & 0.476 & - & 50 & 20 & 60,120 \\
\hline $1 \_86 \mathrm{M}$ & 1.0 & 86 & 124 & 0.68 & - & 0.476 & - & 74 & 20 & 60 \\
\hline $1 \_86 \mathrm{H}$ & 1.0 & 86 & 150 & 0.68 & - & 0.476 & - & 100 & 20 & 60,750 \\
\hline \multicolumn{11}{|c|}{ b): $\mathrm{Mg} / \mathrm{PO}_{4}:$ Variation $\mathrm{Mg} / \mathrm{PO}_{4}$ at low and high w/s } \\
\hline $05 \_5$ & 0.5 & 5 & 1.282 & 17.44 & 2.56 & - & - & - & 20 & 75,480 \\
\hline $05 \_10$ & 0.5 & 10 & 0.641 & 8.72 & 1.28 & - & - & - & 20 & 75,480 \\
\hline \multirow[t]{2}{*}{$05-64$} & 0.5 & 64 & 0.100 & 1.36 & 0.20 & - & - & - & 20 & 60,750 \\
\hline & 0.5 & 64 & 0.100 & 1.36 & 0.20 & - & - & - & $5,50,80$ & 30 \\
\hline $06 \_62$ & 0.6 & 62 & 0.100 & 1.36 & 0.24 & - & - & - & 20 & 60 \\
\hline 07 61 & 0.7 & 61 & 0.100 & 1.36 & 0.28 & - & - & - & 20 & 60,480 \\
\hline $08 \_5$ & 0.8 & 5 & 1.190 & 16.19 & 3.81 & - & - & - & 20 & 75 \\
\hline $08 \_10$ & 0.8 & 10 & 0.595 & 8.10 & 1.91 & - & - & - & 20 & 75 \\
\hline $08 \_59$ & 0.8 & 59 & 0.100 & 1.36 & 0.32 & - & - & - & 20 & 60 \\
\hline $1 \_5$ & 1.0 & 5 & 1.136 & 15.46 & 4.54 & - & - & - & 20 & 75,480 \\
\hline 1_10 & 1.0 & 10 & 0.568 & 7.73 & 2.27 & - & - & - & 20 & 75,480 \\
\hline \multirow[t]{3}{*}{ 1_57 } & 1.0 & 57 & 0.100 & 1.36 & 0.40 & - & - & - & 20 & 60,750 \\
\hline & 1.0 & 57 & 0.100 & 1.36 & 0.40 & - & - & - & 5,50 & 30,360 \\
\hline & 1.0 & 57 & 0.100 & 1.36 & 0.40 & - & - & - & 80 & 30 \\
\hline $1.5 \_51$ & 1.5 & 51 & 0.100 & 1.36 & 0.60 & - & - & - & 20 & 60,480 \\
\hline \multicolumn{11}{|c|}{ c): $w / s:$ Variation $w / s$ prepared from magnesium sulfate } \\
\hline $1 \_7 \mathrm{~S}$ & 1.0 & 6.8 & $>800$ & 6.8 & - & - & 12.32 & $*$ & 20 & 30 \\
\hline $1 \_10 \mathrm{~S}$ & 1.0 & 10 & 249.8 & 3.4 & - & - & 6.16 & - & 20 & 760 \\
\hline $1 \_15 \mathrm{~S}$ & 1.0 & 15 & $>400$ & 3.4 & - & - & 6.17 & $*$ & 20 & 30 \\
\hline 1_76S & 1.0 & 76 & $>100$ & 0.68 & - & - & 1.25 & * & 20 & 30 \\
\hline $1.3-10 \mathrm{~S}^{\mathrm{c}}$ & 1.3 & 10 & 381.72 & $4.36^{c}$ & - & - & 6.16 & - & 20 & 760 \\
\hline
\end{tabular}

a $\mathrm{Mg}(\mathrm{ac})_{2}: \mathrm{Mg}\left(\mathrm{CH}_{3} \mathrm{COO}\right)_{2} \cdot 4 \mathrm{H}_{2} \mathrm{O} ; \mathrm{Mg}$-sulf: $\mathrm{MgSO}_{4} \cdot 7 \mathrm{H}_{2} \mathrm{O} ; \mathrm{NaH}_{2} \mathrm{PO}_{4}: \mathrm{NaH}_{2} \mathrm{PO}_{4} \cdot 12 \mathrm{H}_{2} \mathrm{O}$. ${ }^{\mathrm{b}}$ New and 1_86L have identical starting compositions. ${ }^{\mathrm{c}}$ Amount of $\mathrm{KOH}$ was not recorded. ${ }^{\mathrm{d}} \mathrm{K}_{2} \mathrm{HPO}_{4} \cdot 3 \mathrm{H}_{2} \mathrm{O}$. ${ }^{\mathrm{e}}$ Filtered solution was not analysed by IC; ${ }^{\mathrm{f}}$

Cat 5 suspension directly re-equilibrated at $40^{\circ} \mathrm{C}$ without filtration, washing or drying; ${ }^{\mathrm{g}} \mathrm{Mg}_{3}\left(\mathrm{PO}_{4}\right)_{2}$ was obtained by calcinating cattiite at $300^{\circ} \mathrm{C}$ for $4 \mathrm{~h} .{ }^{\mathrm{h}} \mathrm{H}_{2} \mathrm{O}$ in $\mathrm{MgSO}_{4} \cdot 7 \mathrm{H}_{2} \mathrm{O}$ considered as water to calculate $\mathrm{w} / \mathrm{s}$.

\subsection{Methods}

After equilibration, the solid and liquid phases in each sample mixture were separated by vacuum filtration through $0.45 \mu \mathrm{m}$ Nylon filters. The obtained solids were first rinsed by Milli-Q water, then soaked in isopropanol for $10 \mathrm{~min}$ to remove the remaining liquid, filtered again and rinsed with diethyl ether to remove residual isopropanol following the procedure outlined in (Snellings et al., 2018; Winnefeld et al., 2016). The solids were further dried in an oven at $40{ }^{\circ} \mathrm{C}$ for $5 \mathrm{~min}$ to evaporate any remaining organic solvents; the applied relatively mild drying procedure together with a rapid analysis of the solids generally within a day, allowed to stabilise also the water rich hydrates phosphorrösslerite $\left(\mathrm{MgHPO}_{4} \cdot 7 \mathrm{H}_{2} \mathrm{O}\right), \mathrm{Mg}_{2} \mathrm{KH}\left(\mathrm{PO}_{4}\right)_{2} \cdot 15 \mathrm{H}_{2} \mathrm{O}$ and cattiite $\left(\mathrm{Mg}_{3}\left(\mathrm{PO}_{4}\right) 2 \cdot 22 \mathrm{H}_{2} \mathrm{O}\right)$. The mineralogical composition of the solid samples was determined by X-ray diffraction (XRD, PANalytical X'Pert Pro) in a $\theta-\theta$ configuration using $\mathrm{CoK}_{\alpha}$ radiation. A summary of the XRD references patterns used is summarised in the Supplementary Material. 
Thermogravimetric analysis was performed using a Mettler Toledo TGA/SDTA 851e with a heating rate of $10{ }^{\circ} \mathrm{C} / \mathrm{min}$ from 30 to $600{ }^{\circ} \mathrm{C}$ and $\mathrm{N}_{2}$ as protective gas. Fourier transformation infrared spectroscopy (FT-IR) spectra were recorded using a Bruker Tensor 27 FT-IR spectrometer in a wavenumber range from 4000 to $300 \mathrm{~cm}^{-1}$. Raman spectra were acquired using a Raman Bruker Senterra microscope equipped with a Peltier-cooled CCD detector and operated with the software Opus 6.5. Scanning electron microscopy (SEM, ESM Quanta FEG 650) was done in high vacuum mode with an accelerating voltage of $10-15 \mathrm{kV}$ and a spot size of $2.5-4$. The powder samples were applied to carbon tape first, and coated with $20 \mathrm{~nm}$ carbon.

The filtered liquid was separated into two parts. The $\mathrm{pH}$ measurements were carried out immediately after filtration on a part of the filtered liquid using a Knick pH meter (pH-Meter 766) with a Knick SE100 electrode. The $\mathrm{pH}$ electrode was calibrated with $\mathrm{pH}$ buffers $(4,7,9$ and 12) before measurement. The second part of the filtered liquid was diluted by Milli-Q water for ion chromatography (IC) analysis. Concentrations of magnesium, potassium, calcium, sodium, phosphate, chloride and sulfate were quantified using a Dionex DP series ICS-3000 ion chromatograph. Standards from 0.1 to $50 \mathrm{mg} / \mathrm{L}$ were used.

\subsection{Thermodynamic modelling}

Thermodynamic modelling was carried out using the Gibbs free energy minimization program GEMS (Kulik et al., 2013; Wagner et al., 2012). GEMS is a broad-purpose geochemical modelling code which computes equilibrium phase assemblage and speciation in a complex chemical system from its total bulk composition. Thermodynamic data for aqueous species, as well as for many solids, were taken from the GEMS-PSI thermodynamic database (Thoenen et al., 2014; Thoenen and Kulik, 2003). The constants given in the original PSI thermodynamic database (Thoenen et al., 2014) have been converted into standard molar Gibbs energies and merged with the slop98.dat database as documented in (Johnson et al., 1992). For aqueous species, this dataset includes the HKF (Helgeson-Kirkham-Flowers) equation of state which is used to calculate temperature and pressure corrections up to $1000^{\circ} \mathrm{C}$ and $5 \mathrm{kbar}$.

The measured concentrations in the solution were used to calculate ion activity and solubility products for the different magnesium phosphate hydrates. The solubility of the different solids, if 
present, can be calculated from the same measured solution composition; in a system with $\mathrm{Mg}, \mathrm{K}$, phosphate and water the maximum number of solids that thermodynamically can be in equilibrium is limited to 3 solid phases by the Gibbs phase rule. In general, all measured data where the solid was observed, were used to calculate solubility products. The activity of a species $\mathrm{i},\{\mathrm{i}\}$, was calculated with GEMS from the measured concentrations considering the formation of aqueous complexes by $\{\mathrm{i}\}=$ $\gamma_{i} \cdot m_{i}$, where $\gamma_{i}$ is the activity coefficient and $m_{i}$ the concentration in mol/kg $\mathrm{H}_{2} \mathrm{O}$. The activity coefficients of the aqueous species $\gamma$ were computed with the built-in extended Debye-Hückel equation with common ion-size parameter $a_{i}$ of $3.67 \AA$ for $\mathrm{KOH}$ solutions and common third parameter $b_{y}$ according to Eq. (1)

$$
\log \gamma_{i}=\frac{-A_{y} z_{i}^{2} \sqrt{I}}{1+B_{y} a_{i} \sqrt{I}}+b_{y} I
$$

where $\mathrm{z}_{i}$ denotes the charge of species $i$, I the effective molar ionic strength, $b_{y}$ is a semi-empirical parameter $\left(\sim 0.123\right.$ for $\mathrm{KOH}$ electrolyte at $\left.25^{\circ} \mathrm{C}\right)$, and $\mathrm{A}_{y}$ and $\mathrm{B}_{y}$ are $\mathrm{P}, \mathrm{T}$-dependent coefficients. This activity correction is applicable up to approx. $1 \mathrm{M}$ ionic strength (Merkel and Planer-Friederich, 2008). Thus experimental data with an ionic strength above $1 \mathrm{M}$ were not considered for the calculation of solubility products.

The thermodynamic data for solids at temperatures other than $25^{\circ} \mathrm{C}$ were calculated using the temperature dependence of the apparent Gibbs free energy of formation from element $\Delta_{\mathrm{a}} \mathrm{G}^{\circ}$ according to Eq.(2):

$$
\begin{aligned}
\Delta_{a} G_{T}^{o} & =\Delta_{f} G_{T_{0}}^{o}-S_{T_{0}}^{o}\left(T-T_{0}\right)-\int_{T_{0}}^{T} \int_{T_{0}}^{T} \frac{C_{p}^{o}}{T} d T d T \\
& =\Delta_{f} G_{T_{0}}^{o}-S_{T_{0}}^{o}\left(T-T_{0}\right)-a_{0}\left(T \ln \frac{T}{T_{0}}-T+T_{0}\right)-0.5 a_{1}\left(T-T_{0}\right)^{2}-a_{2} \frac{\left(T-T_{0}\right)^{2}}{2 T \cdot T_{0}{ }^{2}}-a_{3} \frac{2\left(\sqrt{T}-\sqrt{T_{0}}\right)^{2}}{\sqrt{T_{0}}}
\end{aligned}
$$

where $\mathrm{a}_{0}, \mathrm{a}_{1}, \mathrm{a}_{2}$, and $\mathrm{a}_{3}$ are the empirical coefficients of the heat capacity equation $\mathrm{C}_{\mathrm{p}}^{\circ}=\mathrm{a}_{0}+\mathrm{a}_{1} \mathrm{~T}+\mathrm{a}_{2} \mathrm{~T}^{-2}$ $+\mathrm{a}_{3} \mathrm{~T}^{-0.5}$ and $\mathrm{T}_{0}$ is the reference temperature $(298.15 \mathrm{~K})$. The apparent Gibbs free energy of formation $\Delta_{\mathrm{a}} \mathrm{G}^{\circ}$ T0 refers to the free energies of the elements at $298 \mathrm{~K}$. The above calculation is built into the GEMSPSI code. A more detailed description of the derivation of the dependence of temperature of the Gibbs 
energy is given in the online documentation of GEMS, in (Kulik, 2002) or in (Anderson and Crerar, 1993).

Where no measured entropy or heat capacity data were available, they were estimated from structurally similar magnesium phosphates following the procedure outlined in (Helgeson et al., 1978). The entropy of a phase A was calculated from the entropy of the solids B and C assuming $\Delta \mathrm{S}_{\mathrm{r}}=0$ considering the molar volume according to Eq. 62 in (Helgeson et al., 1978): $\mathrm{S}_{\mathrm{A}}=\left(\mathrm{S}_{\mathrm{B}}+\mathrm{S}_{\mathrm{C}}\right) \bullet\left(\mathrm{V}^{\circ}{ }_{\mathrm{B}}+\mathrm{V}^{\circ}{ }_{\mathrm{C}}+\mathrm{V}^{\circ}{ }_{\mathrm{A}}\right) / 2 /\left(\mathrm{V}^{\circ}{ }_{\mathrm{B}}\right.$ $\left.+\mathrm{V}^{\circ} \mathrm{C}\right)$ ). The $\mathrm{C}_{\mathrm{p}}$ was calculated directly from the heat capacity assuming $\Delta \mathrm{C}_{\mathrm{p}, \mathrm{r}}=0$ following Eq. 78 in (Helgeson et al., 1978).

The standard PSI/Nagra thermodynamic database in GEMS (Thoenen et al., 2014; Thoenen and Kulik, 2003) contains data for the deprotonation of phosphoric acid and pyrophosphoric acid (see Supplementary Material), but no data to account for the complex formation of alkali and earth alkali ions with aqueous phosphate species. Thus the aqueous data were completed with data for aqueous phosphate complexes, where possible from experimental data, and else with data from the comprehensive review of (Turner et al., 1981) as compiled in Table S.1 in the Supplementary Material).

\section{Solubility of magnesium (potassium) phosphate phases}

The analysis of the equilibrated solutions at $20^{\circ} \mathrm{C}$ as well as XRD, TGA, FT-IR, Raman and SEM observations of newberyite, $\mathrm{K}$-struvite, $\mathrm{Mg}_{2} \mathrm{KH}\left(\mathrm{PO}_{4}\right)_{2} \cdot 15 \mathrm{H}_{2} \mathrm{O}$, cattiite, bobierrite and $\mathrm{Mg}_{3}\left(\mathrm{PO}_{4}\right)_{2} \cdot 4 \mathrm{H}_{2} \mathrm{O}$ are presented. Details on the preparation methods are summarised in Table 1, the measured data under different conditions and equilibration times are summarized in Table 2. The results are discussed in detail in the following sections.

Table 2: Measured concentrations, $\mathrm{pH}$ values and calculated ion activity products for the different magnesium phosphate solid precipitated from oversaturation at $20^{\circ} \mathrm{C}$. Ion activity products (IAP) for those solids, which were observed in the dried samples are plotted, in bold; only those IAP have been used to calculate solubility products.

\begin{tabular}{|c|c|c|c|c|c|c|c|c|c|c|}
\hline $\mathrm{pH}^{*}$ & $\mathrm{Mg}$ & K & $\begin{array}{l}\mathrm{P} \text { acetate } \\
\mathrm{mM}] \text {--- }\end{array}$ & Phos & $\begin{array}{r}\text { New } \\
---1\end{array}$ & $\begin{array}{l}\text { MO4 } \\
\text { activi }\end{array}$ & $\begin{array}{l}\text { Cat } \\
\text { oroduc }\end{array}$ & 15 & K-str & $\begin{array}{l}\text { solids** } \\
\text { observed }\end{array}$ \\
\hline
\end{tabular}




$\begin{array}{llllllllllll}5 \mathrm{~min} & 5.12 & 269 & 564 & 258 & 1230 & \mathbf{- 1 7 . 0 6}-17.00 & -25.29 & -25.55 & -29.48 & -12.28 & \text { Phos } \\ 30 \mathrm{~min} & 5.14 & 267 & 551 & 221 & 1230 & \mathbf{- 1 7 . 0 9}-17.03 & -25.27 & -25.53 & -29.51 & -12.29 & \text { Phos } \\ 1 \mathrm{~h} & 5.01 & 220 & 603 & 302 & \text { nd } & \mathbf{- 1 7 . 1 6}-17.11 & -25.77 & -26.02 & -29.73 & -12.44 & \text { Phos, New } \\ 1 \mathrm{~d} & 4.96 & 152 & 584 & 209 & \text { nd } & -17.45-\mathbf{1 7 . 4 1} & -26.63 & -26.85 & -30.40 & -12.83 & \text { New }\end{array}$

\begin{tabular}{|c|c|c|c|c|c|c|c|c|c|c|c|}
\hline & $\mathrm{pH}^{*}$ & $\mathrm{Mg}$ & \multicolumn{2}{|c|}{--- $[\mathrm{mM}]$--- } & $\mathrm{Cl}$ & \multirow{2}{*}{\multicolumn{5}{|c|}{---ion activity-product--- }} & $\begin{array}{l}\text { solids*** } \\
\text { observed }\end{array}$ \\
\hline \multicolumn{11}{|c|}{ Newberyite } & \\
\hline New & 6.6 & 15.4 & 84 & 12.7 & 98 & -17.69 & -24.55 & -24.58 & -30.00 & -12.30 & New \\
\hline \multicolumn{12}{|c|}{ K-Struvite } \\
\hline $\mathrm{K}-\mathrm{Str} * v$ & 8.2 & 1.6 & 2023 & 830 & 725 & -18.47 & -25.19 & -25.60 & -29.04 & -10.27 & $K-s t r$ \\
\hline \multicolumn{12}{|c|}{ Variation $\mathrm{pH}$, samples with chloride and $\mathrm{KOH}$} \\
\hline $1 \_43$ & 5.0 & 74.3 & 121 & 60.3 & 185 & -17.93 & -27.70 & -27.76 & -31.97 & -13.99 & New \\
\hline $1 \_43$ & 5.0 & 74.3 & 124 & 60.8 & 187 & -17.94 & -27.74 & -27.80 & -31.98 & -14.00 & New \\
\hline \multicolumn{12}{|c|}{$1 \_86 \mathrm{~L}^{\mathrm{v}}$} \\
\hline $60 d$ & 6.6 & 15.4 & 84 & 12.7 & 96 & -17.70 & -24.64 & -24.67 & -30.07 & -12.34 & New \\
\hline $120 d$ & 5.4 & 28.3 & 67 & 31.7 & 94 & -18.02 & -27.33 & -27.35 & -31.94 & -13.90 & New \\
\hline $1 \_86 \mathrm{M}^{\mathrm{v}}$ & 7.1 & 13.6 & 107 & 21.7 & 101 & -17.40 & -23.13 & -23.16 & -28.85 & -11.43 & New, MO4 \\
\hline $\begin{array}{l}1-86 \mathrm{M}^{\mathrm{v}} \\
1-86 \mathrm{H}^{\mathrm{v}}\end{array}$ & 7.4 & 8.1 & 108 & 14.6 & 101 & -17.67 & -23.31 & -23.34 & -29.10 & -11.41 & New, MO4 \\
\hline $6 \overline{0} d$ & 8.3 & 3.4 & 112 & 12.5 & 99 & -18.00 & -22.41 & -22.44 & -28.78 & -10.76 & MO4, K-str \\
\hline $60 d$ & 8.3 & 3.4 & 110 & 12.4 & 100 & -17.99 & -22.41 & -22.44 & -28.79 & -10.77 & MO4, K-str \\
\hline $750 d$ & 8.6 & 0.92 & 125 & 15.0 & 108 & -18.52 & -23.54 & -23.57 & -29.51 & -10.98 & MO4, K-str, UP1 \\
\hline
\end{tabular}

$\mathrm{Mg} / \mathrm{PO}_{4}$ : Variation $\mathrm{Mg} / \mathrm{PO}_{4}$ at high $\mathrm{w} / \mathrm{s}$; $0564^{\mathrm{v}}$

\begin{tabular}{|c|c|c|c|c|c|c|c|c|c|c|c|}
\hline $60 \bar{d}$ & 7.3 & 8.7 & 87 & 61.1 & $<0.1$ & -17.29 & -22.83 & -22.85 & -28.47 & -11.17 & Cat, 15, New \\
\hline $60 d$ & 7.2 & 9.2 & 87 & 68.2 & $<0.1$ & -17.28 & -23.09 & -23.11 & -28.59 & -11.30 & Cat, 15, New \\
\hline $750 d$ & 8.3 & 1.84 & 101 & 56.2 & $<0.1$ & -17.95 & -22.87 & -22.89 & -28.72 & -10.76 & New, 15, Cat \\
\hline $06 \_62$ & 7.8 & 4.11 & 83 & 52.6 & $<0.1$ & -17.59 & -22.92 & -22.93 & -28.67 & -11.07 & Cat, 15 , New \\
\hline \multicolumn{12}{|l|}{$07_{-}^{-} 61^{\mathrm{v}}$} \\
\hline $60 d$ & 7.7 & 4.52 & 72 & 46.6 & $<0.1$ & -17.55 & -22.91 & -22.92 & -28.71 & -11.16 & Cat, 15, New \\
\hline $480 d$ & 8.2 & 2.03 & 77 & 44.0 & $<0.1$ & -17.89 & -22.84 & -22.85 & -28.80 & -10.91 & K-str, New, UP1 \\
\hline $08 \_59^{\mathrm{v}}$ & 8.4 & 2.7 & 60 & 35.5 & $<0.1$ & -17.75 & -22.12 & -22.14 & -28.51 & -10.75 & K-str, Cat, 15 \\
\hline $08 \_59^{\mathrm{v}}$ & 8.3 & 3.4 & 77 & 46.0 & $<0.1$ & -17.67 & -22.00 & -22.01 & -28.29 & -10.60 & K-str, Cat, 15 \\
\hline \multicolumn{12}{|l|}{ 1_ $\overline{5} 7 \mathrm{v}:$} \\
\hline $6 \overline{0} d$ & 8.5 & 3.0 & 53 & 35.6 & $<0.1$ & -17.70 & -21.65 & -21.67 & -28.30 & -10.59 & K-str \\
\hline $60 d$ & 8.5 & 3.0 & 61 & 35.7 & $<0.1$ & -17.71 & -21.71 & -21.72 & -28.28 & -10.56 & K-str \\
\hline $750 d$ & 10.9 & 0.090 & 13.0 & 4.2 & $<0.1$ & -19.93 & -22.92 & -22.92 & -30.91 & -10.97 & Cat, K-str \\
\hline \multicolumn{12}{|c|}{ 1.5_51 v: } \\
\hline $60 d$ & 11.8 & 0.035 & 13.4 & 2.8 & $<0.1$ & 21.12 & -24.41 & -24.42 & -32.39 & -11.26 & K-str, brucite \\
\hline $480 d$ & 12.0 & 0.029 & 20.6 & 4.3 & $<0.1$ & -21.40 & -24.88 & -24.88 & -32.57 & -11.17 & K-str, brucite \\
\hline
\end{tabular}

$\mathrm{Mg} / \mathrm{PO}_{4}$ : Variation $\mathrm{Mg} / \mathrm{PO}_{4}$ at low w/s $055^{v}$

$\begin{array}{lllll}75 d^{* v,} & 7.5 & 15.7 & 1149 & 781\end{array}$

$480 d^{*,} \quad 7.5 \quad 9.8 \quad 1210 \quad 738$ $0510^{\mathrm{v}}$,

$\begin{array}{llllr}75 d & 7.4 & 7.2 & 578 & 389 \\ 480 d & 7.5 & 4.5 & 621 & 367 \\ 08 \_5 & 7.6 & 8.8 & 623 & 447 \\ 08 \_10 & 7.9 & 4.6 & 348 & 215 \\ 1 \overline{5}^{\mathrm{v}} & & & & \\ 7 \overline{5}_{d} d & 8.6 & 1.9 & 292 & 173 \\ 480 d & 8.5 & 0.74 & 232 & 126 \\ 1 \_10^{\mathrm{v}} & & & & \\ 7 \overline{5} d & 8.2 & 2.7 & 200 & 122 \\ 480 d & 8.6 & 0.80 & 151 & 83\end{array}$

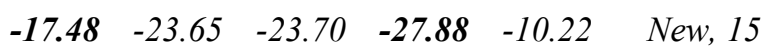
$\begin{array}{llllll}\mathbf{- 1 7 . 6 7} & -24.19 & -24.44 & \mathbf{- 2 8 . 1 2} & \mathbf{- 1 0 . 3 7} & \text { New, } K \text {-str, } 15\end{array}$

$\begin{array}{llllll}\mathbf{- 1 7 . 6 6} & -24.32 & -24.44 & \mathbf{- 2 8 . 5 4} & -10.79 & \text { New, } 15\end{array}$

$\begin{array}{llllll}\mathbf{- 1 7 . 8 5} & -24.67 & -24.79 & \mathbf{- 2 8 . 7 3} & -10.84 & \text { New, } 15\end{array}$

$\begin{array}{llllll}\mathbf{- 1 7 . 6 1} & -23.73 & -23.88 & \mathbf{- 2 8 . 2 0} & \mathbf{- 1 0 . 4 8} & \text { New, 15, K-str }\end{array}$

$\begin{array}{llllll}-17.74 & -23.34 & -23.40 & \mathbf{- 2 8 . 2 9} & \mathbf{- 1 0 . 5 0} & 15, \text { K-str }\end{array}$

$\begin{array}{llllll}-18.08 & -23.04 & \mathbf{- 2 3 . 1 0} & \mathbf{- 2 8 . 3 9} & \mathbf{- 1 0 . 2 7} & \text { Cat, K-str }\end{array}$

$\begin{array}{llllll}-18.45 & -24.15 & -24.19 & -29.21 & \mathbf{- 1 0 . 7 5} & \text { K-str }\end{array}$

$\begin{array}{llllll}-17.87 & -23.09 & \mathbf{- 2 3 . 1 3} & \mathbf{- 2 8 . 4 8} & \mathbf{- 1 0 . 5 8} & \text { 15, Cat, K-str }\end{array}$ $\begin{array}{llllll}-18.35 & -23.74 & -23.74 & -29.17 & \mathbf{- 1 0 . 8 1} & \text { K-str }\end{array}$ 
w/s: Variation water/solid prepared from magnesium sulfate

\begin{tabular}{|c|c|c|c|c|c|c|c|c|c|c|c|}
\hline & $\mathrm{pH}^{*}$ & $\mathrm{Mg}$ & \multicolumn{3}{|c|}{--- $[\mathrm{mM}]---$} & $\begin{array}{l}\text { New } \\
--- \text {-ior }\end{array}$ & $\begin{array}{l}\text { MO4 } \\
\text { activit }\end{array}$ & $\begin{array}{c}\text { Cat } \\
\text {-product }\end{array}$ & 15 & K-str & $\begin{array}{l}\text { solids** } \\
\text { observed }\end{array}$ \\
\hline $1 \_8 \mathrm{~S}$ & 7.7 & 19.2 & 778 & 24.0 & 510 & -17.97 & -23.37 & -23.50 & -28.70 & -10.63 & , Cat, 15 \\
\hline $1 \_10 \mathrm{~S}$ & 7.8 & 13.1 & 432 & 16.1 & 234 & -18.09 & -23.55 & -23.62 & -29.02 & -10.91 & \\
\hline $1-16 \mathrm{~S}$ & 7.5 & 20.4 & 392 & 23.6 & 266 & -17.74 & -23.23 & -23.30 & -28.67 & -10 & Cat, 15 \\
\hline $1-78 \mathrm{~S}$ & 7.5 & 12.1 & 99 & 14.2 & 58 & -17.70 & -23.16 & -23.18 & -29.11 & -11.39 & MO4 \\
\hline \multirow[t]{3}{*}{$1 \overline{3} \_10 \mathrm{~S}$} & 7.4 & 19.9 & 478 & 21.2 & 260 & $-17.87-$ & -23.72 & -23.81 & -28.93 & 11.04 & \\
\hline & & & & & & New & MO4 & Cat & 15 & K-str & \\
\hline & & & \multicolumn{9}{|c|}{--- solubility product --- } \\
\hline \multirow{2}{*}{\multicolumn{5}{|c|}{$\begin{array}{l}\text { Mean } \log \mathrm{K}_{\text {so at }} 20^{\circ} \mathrm{C}^{v^{*}} \\
\text { Standard deviation }\end{array}$}} & $-17.10^{v}$ & -17.73 & -22.99 & -22.97 & \multicolumn{3}{|c|}{$-28.85^{v^{* * *}}-10.70$} \\
\hline & & & & & \pm 0.16 & $\pm \mathbf{0 . 4 5}$ & \pm 1.16 & \pm 0.92 & \pm 0.42 & $\pm \mathbf{0 . 5 9}$ & \\
\hline \multicolumn{12}{|c|}{ 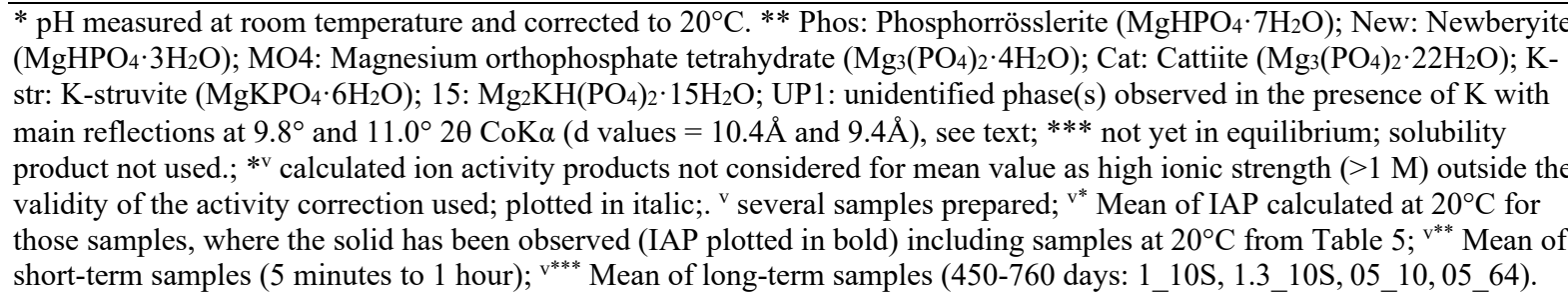 } \\
\hline
\end{tabular}

\subsection{Phosphorrösslerite $\left(\mathrm{MgHPO}_{4} \cdot 7 \mathrm{H}_{2} \mathrm{O}\right)$ and newberyite $\left(\mathrm{MgHPO}_{4} \cdot 3 \mathrm{H}_{2} \mathrm{O}\right)$}

At very short equilibration times of up to 1 hour, at low $\mathrm{pH}$ values and in the presence of high initial magnesium concentrations the occurrence of phosphorrösslerite $\left(\mathrm{MgHPO}_{4} \cdot 7 \mathrm{H}_{2} \mathrm{O}\right)$ is observed as summarised in Table 2 and shown in the Figure S.2 i(Supplementary Material). Phosphorrösslerite is destabilised after 1 hour and longer to newberyite $\left(\mathrm{MgHPO}_{4} \cdot 3 \mathrm{H}_{2} \mathrm{O}\right)$.

The total weight loss observed by TGA of $52.4 \mathrm{wt} . \%$ for phosphorrösslerite corresponds well to the theoretical weight loss of $51.2 \mathrm{wt} \% \%$ expected for the water loss of $\mathrm{MgHPO}_{4} \cdot 7 \mathrm{H}_{2} \mathrm{O}$. The TGA data in Figure S.2 (Supplementary Material) show also that phosphorrösslerite loses the first five water molecules between 40 and $120^{\circ} \mathrm{C}$ indicating that these water molecules are only loosely bound, while the last two, more strongly bound water molecules are lost between 120 and $200^{\circ} \mathrm{C}$. The sample equilibrated for 1 day, where only newberyite is present, shows a lower total weight loss of $30.6 \mathrm{wt} . \%$ between 120 and $250^{\circ} \mathrm{C} . \mathrm{XRD}$ data (Street and Whitaker, 1973) have shown that most of the water in the structure of phosphorrösslerite is loosely bound to $\mathrm{Mg}^{2+}$ without sharing of water between the different $\mathrm{Mg}\left(\mathrm{H}_{2} \mathrm{O}\right)_{6}$ units forming open water channels comparable to $\mathrm{K}$-struvite. This water is thus released at low temperatures during heating, similar as e.g. the water in the channels of the ettringite structure (Lothenbach et al., 2016). 
Phosphorrösslerite $\left(\mathrm{MgHPO}_{4} \cdot 7 \mathrm{H}_{2} \mathrm{O}\right)$ has a monoclinic structure (space group $\mathrm{C} 2 / \mathrm{c}$ (Street and Whitaker, 1973)) and contains more water than newberyite $\left(\mathrm{MgHPO}_{4} \cdot 3 \mathrm{H}_{2} \mathrm{O}\right)$, which has the same magnesium to phosphate ratio but an orthorhombic structure (space group Pbca) (Abbona et al., 1979; Bartl et al., 1983; Sutor, 1967). In agreement with the only transient observation of phosphorrösslerite (Figure S.2 in Supplementary Material), the formation of phosphorrösslerite is reported only during the first hours of hydration of MKP cements (Chau et al., 2012; Lahalle et al., 2018; Lahalle et al., 2016). Others authors observed only newberyite but no phosphorrösslerite (Le Rouzic, 2014; Le Rouzic et al., 2017a; Le Rouzic et al., 2017b; Xu et al., 2019). It has been reported that phosphorrösslerite can be transformed into newberyite during storage of samples before analysis (Lahalle et al., 2018), which would explain its infrequent observation in the literature indicating that phosphorrösslerite might have been present more often than reported.

At $\mathrm{pH}$ values below 7 and at equilibration times of 1 day and longer, the formation of newberyite $\left(\mathrm{MgHPO}_{4} \cdot 3 \mathrm{H}_{2} \mathrm{O}\right)$ is observed as summarised in Table 2. At $\mathrm{pH}$ values between 7 to 8.3 , newberyite is present together with magnesium orthophosphate tetrahydrate $\left(\mathrm{Mg}_{3}\left(\mathrm{PO}_{4}\right)_{2} \cdot 4 \mathrm{H}_{2} \mathrm{O}: \mathrm{MO} 4\right)$, while above pH 8.3 newberyite is absent. The formation of newberyite at low $\mathrm{pH}$ values and its destabilisation at higher $\mathrm{pH}$ values agrees with the observations by (Le Rouzic et al., 2017a) in hydrating MKP cements.

The XRD data of newberyite $\left(\mathrm{MgHPO}_{4} \cdot 3 \mathrm{H}_{2} \mathrm{O}\right)$ are reported in Figure S.3 (Supplementary Material) and agree well with the literature data (Abbona et al., 1979; Bartl et al., 1983; Sutor, 1967). Refinement of the structure indicated that the $\mathrm{H}_{2} \mathrm{O}$ groups are bound to the magnesium ion (Abbona et al., 1979; Bartl et al., 1983; Sutor, 1967). The obtained TGA shown in Supplementary Material indicate a total weight loss of $30.6 \mathrm{wt} . \%$ between 120 and $250^{\circ} \mathrm{C}$, consistent with the expected weight loss of $31.0 \mathrm{wt} . \%$ due to the loss of the 3 water molecules per formula unit. The main water loss at well above $100^{\circ} \mathrm{C}$ indicates a stronger water retention, consistent with the binding of the water groups to magnesium derived from XRD. A further gradual mass loss of $5.6 \mathrm{wt} . \%$ occurs above $250^{\circ} \mathrm{C}$, which is attributed to the weight loss of the $\mathrm{OH}$ group associated with the phosphate ion as newberyite decomposes to $\mathrm{MgHPO}_{4}$ and eventually to monoclinic $\beta$-magnesium pyrophosphate $\left(\mathrm{Mg}_{2} \mathrm{P}_{2} \mathrm{O}_{7}\right)$ upon further heating (Frost et al., 2011b). 
The FTIR and Raman spectra of newberyite in Table S.3 and Figure S.2 (Supplementary Material) show H-O-H stretching vibrations between 3200 and $3550 \mathrm{~cm}^{-1}$, i.e. at relatively high wavenumber consistent with the association of water with the magnesium. H-O-H bending vibrations are observed at 1640 and $1650 \mathrm{~cm}^{-1}$ as summarised in Table S.3 (Supplementary Material). $\mathrm{HPO}_{4}$ stretching vibrations are observed at $\approx 880 \mathrm{~cm}^{-1}$ and $\mathrm{PO}_{4}$ stretching vibrations between 980 and $1270 \mathrm{~cm}^{-1}$. Further $\mathrm{PO}_{4}$ bending vibrations are observed at 392, 500 and $603 \mathrm{~cm}^{-1}$ (FTIR) and 395, 497 and $519 \mathrm{~cm}^{-1}$ (Raman), in agreement with the observations of (Frost et al., 2011a; Frost et al., 2005) for newberyite. The SEM picture (Figure S.3A in Supplementary Material) shows that newberyite precipitates as angular particles.

To verify whether any dehydration of phosphorrösslerite to newberyite could have occurred during the drying of the later-age samples before analysis, a sample was analysed still wet directly after filtration. Both in wet and dry samples only newberyite was observed by XRD, indicating no systematic changes during the drying and (short) storage time before analysis. A newberyite sample was dried for 2 hours at $300^{\circ} \mathrm{C}$ to investigate the solids present after dehydration in TGA; an amorphous solid with a broad XRD signal at $32^{\circ} 2 \theta \mathrm{CoK} \alpha(\mathrm{d}$ value $=3.2 \AA)$ was observed, which could be $\mathrm{MgHPO}_{4}$ or a precursor of $\beta-\mathrm{Mg}_{2} \mathrm{P}_{2} \mathrm{O}_{7}$ as observed by (Frost et al., 2011b) after further heating.

The samples where newberyite or phopshorrösslerite were the dominant phases, had $\mathrm{pH}$ values between 5 to 8 and magnesium and phosphate concentrations between 10 to $300 \mathrm{mM}$ (Table 2). The magnesium and phosphate concentrations in equilibrium with newberyite decreased with increasing $\mathrm{pH}$ values. Based on the measured concentrations, ion activity products (IAP) for phosphorrösslerite and newberyite at $20{ }^{\circ} \mathrm{C}$ have been calculated (Table 2) using the thermodynamic software GEMS employing the data for aqueous species compiled in Table S.1 (Supplementary Material) as detailed in section 2.3 "Thermodynamic modelling".

A solubility product $\log \mathrm{K}_{\mathrm{SO}}$ of $-17.73 \pm 0.44$ for newberyite was derived from all measured data equilibrated for 30 days and longer from the measured data at $20^{\circ} \mathrm{C}$ (Table 2) at different $\mathrm{pH}$ values and in the presence of potassium, chloride or sulfate as also shown in Figure 1A. Newberyite was also observed at $40^{\circ} \mathrm{C}$ and $50^{\circ} \mathrm{C}$ (Table 3). At $40^{\circ} \mathrm{C}$ a $\log \mathrm{K}_{\text {so }}$ of -18.1 and at $50^{\circ} \mathrm{C}$ a $\log \mathrm{K}_{\text {so }}$ of -18.2 was calculated, indicating a slight stabilisation of newberyite at increasing temperatures. 

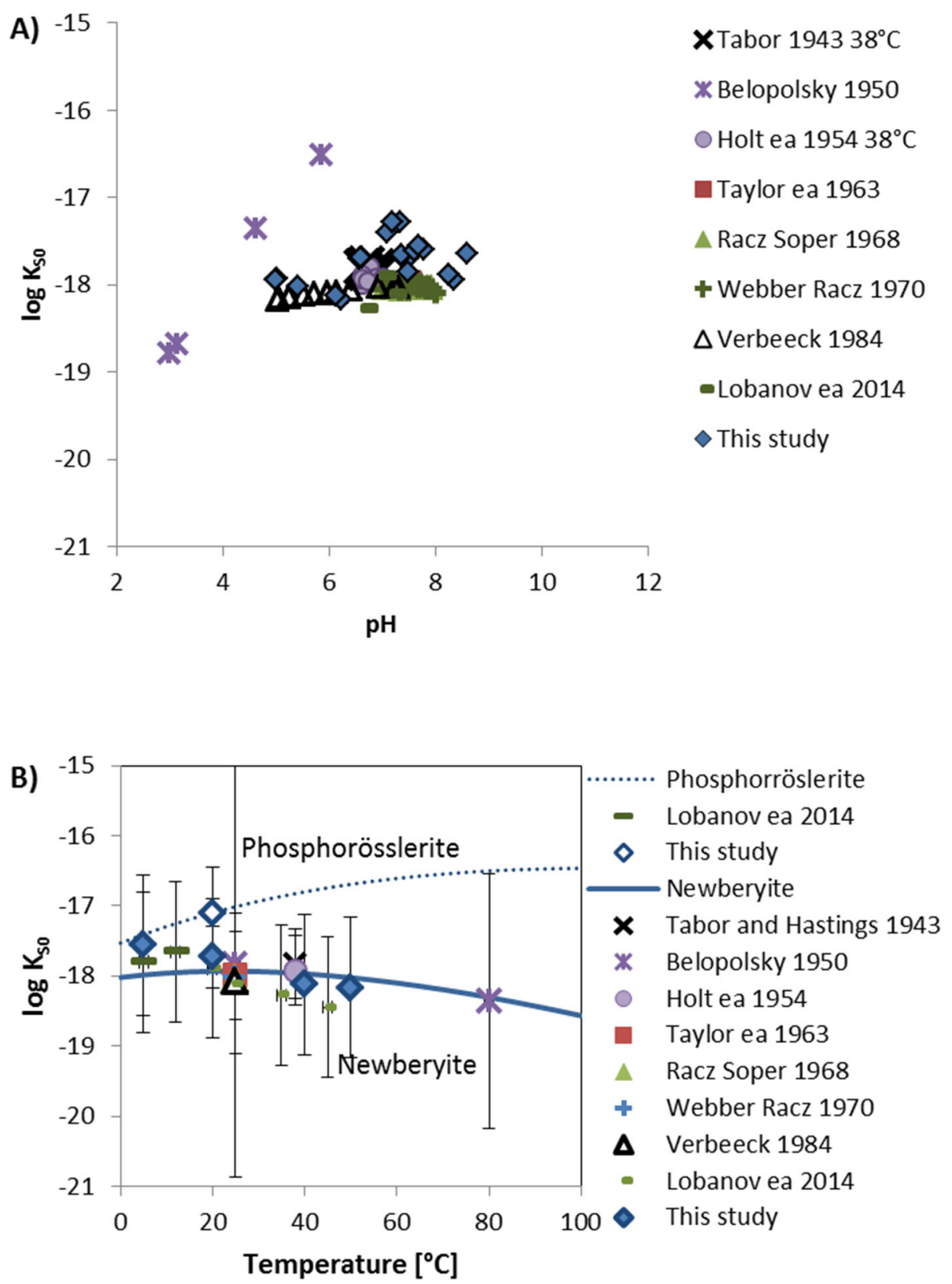

Figure 1: A) Solubility products for newberyite $\left(\mathrm{MgHPO}_{4} \cdot 3 \mathrm{H}_{2} \mathrm{O} \Leftrightarrow \mathrm{Mg}^{2+}+\mathrm{H}^{+}+\mathrm{PO}_{4}{ }^{3-}+3 \mathrm{H}_{2} \mathrm{O}\right)$ calculated from experimental data reported from 20 to $38^{\circ} \mathrm{C}$ in literature (Belopolsky et al., 1950; Holt et al., 1954; Lobanov, 2018; Lobanov et al., 2013; Racz and Soper, 1968; Tabor and Hastings, 1943; Taylor et al., 1963a; Taylor et al., 1963b; Verbeeck et al., 1984; Webber and Racz, 1970) and from this study as a function of $\mathrm{pH}, \mathrm{B})$ Solubility products for newberyite $\left(\mathrm{MgHPO}_{4} \cdot 3 \mathrm{H}_{2} \mathrm{O} \Leftrightarrow \mathrm{Mg}^{2+}+\mathrm{H}^{+}\right.$ $\left.+\mathrm{PO}_{4}{ }^{3-}+3 \mathrm{H}_{2} \mathrm{O}\right)$ and phosphorrösslerite $\left(\mathrm{MgHPO}_{4} \cdot 7 \mathrm{H}_{2} \mathrm{O} \Leftrightarrow \mathrm{Mg}^{2+}+\mathrm{H}^{+}+\mathrm{PO}_{4}{ }^{3-}+7 \mathrm{H}_{2} \mathrm{O}\right)$ as a function of temperature. The lines indicate the solubility calculated from the thermodynamic data compiled in Table 4.

Table 3: Measured concentrations, $\mathrm{pH}$ values and calculated ion activity products for magnesium phosphate solids investigated at different temperatures. Ion activity products for those solids, which were observed in the samples, are plotted in bold; only those IAP have been used to calculate solubility products. 


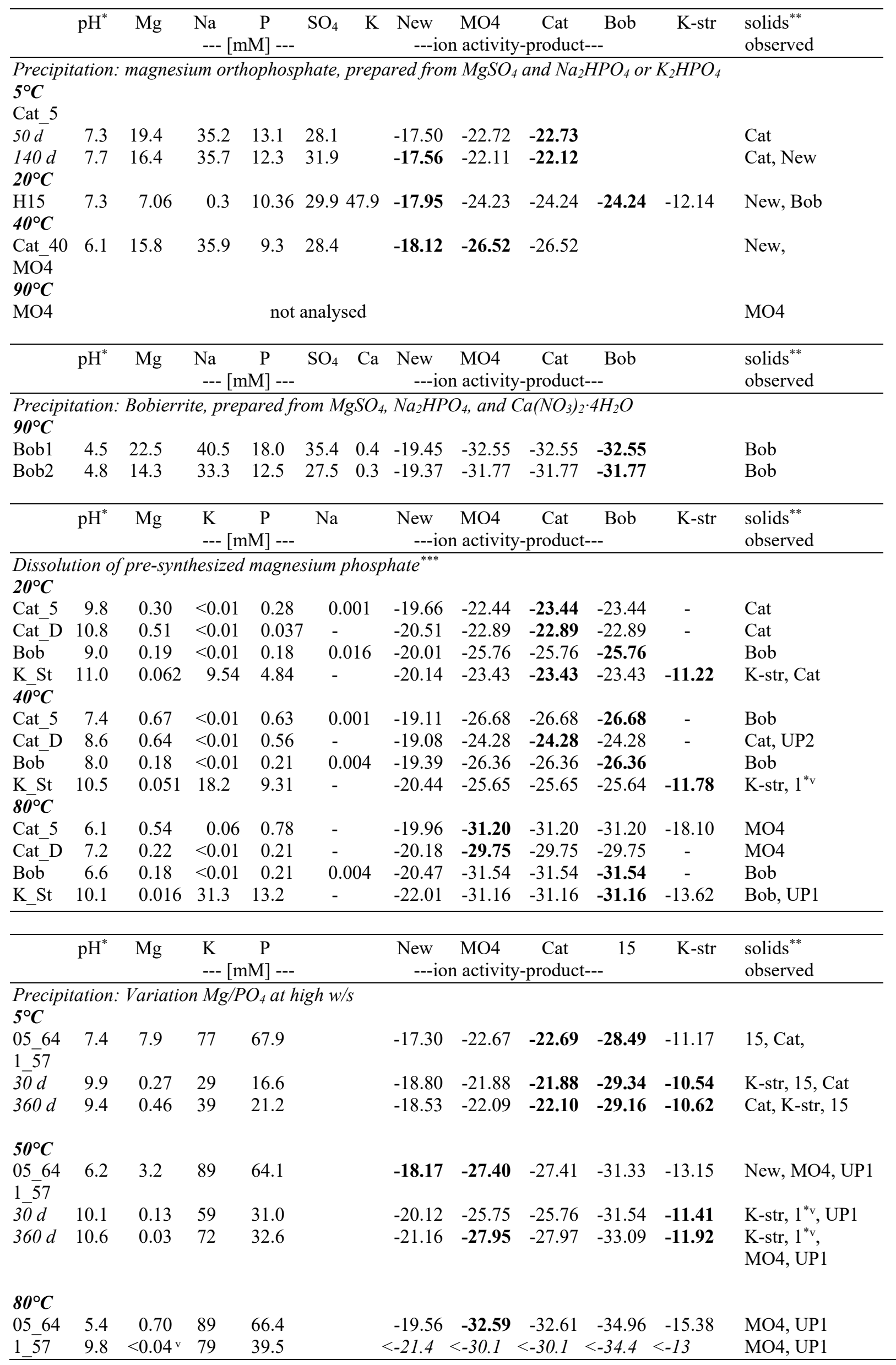


${ }^{*} \mathrm{pH}$ measured at room temperature and corrected to $5,20,40,50,80$ or $90^{\circ} \mathrm{C}$. ${ }^{* *}$ Phos: Phosphorrösslerite $\left(\mathrm{MgHPO}_{4} \cdot 7 \mathrm{H}_{2} \mathrm{O}\right)$; New: Newberyite $\left(\mathrm{MgHPO}_{4} \cdot 3 \mathrm{H}_{2} \mathrm{O}\right) ; 1: \mathrm{MgKPO}_{4} \cdot \mathrm{H}_{2} \mathrm{O} ; \mathrm{MO} 4$ : Magnesium orthophosphate tetrahydrate $\left(\mathrm{Mg}_{3}\left(\mathrm{PO}_{4}\right)_{2} \cdot 4 \mathrm{H}_{2} \mathrm{O}\right)$; Bob: Bobierrite $\left(\mathrm{Mg}_{3}\left(\mathrm{PO}_{4}\right)_{2} \cdot 8 \mathrm{H}_{2} \mathrm{O}\right)$; Cat: Cattiite $\left(\mathrm{Mg}_{3}\left(\mathrm{PO}_{4}\right)_{2} \cdot 22 \mathrm{H}_{2} \mathrm{O}\right)$; K-str: K-struvite $\left(\mathrm{MgKPO}_{4} \cdot 6 \mathrm{H}_{2} \mathrm{O}\right) ; 15$ :

$\mathrm{Mg}_{2} \mathrm{KH}\left(\mathrm{PO}_{4}\right)_{2} \cdot 15 \mathrm{H}_{2} \mathrm{O}$; UP1: unidentified phase(s) observed in the presence of $\mathrm{K}$ with main with main reflections at $9.8^{\circ}$ and $11.0^{\circ} 2 \theta \mathrm{CoK} \alpha(\mathrm{d}$ values $=10.4 \AA$ and $9.4 \AA)$, see text. UP2: unidentified phase(s) 2 with main reflection at $7.1^{\circ} 2 \theta \mathrm{CoK} \alpha(\mathrm{d}$ value $=14.4 \AA$ ) observed in the cattiite sample only. ${ }^{* * *} \mathrm{Na}$ and sulfate concentrations were in all cases below the detection limit of $0.004\left(\mathrm{Na}\right.$ ) and 0.001 (sulfate) $\mathrm{mM}^{{ }^{*}}{ }^{\mathrm{v}} \mathrm{MgKPO}_{4} \cdot \mathrm{H}_{2} \mathrm{O}$; its presence is also deduced form the decrease in $\mathrm{K}$ concentrations. ${ }^{\mathrm{v}}$ ion activity product not used as $\mathrm{Mg}$ concentrations below the detection limit; plotted in italics.

Solubility products for newberyite $\left(\mathrm{MgHPO}_{4} \cdot 3 \mathrm{H}_{2} \mathrm{O}\right)$ have also been reported in a number of papers at $25^{\circ} \mathrm{C}$ to $80^{\circ} \mathrm{C}$ as summarised in Table 4 . The reported solubility products at $25^{\circ} \mathrm{C}$ ranged from -17.8 to -18.2. Most solubility data for newberyite $\left(\mathrm{MgHPO}_{4} \cdot 3 \mathrm{H}_{2} \mathrm{O}\right)$ reported in literature are based on the measurements of (Racz and Soper, 1968; Taylor et al., 1963a; Taylor et al., 1963b). As in the older papers either the formation of $\mathrm{MgHPO}_{4}{ }^{\circ}$ and pyrophosphate complexes were neglected or a stronger complex formation constant of $\mathrm{MgHPO}_{4}{ }^{0}$ was used $\left(\log \mathrm{K}_{\mathrm{MgHPO} 40}=15.23\right.$ for $\mathrm{H}^{+}+\mathrm{PO}_{4}{ }^{3-}+\mathrm{Mg}^{2+} \Leftrightarrow$ $\mathrm{MgHPO}_{4}{ }^{0}$ ) than in the present work: $\log \mathrm{K}_{\mathrm{MgHPO} 40}=14.80$ ), all solubility data were recalculated as far as possible and compiled in the $2^{\text {nd }}$ half of Table 4 . The recalculation of the data of (Taylor et al., 1963a; Taylor et al., 1963b) and (Racz and Soper, 1968) using the data for aqueous species compiled in the Supplementary Material resulted in $\log \mathrm{K}_{\mathrm{SO}}=-17.99$ and -18.03 as shown in Figure 1. Also from the data measured by (Belopolsky et al., 1950; Holt et al., 1954; Lobanov, 2018; Lobanov et al., 2013; Tabor and Hastings, 1943; Verbeeck et al., 1984) comparable solubility products were obtained. These values calculated directly from the experimental data agree well with the $\mathrm{K}_{\mathrm{SO}}=-17.89$ fitted by (Babić-Ivančić et al., 2006) using the same complex formation constant of $\log \mathrm{K}_{\mathrm{MgHPO} 40}=14.80$ for $\mathrm{MgHPO}_{4}{ }^{0}$ as in the present work. From all these data a weighted mean value of $-17.93 \pm 0.23$ at $25^{\circ} \mathrm{C}$ was derived (see Table 4).

The solubility of newberyite was also calculated as a function of temperature based on the selected entropy and heat capacity values according to equation (2). As no measured heat capacity and entropy are available, they were estimated from the entropy and heat capacity data of K-struvite using $\Delta S_{r}=\Delta C_{p}$ $=0$ for the reaction $\mathrm{MgKPO}_{4} \cdot 6 \mathrm{H}_{2} \mathrm{O}$ (K-struvite) $-1 / 2 \mathrm{~K}_{2} \mathrm{O}-2^{1} / 2 \mathrm{H}_{2} \mathrm{O}_{\text {structural }} \Leftrightarrow \mathrm{MgHPO}_{4} \cdot 3 \mathrm{H}_{2} \mathrm{O}$ as detailed in Table 4. Despite the insecurity introduced by using estimated entropy and heat capacity data, the solubilities of newberyite and phosphorrösslerite calculated as a function of temperature agree well with the trends in the available measured data (Figure 1B) and indicate some stabilisation at higher 
temperature in the case of newberyite, while phosphorrösslerite is expected to become somewhat less unstable at lower temperature.

Table 4: Compilation of thermodynamic data for newberyite and phosphorrösslerite reported in the literature and determined in the present paper.

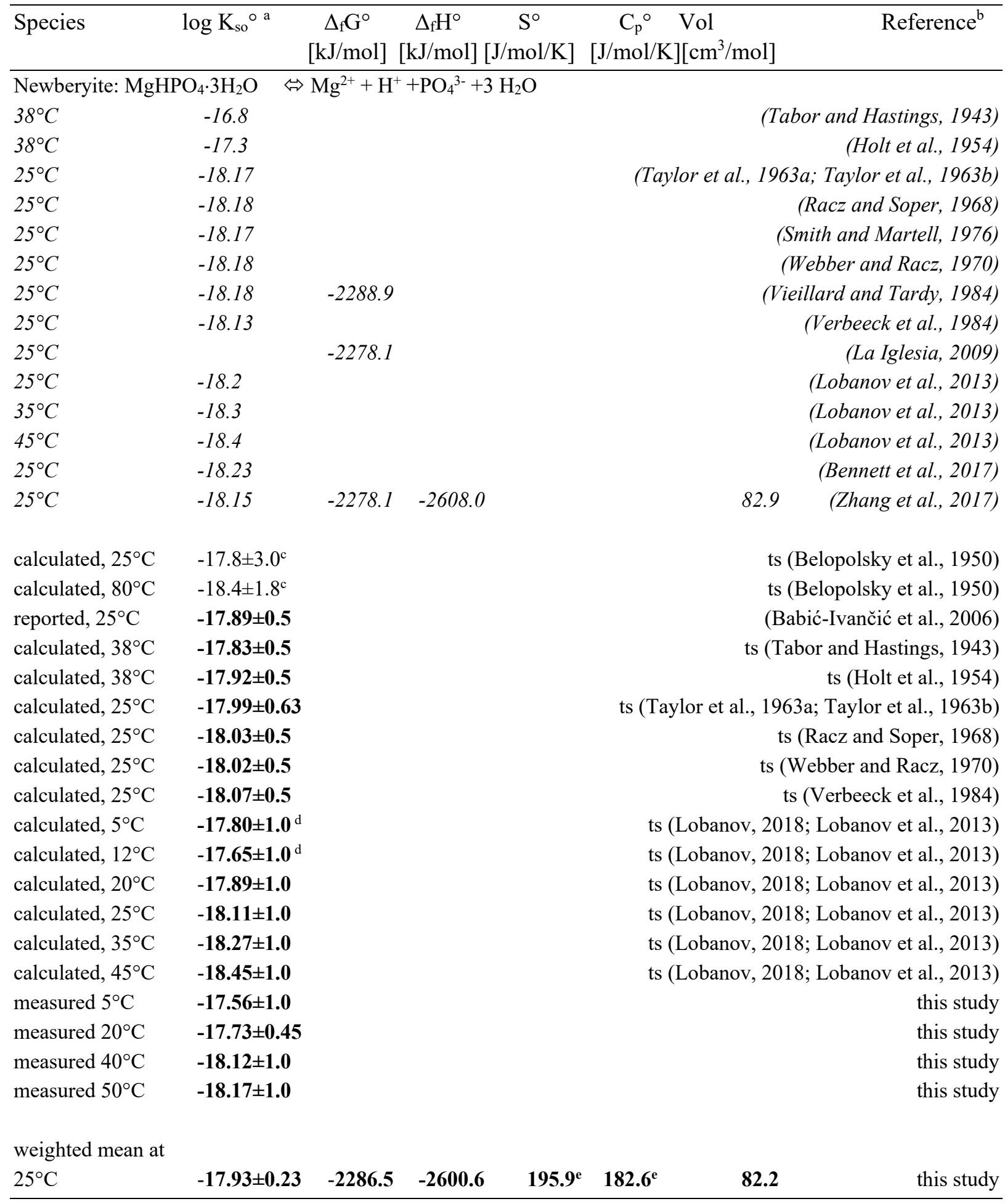

Phosphorrösslerite: $\mathrm{MgHPO}_{4} \cdot 7 \mathrm{H}_{2} \mathrm{O} \Leftrightarrow \mathrm{Mg}^{2+}+\mathrm{H}^{+}+\mathrm{PO}_{4}{ }^{3-}+7 \mathrm{H}_{2} \mathrm{O}$ 
calculated, $5^{\circ} \mathrm{C} \quad-17.80 \pm 1.0^{\mathrm{f}}$

calculated, $12^{\circ} \mathrm{C} \quad-17.65 \pm 1.0^{\mathrm{f}}$

measured $20^{\circ} \mathrm{C}$ ts (Lobanov, 2018; Lobanov et al., 2013)

ts (Lobanov, 2018; Lobanov et al., 2013)

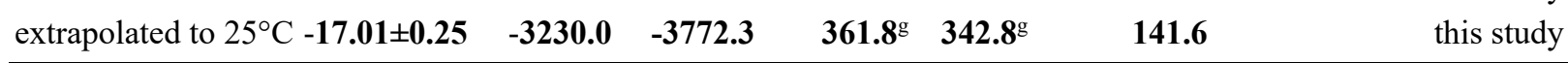

${ }^{a}$ solubility products refer to reactions formulated with $\mathrm{H}^{+}, \mathrm{Mg}^{2+}, \mathrm{PO}_{4}{ }^{3-}$ and $\mathrm{H}_{2} \mathrm{O} ;{ }^{\mathrm{b}}$ ts: calculated in this study using experimental data from the reference indicated; ${ }^{\mathrm{c}}$ no $\mathrm{pH}$ values were reported, resulting in a considerable variation in the calculated solubility products. ${ }^{\mathrm{d}}$ from partial destabilization of phosphorrösslerite. ${ }^{\mathrm{e}}$ obtained from $\Delta_{\mathrm{r}} \mathrm{S}^{\circ}=\Delta_{\mathrm{r}} \mathrm{C}_{\mathrm{p}}{ }^{\circ}=0$ for the isocoulombic reaction: $\mathrm{MgKPO}_{4} \cdot 6 \mathrm{H}_{2} \mathrm{O}$ (K-struvite) $-{ }^{1 / 2} \mathrm{~K}_{2} \mathrm{O}-2{ }^{1} /{ }_{2} \mathrm{H}_{2} \mathrm{O}_{\text {structural }} \Leftrightarrow$ $\mathrm{MgHPO}_{4} \cdot 3 \mathrm{H}_{2} \mathrm{O}$ (newberyite). Properties of $\mathrm{H}_{2} \mathrm{O}_{\text {structural }}\left(\mathrm{S}^{\circ}=40.2, \mathrm{~V}^{\circ}=13.7\right.$ and $\left.\mathrm{C}_{\mathrm{p}}{ }^{\circ}=40.0\right)$ from (Helgeson et al., 1978) were used. ${ }^{\mathrm{f}}$ measured after 4 days, partial destabilization to newberyite observed. ${ }^{\mathrm{g}}$ obtained from $\Delta_{\mathrm{r}} \mathrm{S}^{\circ}$ $=\Delta_{\mathrm{r}} \mathrm{C}_{\mathrm{p}}{ }^{\circ}=0$ for the isocoulombic reaction: $\mathrm{MgKPO}_{4} \cdot 6 \mathrm{H}_{2} \mathrm{O}$ (K-struvite) $-{ }_{-1} /{ }_{2} \mathrm{~K}_{2} \mathrm{O}+1{ }^{1} /{ }_{2} \mathrm{H}_{2} \mathrm{O}_{\text {structural }} \Leftrightarrow$ $\mathrm{MgHPO}_{4} \cdot 7 \mathrm{H}_{2} \mathrm{O}$ (phosphorrösslerite); to estimate the effect of water in the solid, $\mathrm{H}_{2} \mathrm{O}_{\text {structural }}\left(\mathrm{S}^{\circ}=40.2, \mathrm{~V}^{\circ}=13.7\right.$ and $\mathrm{C}_{\mathrm{p}}{ }^{\circ}=40.0$ ) from (Helgeson et al., 1978) was used.

For phosphorrösslerite a mean ion activity product of $-17.10 \pm 0.16$ at $20^{\circ} \mathrm{C}$ was derived from the concentrations measured after 5, 40 and 60 minutes as summarised in Table 2. After 1 day, where newberyite was observed, a clearly lower ion activity product of -17.45 was obtained. In none of the other experiments any phosphorrösslerite had been observed. The only other measured solubility products for phosphorrösslerite available have been determined at 5 and $12{ }^{\circ} \mathrm{C}$ using pre-synthesised phosphorrösslerite and an equilibration time of 4 days. These solubility products are with -18.0 and 17.8 ((Lobanov et al., 2013), see Table 4) somewhat more negative than the data measured here; this could be related to the observed partial destabilization of phosphorrösslerite in those experiments to newberyite and cattiite during the 4 days of those experiments. From the measured solubility products at $20^{\circ} \mathrm{C}$ and the calculated entropy and heat capacity data as given in Table 4, a solubility product of $17.1 \pm 0.3$ at $25^{\circ} \mathrm{C}$ was derived according to Eq. (2).

In Figure 1 the solubility product calculated for phosphorrösslerite is compared with solubility products derived for newberyite from literature data and own measurements, as discussed below. As phosphorrösslerite has been observed as intermediate phase only before newberyite formation, phosphorrösslerite can expected to be less stable than newberyite, i.e. phosphorrösslerite should have a less negative solubility product for the reaction $\mathrm{MgHPO}_{4} \cdot 7 \mathrm{H}_{2} \mathrm{O} \Leftrightarrow \mathrm{H}^{+}+\mathrm{PO}_{4}{ }^{3-}+\mathrm{Mg}^{2+}+7 \mathrm{H}_{2} \mathrm{O}^{0}$ than 
newberyite. The observed less negative solubility product of phosphorrösslerite confirms the instability of phosphorrösslerite towards newberyite and is consistent with the presence of phosphorrösslerite at early reaction times only (see Table 2 ).

The complete set of thermodynamic data selected for newberyite, phosphorösslerite and other solid phases relevant for MKP systems is summarised in Table 5.

Table 5: Standard thermodynamic properties of magnesium, phosphate and potassium containing solids and structural water at $25^{\circ} \mathrm{C}$ and 1 bar.

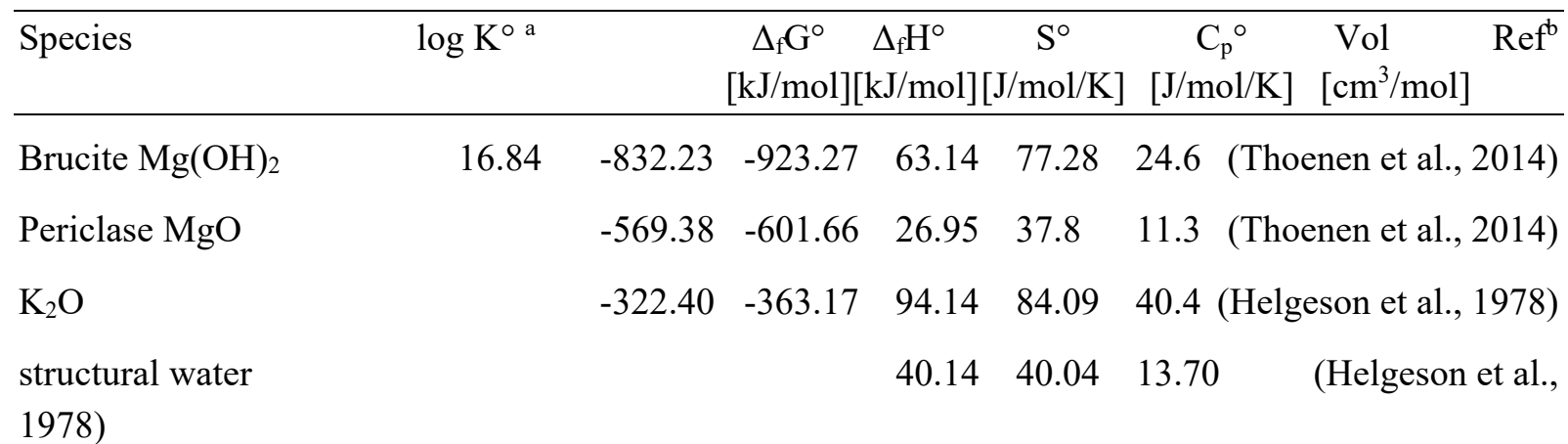

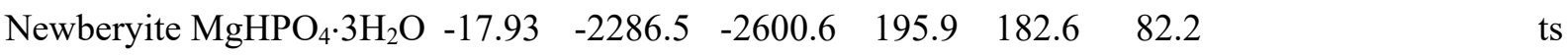

Phosphorrösslerite

$\begin{array}{llllllll}\mathrm{MgHPO}_{4} \cdot 7 \mathrm{H}_{2} \mathrm{O} & -17.01 & -3230.0 & -3772.8 & 361.8 & 342.8 & 141.6 & \text { ts }\end{array}$

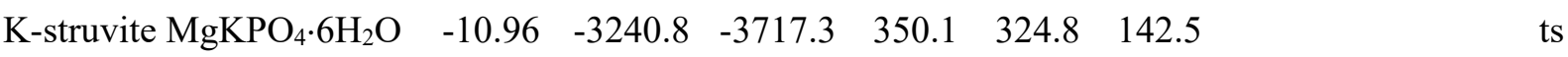

$\begin{array}{llllllll}\mathrm{MgKPO}_{4} \cdot \mathrm{H}_{2} \mathrm{O} & -10.95 & -2054.8 & -2245.8 & 141.3 & 124.6 & 66.1 & \text { ts }\end{array}$

$\begin{array}{lllllll}\mathrm{Mg}_{2} \mathrm{KH}\left(\mathrm{PO}_{4}\right)_{2} \cdot 15 \mathrm{H}_{2} \mathrm{O} & -28.67 & -6949.1 & -8086.7 & 781.6 & 747.6 & 303.2\end{array}$



$\begin{array}{lllllll}\mathrm{Mg}_{3}\left(\mathrm{PO}_{4}\right)_{2} \cdot 4 \mathrm{H}_{2} \mathrm{O} & -23.50 & -4482.1 & -4864.9 & 650.0 & 373.6 & 140.7\end{array}$

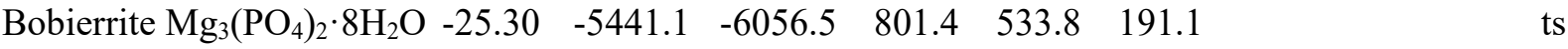

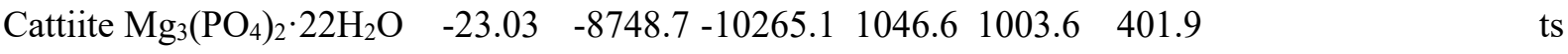

a solubility products refer to reactions formulated with $\mathrm{H}^{+}, \mathrm{K}^{+}, \mathrm{Mg}^{2+}, \mathrm{PO}_{4}{ }^{3-}$ and $\mathrm{H}_{2} \mathrm{O}$; ${ }^{\mathrm{b}}$ ts: calculated in this study; 


\subsection{K-struvite $\left(\mathrm{MgKPO}_{4} \cdot 6 \mathrm{H}_{2} \mathrm{O}\right)$ and $\mathrm{MgKPO}_{4} \cdot \mathrm{H}_{2} \mathrm{O}$}

At $\mathrm{pH}$ values above 8 or at $\mathrm{K}$ concentrations $>30 \mathrm{mM}$ the formation of $\mathrm{K}$-struvite $\left(\mathrm{MgKPO}_{4} \cdot 6 \mathrm{H}_{2} \mathrm{O}\right)$ is observed. $\mathrm{K}$-struvite was synthesised from $\mathrm{KH}_{2} \mathrm{PO}_{4}$ and $\mathrm{MgCl}_{2}$ as shown in Figure 2; the obtained pattern (Figure 2A) agrees with the pattern reported by (Graeser et al., 2008). K-struvite crystallizes in the orthorhombic crystal system, space group Pm21n (Graeser et al., 2008; Mathew and Schroeder, 1979); the water in the structure of $\mathrm{K}$-struvite is loosely bound to $\mathrm{Mg}^{2+}$ without sharing of water between the different $\mathrm{Mg}\left(\mathrm{H}_{2} \mathrm{O}\right)_{6}$ forming open water channels (Graeser et al., 2008), comparable to the structure of phosphorrösslerite. The presence of loosely bound water is confirmed by the mass loss of K-struvite at slightly above $100^{\circ} \mathrm{C}$ observed in the TGA data (Figure 2B); the measured weight loss of $41.1 \mathrm{wt} . \%$ agrees well with theoretical weight loss of 40.5 wt.\% upon complete dewatering: $\mathrm{MgKPO}_{4} \cdot 6 \mathrm{H}_{2} \mathrm{O}=>$ $\mathrm{MgKPO}_{4}+6 \mathrm{H}_{2} \mathrm{O}$. In addition, experiments on cements have shown that $\mathrm{K}$-struvite destabilises to $\mathrm{MgKPO}_{4} \cdot \mathrm{H}_{2} \mathrm{O}$ at $50^{\circ} \mathrm{C}$.

The FTIR spectra in Figure 2C shows broad H-O-H vibrations at around 1590, 2330 and $2870 \mathrm{~cm}^{-}$ 1; again the broad signals and low wavenumbers are consistent with poorly ordered water. Signals of $\mathrm{PO}_{4}$ stretching vibrations are observed at around $982 \mathrm{~cm}^{-1}$ (FTIR) and 946 and $1077 \mathrm{~cm}^{-1}$ (Raman) (Frost et al., 2005; Mácová and Viani, 2017; Stefov et al., 2004). Further $\mathrm{PO}_{4}$ bending vibration is observed at around $562 \mathrm{~cm}^{-1}$ (IR). The signals at around 431, $452 \mathrm{~cm}^{-1}$ (FTIR) and 431 and $470 \mathrm{~cm}^{-1}$ (Raman) could be either due to $\mathrm{PO}_{4}$ bending vibrations and/or Mg-O stretching (Frost et al., 2005; Mácová and Viani, 2017; Stefov et al., 2004). The Raman spectra bands at around 153, 231, and $302 \mathrm{~cm}^{-1}$ are due to $\mathrm{Mg}-\mathrm{O}$ stretching vibrations (Frost et al., 2005; Mácová and Viani, 2017; Stefov et al., 2004). The SEM picture in Figure 2D) shows that K-struvite crystallises as triangular platelets. The shape of precipitated Kstruvite can vary depending on the synthesis conditions; in low $\mathrm{Mg} / \mathrm{PO} 4$ cements rather needle-like or acicular K-struvite is observed (Chau et al., 2011; Le Rouzic et al., 2017b). 






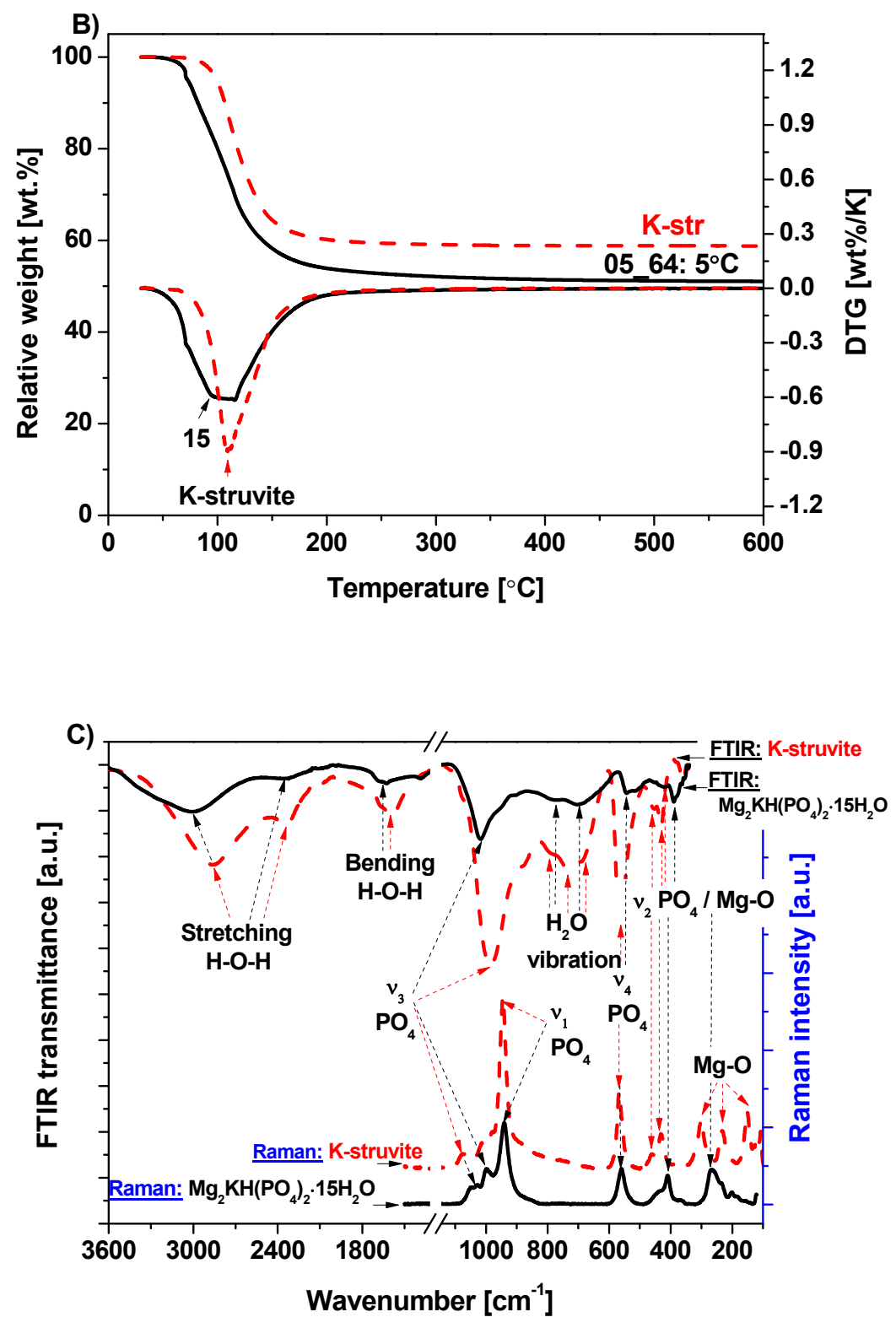

\section{D) K-struvite}

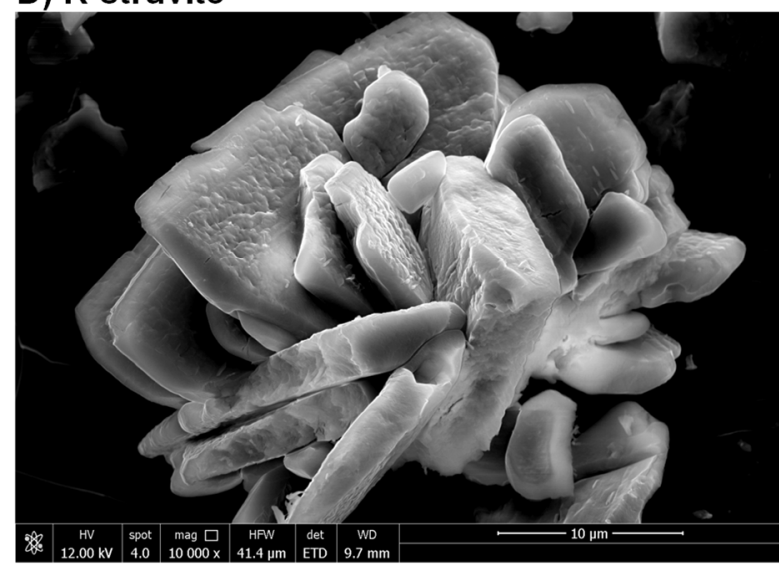

E) $\mathrm{Mg}_{2} \mathrm{KH}\left(\mathrm{PO}_{4}\right)_{2} \cdot 15 \mathrm{H}_{2} \mathrm{O}$

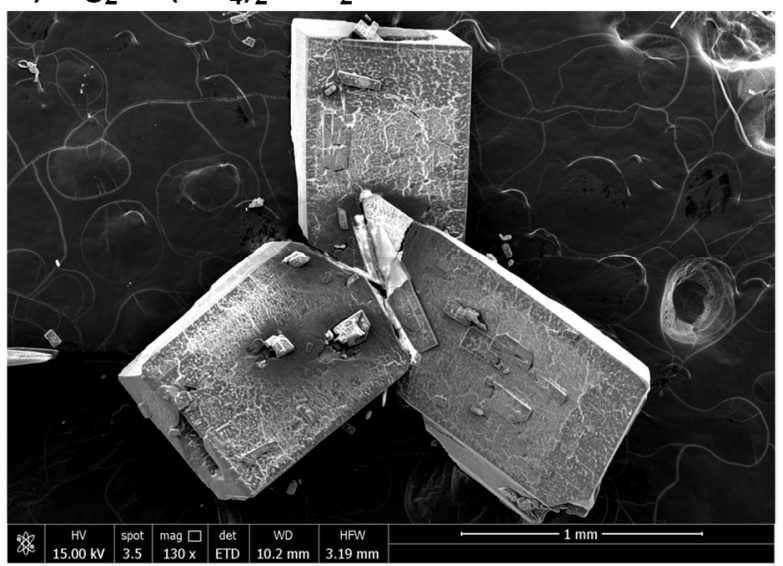

Figure 2: A) XRD patterns of $\mathrm{K}$-struvite and $\mathrm{Mg}_{2} \mathrm{KH}\left(\mathrm{PO}_{4}\right)_{2} \cdot 15 \mathrm{H}_{2} \mathrm{O}$ (sample 05_64: $5{ }^{\circ} \mathrm{C}$ ). $\mathrm{C}$ : $\mathrm{Mg}_{3}\left(\mathrm{PO}_{4}\right)_{2} \cdot 22 \mathrm{H}_{2} \mathrm{O} ; \quad \mathrm{S}: \quad \mathrm{MgKPO}_{4} \cdot 6 \mathrm{H}_{2} \mathrm{O} ;$ 15: $\mathrm{Mg}_{2} \mathrm{KH}\left(\mathrm{PO}_{4}\right)_{2} \cdot 15 \mathrm{H}_{2} \mathrm{O} ;$ B) TGA/DTG curves; C) 
FTIR/Raman curves; D) SEM image of K-struvite synthesized at $20{ }^{\circ} \mathrm{C}$; E) SEM image of $\mathrm{Mg}_{2} \mathrm{KH}\left(\mathrm{PO}_{4}\right)_{2} \cdot 15 \mathrm{H}_{2} \mathrm{O}$ synthesized at $5{ }^{\circ} \mathrm{C}$ for $30 \mathrm{~d}$. Details on the synthesis procedures of $\mathrm{K}$-str and 05_64: $5^{\circ} \mathrm{C}$ are given in Table 1-1 and 1-3.

Some thermodynamic data for K-struvite have been reported in the literature as compiled in Table 6. (Bennett et al., 2017; Frank, 2013; Taylor et al., 1963a; Yang et al., 2019) have determined solubility products in the range of $\mathrm{K}_{\mathrm{SO}}=-10.6$ to -11.0 at $25^{\circ} \mathrm{C}$ from measurements between $\mathrm{pH} 8$ and 12. (Luff and Reed, 1980) determined heat capacity, entropy and enthalpy of K-struvite (Table 6) and derived based on these data a much lower solubility of -11.7 .

Our experiments compiled in Table 2 and Table 3 resulted in a $\log \mathrm{K}_{\mathrm{SO}}$ of $-10.77 \pm 0.55$ at $20^{\circ} \mathrm{C}$; the consideration of only long-term data (360 days and longer) and the under-saturation experiment (Table 3) gave a slightly lower, but statistically not significantly different, value of $-10.98 \pm 0.42$. Together with the solubility products recalculated from data of (Bennett et al., 2017; Frank, 2013; Taylor et al., 1963a) and the data compiled in Table 3 , a $\log \mathrm{K}_{\mathrm{so}}$ of $-11.0 \pm 0.3$ at $25^{\circ} \mathrm{C}$ was derived (see Table 6 ). The enthalpy of $-3717 \mathrm{~kJ} / \mathrm{mol}$, calculated from the Gibbs free energy obtained from the solubility product and the entropy determined by (Luff and Reed, 1980) is comparable to the reported enthalpy of $-3722 \pm 21 \mathrm{~kJ} / \mathrm{mol}$ (Luff and Reed, 1980) and the $-3724 \mathrm{~kJ} / \mathrm{mol}$ and $-3729 \mathrm{~kJ} / \mathrm{mol}$ estimated by (Vieillard and Tardy, 1984) and (La Iglesia, 2009).

The entropy and heat capacity data measured by (Luff and Reed, 1980) result in only small changes in the solubility of K-struvite with temperature, which agrees well with the measured trends shown in Figure 3. The limited solubility variation with temperature is similar to newberyite and to struvite $\left(\mathrm{MgNH}_{4} \mathrm{PO}_{4} \cdot 6 \mathrm{H}_{2} \mathrm{O}\right)$, which also shows only a weak dependence of its solubility on temperature (Aage et al., 1997).

At 50 and $80^{\circ} \mathrm{C}$ less or no K-struvite was observed by XRD and TGA than at $20^{\circ} \mathrm{C}$, although the potassium concentrations were reduced, consistent with the (partial) formation of $\mathrm{MgKPO}_{4} \cdot \mathrm{H}_{2} \mathrm{O}$. Thus, K-struvite can be expected to be more stable than $\mathrm{Mg}_{2} \mathrm{KH}\left(\mathrm{PO}_{4}\right)_{2} \cdot 15 \mathrm{H}_{2} \mathrm{O}$ below $25^{\circ} \mathrm{C}$; at $50^{\circ} \mathrm{C}$ and above rather the formation of $\mathrm{MgKPO}_{4} \cdot \mathrm{H}_{2} \mathrm{O}$ and $\mathrm{Mg}_{3}\left(\mathrm{PO}_{4}\right)_{2} \cdot 4 \mathrm{H}_{2} \mathrm{O}$ can be expected (Table 3). 

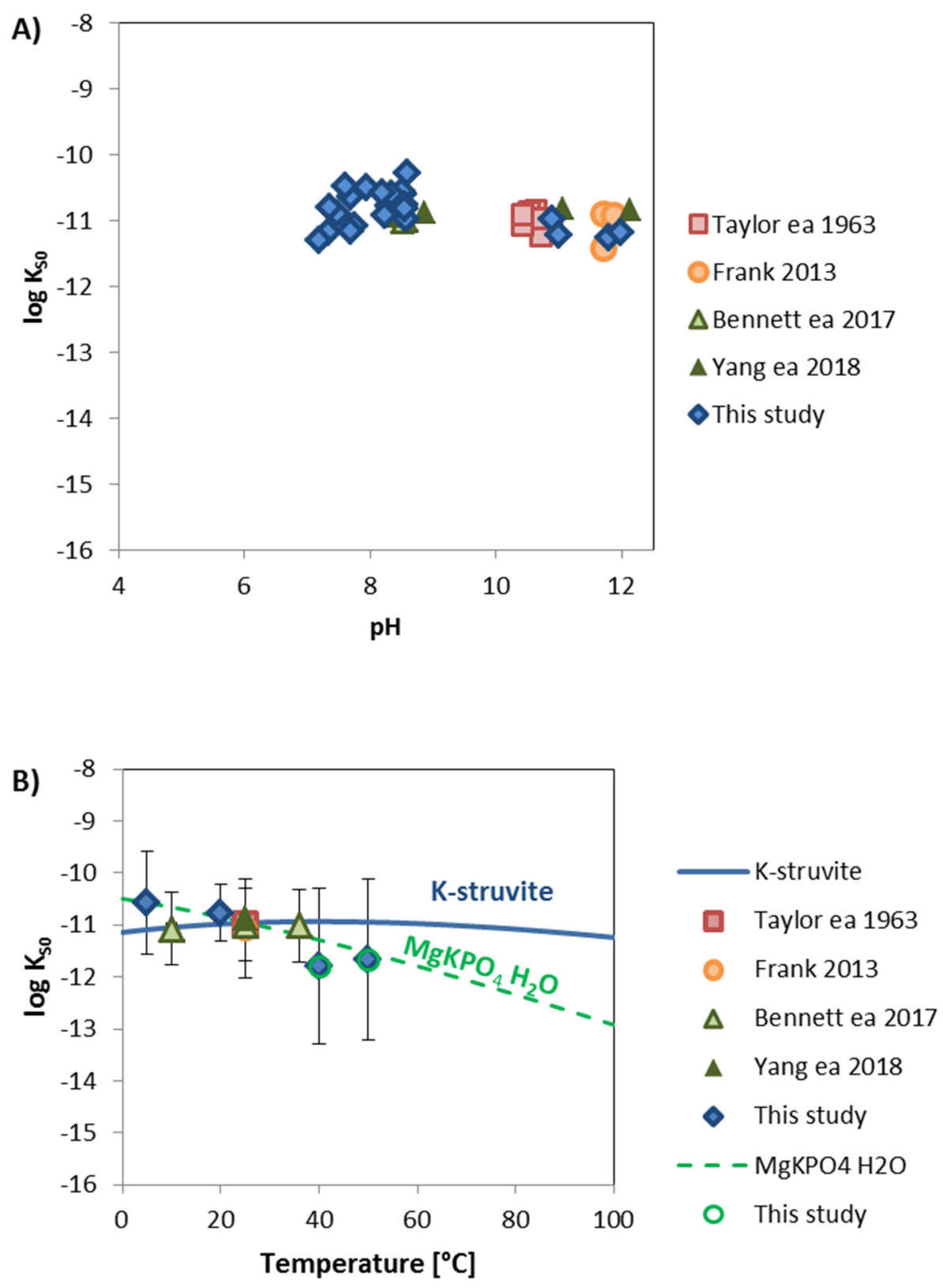

Figure 3: A) Calculated solubility products for K-struvite $\left(\mathrm{MgKPO}_{4} \cdot 6 \mathrm{H}_{2} \mathrm{O} \Leftrightarrow \mathrm{Mg}^{2+}+\mathrm{K}^{+}+\mathrm{PO}_{4}{ }^{3-}+\right.$ $6 \mathrm{H}_{2} \mathrm{O}$ ) from experimental data reported in literature at $20^{\circ} \mathrm{C}$ (this study) and $25^{\circ} \mathrm{C}$ (Bennett et al., 2017; Frank, 2013; Taylor et al., 1963a; Yang et al., 2019) as a function of $\mathrm{pH}$ and B) calculated solubility products of $\mathrm{K}$-struvite and $\mathrm{MgKPO}_{4}$ as a function of temperature. The solid line indicates the K-struvite solubility calculated from the thermodynamic data compiled in Table 5 and Table 6; the dashed line gives the calculated solubility product of $\mathrm{MgKPO}_{4} \cdot \mathrm{H}_{2} \mathrm{O}$, i.e. dehydrated K-struvite.

Table 6: Compilation of thermodynamic data for K-struvite $\left(\mathrm{MgKPO}_{4} \cdot 6 \mathrm{H}_{2} \mathrm{O}\right), \mathrm{MgKPO}_{4} \cdot \mathrm{H}_{2} \mathrm{O}$ and

$\mathrm{Mg}_{2} \mathrm{KH}\left(\mathrm{PO}_{4}\right)_{2} \cdot 15 \mathrm{H}_{2} \mathrm{O}$ reported in the literature and determined in the present paper.

\begin{tabular}{lcccccc}
\hline Species & $\log \mathrm{K}^{\circ \mathrm{a}}$ & $\begin{array}{c}\Delta_{\mathrm{f}} \mathrm{G}^{\circ} \\
{[\mathrm{kJ} / \mathrm{mol}]}\end{array}$ & $\begin{array}{c}\Delta_{\mathrm{f}} \mathrm{H}^{\circ} \\
{[\mathrm{kJ} / \mathrm{mol}]}\end{array}$ & $\begin{array}{c}\mathrm{S}^{\circ} \\
{[\mathrm{J} / \mathrm{mol} / \mathrm{K}]}\end{array}$ & $\begin{array}{c}\mathrm{C}_{\mathrm{p}}{ }^{\circ} \\
{[\mathrm{J} / \mathrm{mol} / \mathrm{K}]}\end{array}$ & $\begin{array}{c}\text { Vol } \\
{\left[\mathrm{cm}^{3} / \mathrm{mol}\right]}\end{array}$ \\
$\mathrm{MgKPO}_{4} \cdot 6 \mathrm{H}_{2} \mathrm{O} \Leftrightarrow \mathrm{Rg}^{2+}+\mathrm{K}^{+}+\mathrm{PO}_{4}{ }^{3-}+6 \mathrm{H}_{2} \mathrm{O}$ &
\end{tabular}




\begin{tabular}{|c|c|c|c|c|c|c|c|}
\hline $25^{\circ} \mathrm{C}$ & -10.62 & & & & & & (Taylor et al., 1963a) \\
\hline $25^{\circ} \mathrm{C}$ & -11.68 & & $-3722 \pm 21$ & 350.1 & 324.8 & & (Luff and Reed, 1980) \\
\hline $25^{\circ} \mathrm{C}$ & -10.84 & & & & & & (Frank, 2013) \\
\hline $25^{\circ} \mathrm{C}$ & -10.63 & -3241 & -3724.3 & 330 & & & (Vieillard and Tardy, 1984) \\
\hline $25^{\circ} \mathrm{C}$ & & -3257.2 & -3729.3 & & & & (La Iglesia, 2009) \\
\hline $25^{\circ} \mathrm{C}$ & & -3241 & -3724.3 & & & & (Chau et al., 2012) \\
\hline $25^{\circ} \mathrm{C}$ & -10.62 & -3241 & -3724.3 & & & 156.5 & (Zhang et al., 2017) \\
\hline $10^{\circ} \mathrm{C}$ & -11.07 & & & & & & (Bennett et al., 2017) \\
\hline $25^{\circ} \mathrm{C}$ & -11.00 & & & & & & (Bennett et al., 2017) \\
\hline $36^{\circ} \mathrm{C}$ & -10.90 & & & & & & (Bennett et al., 2017) \\
\hline $25^{\circ} \mathrm{C}$ & -10.87 & & & & & & (Yang et al., 2019) \\
\hline calculated, $25^{\circ} \mathrm{C}$ & $-10.98 \pm 0.5$ & & & & & & ts (Taylor et al., 1963a) \\
\hline calculated, $25^{\circ} \mathrm{C}$ & $-11.08 \pm 0.95$ & & & & & & ts (Frank, 2013) \\
\hline calculated $10^{\circ} \mathrm{C}$ & $-11.07 \pm 0.7$ & & & & & & ts (Bennett et al., 2017) \\
\hline calculated $25^{\circ} \mathrm{C}$ & $-11.00 \pm 0.7$ & & & & & & ts (Bennett et al., 2017) \\
\hline calculated $36^{\circ} \mathrm{C}$ & $-11.01 \pm 0.7$ & & & & & & ts (Bennett et al., 2017) \\
\hline measured $5^{\circ} \mathrm{C}$ & $-10.58 \pm 1.0$ & & & & & & this study \\
\hline measured $20^{\circ} \mathrm{C}$ & $-10.77 \pm 0.55$ & & & & & & this study \\
\hline measured $40^{\circ} \mathrm{C}$ & $-11.78 \pm 2.0$ & & & & & & this study \\
\hline measured $50^{\circ} \mathrm{C}$ & $-11.67 \pm 1.5$ & & & & & & this study \\
\hline \multicolumn{8}{|l|}{ weighted mean at } \\
\hline $25^{\circ} \mathrm{C}$ & $-10.96 \pm 0.31$ & -3240.8 & -3717.3 & 350.1 & 324.8 & 142.5 & this study \\
\hline \multicolumn{8}{|c|}{$\mathrm{MgKPO}_{4} \cdot \mathrm{H}_{2} \mathrm{O} \Leftrightarrow \mathrm{Mg}^{2+}+\mathrm{K}^{+}+\mathrm{PO}_{4}{ }^{3-}+6 \mathrm{H}_{2} \mathrm{O}$} \\
\hline measured $40^{\circ} \mathrm{C}$ & $-11.78 \pm 1.5$ & & & & & & this study \\
\hline measured $50^{\circ} \mathrm{C}$ & $-11.66 \pm 1.5$ & & & & & & this study \\
\hline derived mean at & & & & & & & \\
\hline $25^{\circ} \mathrm{C}$ & $-10.95 \pm 1.50$ & -2054.8 & -2245.8 & $141.3^{\mathrm{c}}$ & $124.6^{c}$ & 66.1 & this study \\
\hline \multicolumn{8}{|c|}{$\mathrm{Mg}_{2} \mathrm{KH}\left(\mathrm{PO}_{4}\right)_{2} \cdot 15 \mathrm{H}_{2} \mathrm{O} \Leftrightarrow 2 \mathrm{Mg}^{2+}+\mathrm{K}^{+}+\mathrm{H}^{+}+2 \mathrm{PO}_{4}^{3-}+15 \mathrm{H}_{2} \mathrm{O}$} \\
\hline $25^{\circ} \mathrm{C}$ & & -6969.9 & -8142.3 & & & & (Chau et al., 2012) \\
\hline $25^{\circ} \mathrm{C}$ & -29.54 & -6969.9 & -8142.3 & & & 293.0 & (Zhang et al., 2017) \\
\hline $\begin{array}{l}\text { measured } 5^{\circ} \mathrm{C} \\
\text { measured } 20^{\circ} \mathrm{C}\end{array}$ & $-28.99 \pm 1.43$ & & & & & & this study \\
\hline $\begin{array}{l}450-760 \text { days } \\
\text { weighted mean at }\end{array}$ & $-28.85 \pm 0.42$ & & & & & & this study \\
\hline $25^{\circ} \mathrm{C}$ & $-28.67 \pm 0.60$ & -6949.1 & -8086.7 & $781.6^{\mathrm{d}}$ & $747.6^{\mathrm{d}}$ & 303.2 & this study \\
\hline \multicolumn{8}{|c|}{$\begin{array}{l}\text { a solubility products refer to reactions formulated with } \mathrm{H}^{+}, \mathrm{Mg}^{2+}, \mathrm{PO}_{4}{ }^{3-} \text { and } \mathrm{H}_{2} \mathrm{O} ;{ }^{b} \text { ts: calculated in this study } \\
\text { using experimental data from the reference indicated;. }{ }^{\mathrm{c}} \Delta_{\mathrm{r}} \mathrm{S}^{\circ}=\Delta_{\mathrm{r}} \mathrm{C}_{\mathrm{p}}{ }^{\circ}=0 \text { for the isocoulombic reaction: } \\
\mathrm{MgKPO}_{4}{ }^{0} \cdot 6 \mathrm{H}_{2} \mathrm{O} \Leftrightarrow \mathrm{MgKPO}_{4} \cdot \mathrm{H}_{2} \mathrm{O}+5 \mathrm{H}_{2} \mathrm{O}_{\text {structural }} \text { using } \mathrm{S}^{\circ}=40.2 \text { and } \mathrm{C}_{\mathrm{p}}{ }^{\circ}=40.0 \text { for structural water from } \\
\text { (Helgeson et al., 1978). }{ }^{\mathrm{d}} \Delta_{\mathrm{r}} \mathrm{S}^{\circ}=\Delta_{\mathrm{r}} \mathrm{C}_{\mathrm{p}}{ }^{\circ}=0 \text { for the isocoulombic reaction: } \mathrm{MgHPO}_{4}{ }^{0} \cdot 7 \mathrm{H}_{2} \mathrm{O}+\mathrm{MgKPO}_{4}{ }^{0} \cdot 6 \mathrm{H}_{2} \mathrm{O} \\
+2 \mathrm{H}_{2} \mathrm{O}_{\text {structural }} \Leftrightarrow \mathrm{Mg}_{2} \mathrm{KH}\left(\mathrm{PO}_{4}\right)_{2} \cdot 15 \mathrm{H}_{2} \mathrm{O} \text {. }\end{array}$} \\
\hline
\end{tabular}




\section{$3.3 \mathrm{Mg}_{2} \mathrm{KH}\left(\mathrm{PO}_{4}\right)_{2} \cdot 15 \mathrm{H}_{2} \mathrm{O}$}

At $\mathrm{pH}$ values between 7.0 and 8.5 the formation of another water-rich magnesium phosphate, $\mathrm{Mg}_{2} \mathrm{KH}\left(\mathrm{PO}_{4}\right)_{2} \cdot 15 \mathrm{H}_{2} \mathrm{O}$, was observed. The formation of $\mathrm{Mg}_{2} \mathrm{KH}\left(\mathrm{PO}_{4}\right)_{2} \cdot 15 \mathrm{H}_{2} \mathrm{O}$ occurred together with cattiite at lower $\mathrm{pH}$ values (see Table 2); at $\mathrm{pH}$ values above 8 or at $\mathrm{K}$ concentrations $>30 \mathrm{mM}$ together with K-struvite $\left(\mathrm{MgKPO}_{4} \cdot 6 \mathrm{H}_{2} \mathrm{O}\right)$. At $20^{\circ} \mathrm{C}, \mathrm{Mg}_{2} \mathrm{KH}\left(\mathrm{PO}_{4}\right)_{2} \cdot 15 \mathrm{H}_{2} \mathrm{O}$ was only present at higher $\mathrm{PO}_{4}$ concentrations $(\geq 24 \mathrm{mM})$; at lower concentrations magnesium orthophosphate tetrahydrate (MO4) formed instead. $\mathrm{Mg}_{2} \mathrm{KH}\left(\mathrm{PO}_{4}\right)_{2} \cdot 15 \mathrm{H}_{2} \mathrm{O}$ precipitated as the main phase at $5^{\circ} \mathrm{C}$, while it was present as minor phase only at $20^{\circ} \mathrm{C}$ and completely absent at higher temperatures, indicating a strong destabilisation of $\mathrm{Mg}_{2} \mathrm{KH}\left(\mathrm{PO}_{4}\right)_{2} \cdot 15 \mathrm{H}_{2} \mathrm{O}$ with increasing temperature.

The TGA data in Figure S.3B (Supplementary Material) of the sample obtained at $5^{\circ} \mathrm{C}$ indicated a main water loss of the loosely bound water between 50 to $200^{\circ} \mathrm{C}$ with a total weight loss 45.9 wt.\%, i.e. slightly lower than the theoretical mass loss of $49.2 \mathrm{wt.} \%$; the observed $45.9 \mathrm{wt} . \%$, would correspond rather to 14 instead of 15 water per formula unit. XRD studies have indicated that the water and potassium in the structure of $\mathrm{Mg}_{2} \mathrm{KH}\left(\mathrm{PO}_{4}\right)_{2} \cdot 15 \mathrm{H}_{2} \mathrm{O}$ are present in channels (Takagi et al., 1982) consistent with the water loss at low temperatures. The water in the structure of $\mathrm{Mg}_{2} \mathrm{KH}\left(\mathrm{PO}_{4}\right)_{2} \cdot 15 \mathrm{H}_{2} \mathrm{O}$ is loosely bound to $\mathrm{Mg}^{2+}$ without sharing of water between the different $\mathrm{Mg}\left(\mathrm{H}_{2} \mathrm{O}\right)_{6}$ as in the case of $\mathrm{K}$ struvite and phosphorrösslerite. Also its chemical composition lies between phosporrösslerite and Kstruvite, although the crystal system of $\mathrm{Mg}_{2} \mathrm{KH}\left(\mathrm{PO}_{4}\right)_{2} \cdot 15 \mathrm{H}_{2} \mathrm{O}$ (anorthic, space group P-1, density 1.81 $\mathrm{cm}^{3} / \mathrm{g}$ (Takagi et al., 1982)) is different to those of K-struvite (orthorhombic, space group Pm21n (Graeser et al., 2008)) or phosphorrösslerite (monoclinic, space group C2/c (Street and Whitaker, 1973)).

The FTIR spectra in Figure S.3C (Supplementary Material) show H-O-H vibrations at around 1637, 2356 and $3009 \mathrm{~cm}^{-1}$ (IR) due to the presence of poorly ordered water similar to K-struvite and consistent with the high water loss at low temperature observed by TGA. As in the case of $\mathrm{K}$-struvite, $\mathrm{PO}_{4}$ stretching vibrations are observed at around $1017 \mathrm{~cm}^{-1}$ (FTIR) and 941, 998 and $1030 \mathrm{~cm}^{-1}$ (Raman) (Koleva et al., 2017; Koleva et al., 2015; Pecovska-Gjorgjevich et al., 2018; Stefov et al., 2017). Further $\mathrm{PO}_{4}$ bending vibration is observed at $544 \mathrm{~cm}^{-1}$ (FTIR) and $560 \mathrm{~cm}^{-1}$ (Raman) (Koleva et al., 2017; Koleva et al., 2015; Pecovska-Gjorgjevich et al., 2018; Stefov et al., 2017). The signals at around 389 and 420 $\mathrm{cm}^{-1}$ (FTIR) and 268 and $410 \mathrm{~cm}^{-1}$ (Raman) could be due to bending vibrations of $\mathrm{PO}_{4}$ or $\mathrm{Mg}-\mathrm{O}$ 
stretching vibrations (Koleva et al., 2017; Koleva et al., 2015; Pecovska-Gjorgjevich et al., 2018; Stefov et al., 2017). The SEM picture in Figure 2shows that $\mathrm{Mg}_{2} \mathrm{KH}\left(\mathrm{PO}_{4}\right)_{2} \cdot 15 \mathrm{H}_{2} \mathrm{O}$ crystallises as rectangular platelets.

The formation of $\mathrm{Mg}_{2} \mathrm{KH}\left(\mathrm{PO}_{4}\right)_{2} \cdot 15 \mathrm{H}_{2} \mathrm{O}$ has been observed in the experiments shown here as well as at early reaction times in MKP cements hydrating at ambient temperature (Chau et al., 2012; Lahalle et al., 2018; Lahalle et al., 2016; Xu et al., 2018a; Xu et al., 2019), however, its solubility had not yet been determined experimentally. Recently its thermodynamic properties have been estimated by (Chau et al., 2012) assuming that the $\Delta_{\mathrm{r}} \mathrm{G}=\Delta_{\mathrm{r}} \mathrm{H}=0$ from the oxides, from which a $\log \mathrm{K}$ of -29.5 had been suggested by (Zhang et al., 2017) as indicated in Table 6. The experimental data collected in Table 2 and Figure 4 indicate a somewhat less negative solubility product in the range -28.2 to -29.0 for $\mathrm{Mg}_{2} \mathrm{KH}\left(\mathrm{PO}_{4}\right)_{2} \cdot 15 \mathrm{H}_{2} \mathrm{O}$ at $20^{\circ} \mathrm{C}$; the four long-term measurements (480 and 760 days) result in a mean solubility of -28.85 ; those data were selected. The solubility of $\mathrm{Mg}_{2} \mathrm{KH}\left(\mathrm{PO}_{4}\right)_{2} \cdot 15 \mathrm{H}_{2} \mathrm{O}$ increases with temperature (Figure 4) such that $\mathrm{Mg}_{2} \mathrm{KH}\left(\mathrm{PO}_{4}\right)_{2} \cdot 15 \mathrm{H}_{2} \mathrm{O}$ is stabilised at lower temperature and not expected to be observed above ambient temperatures, in agreement with the absence in any of the experiments above $20^{\circ} \mathrm{C}$ and its presence as intermediate phase only during the hydration of MKP cements (Chau et al., 2012; Lahalle et al., 2018; Lahalle et al., 2016; Xu et al., 2018a; Xu et al., 2019). As an intermediate phase between newberyite and $\mathrm{K}$-struvite, in the long-term $\mathrm{Mg}_{2} \mathrm{KH}\left(\mathrm{PO}_{4}\right)_{2} \cdot 15 \mathrm{H}_{2} \mathrm{O}$ is only stable if its solubility product is comparable or more negative than the cumulative solubility product of newberyite and K-struvite (log $\left.\mathrm{K}_{\mathrm{MgHPO} 43 \mathrm{H} 2 \mathrm{O}}+\log _{\mathrm{MgKPO} 4 \cdot 6 \mathrm{H} 2 \mathrm{O}}=\log \mathrm{K}_{\mathrm{Mg} 2 \mathrm{KH}(\mathrm{PO} 4) 2 \cdot 15 \mathrm{H} 2 \mathrm{O}} \sim-28.8\right)$. The comparable solubility suggests that $\mathrm{Mg}_{2} \mathrm{KH}\left(\mathrm{PO}_{4}\right)_{2} \cdot 15 \mathrm{H}_{2} \mathrm{O}$ can be stable at $20^{\circ} \mathrm{C}$ in the long-term and is stabilised at temperatures below $20^{\circ} \mathrm{C}$, which agrees with the long-term experiments in Table 2 (samples 05_64, 05_10, 05_5, 1_10S and 1.3_10S) at $\mathrm{pH}$ values 7.2 to 8.5 (Figure 4A). Thus $\mathrm{Mg}_{2} \mathrm{KH}\left(\mathrm{PO}_{4}\right)_{2} \cdot 15 \mathrm{H}_{2} \mathrm{O}$ is formed at intermediate $\mathrm{pH}$ values and preferentially at lower temperatures; at higher temperatures it will destabilise to newberyite or K-struvite. Its stability is expected to be limited to intermediate $\mathrm{pH}$ values also at lower temperatures. In agreement with the solubility trends plotted in Figure 4, $\mathrm{Mg}_{2} \mathrm{KH}\left(\mathrm{PO}_{4}\right)_{2} \cdot 15 \mathrm{H}_{2} \mathrm{O}$ is observed at 5 and $20^{\circ} \mathrm{C}$ (Table 2, Table 3) even after long equilibration times, but never at 50 or $80{ }^{\circ} \mathrm{C}$, where instead $\mathrm{K}$-struvite or magnesium orthophosphate tetrahydrate (MO4) have been formed. 

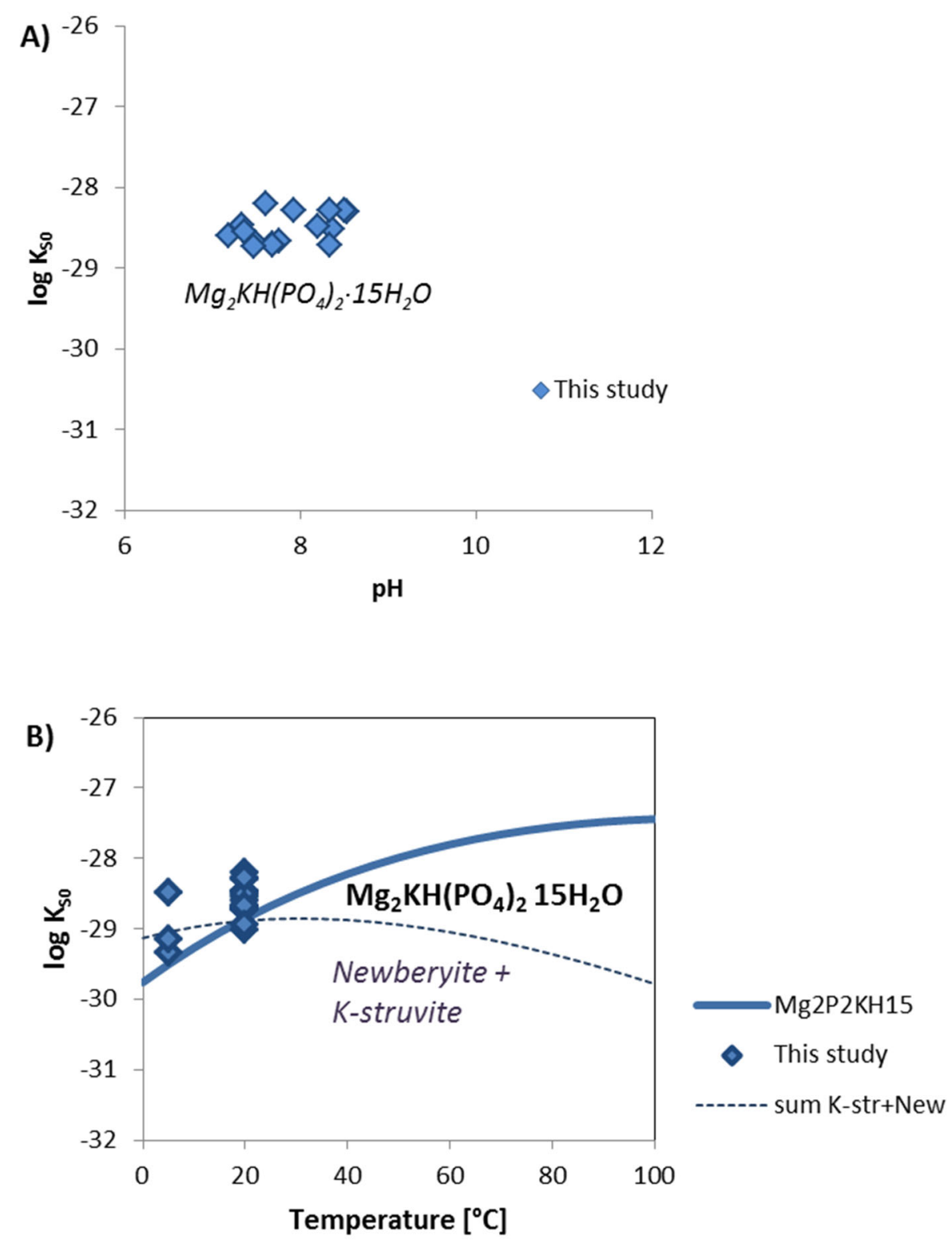

Figure 4: Solubility products for $\mathrm{Mg}_{2} \mathrm{KH}\left(\mathrm{PO}_{4}\right)_{2} \cdot 15 \mathrm{H}_{2} \mathrm{O} \Leftrightarrow 2 \mathrm{Mg}^{2+}+\mathrm{K}^{+}+\mathrm{H}^{+}+2 \mathrm{PO}_{4}{ }^{3-}+15 \mathrm{H}_{2} \mathrm{O}$ calculated from experimental data measured in this study. A) at $20^{\circ} \mathrm{C}$ as a function of $\mathrm{pH}$ and $\mathrm{B}$ ) the data at 5 and $20^{\circ} \mathrm{C}$ as a function of temperature. The solid line indicates the solubility of calculated $\mathrm{Mg}_{2} \mathrm{KH}\left(\mathrm{PO}_{4}\right)_{2} \cdot 15 \mathrm{H}_{2} \mathrm{O}$ from the thermodynamic data compiled in Table 5, the dotted line shows for comparison the sum of the solubility of newberyite and K-struvite.

\subsection{Magnesium orthophosphates}

At intermediate $\mathrm{pH}$ values the formation of magnesium orthophosphate tetrahydrate (MO4: $\left.\mathrm{Mg}_{3}\left(\mathrm{PO}_{4}\right)_{2} \cdot 4 \mathrm{H}_{2} \mathrm{O}\right)$ or cattiite $\left(\mathrm{MO} 22: \mathrm{Mg}_{3}\left(\mathrm{PO}_{4}\right)_{2} \cdot 22 \mathrm{H}_{2} \mathrm{O}\right)$ was observed in the present study, while bobierrite (MO8: $\left.\mathrm{Mg}_{3}\left(\mathrm{PO}_{4}\right)_{2} \cdot 8 \mathrm{H}_{2} \mathrm{O}\right)$ was formed only in the presence of some calcium or potassium as detailed in Table 3. Although these minerals have - with exception of the water content - the same 
chemical composition, their crystal systems are different. Cattiite has an anortic systems (space group P-1) (Catti et al., 1981; Schroeder et al., 1978), bobierrite crystallizes in the monoclinic crystal system (space group C2/c) (Takagi et al., 1986), while magnesium orthophosphates tetrahydrate has an orthorhombic structure (Kongshaug et al., 2001). The spectra of the synthesized phase-pure samples are summarised in Figure S.4 (Supplementary Material). The measured total weight losses during TGA are with 21.9 wt.\% for MO4, 35.7 wt.\% for MO8 and 59.2 wt.\% for MO22 comparable to the theoretical weight losses of $21.5,35.4$ and 60.1 wt.\%, respectively.

Cattiite (MO22) shows the main weight loss at around $100^{\circ} \mathrm{C}$ indicating loosely bound water similar to phosphorrösslerite, $\mathrm{Mg}_{2} \mathrm{KH}\left(\mathrm{PO}_{4}\right)_{2} \cdot 15 \mathrm{H}_{2} \mathrm{O}$ and $\mathrm{K}$-struvite, while $\mathrm{MO} 8$ loses its water at $200^{\circ} \mathrm{C}$. $\mathrm{MO} 4$ loses its 4 water in two steps, at $200{ }^{\circ} \mathrm{C}$ and at $330^{\circ} \mathrm{C}$. The water in the structure of cattiite (M22) is loosely bound to $\mathrm{Mg}^{2+}$ without sharing of water between the different $\mathrm{Mg}\left(\mathrm{H}_{2} \mathrm{O}\right)_{6}$, comparable to $\mathrm{K}$ struvite, $\mathrm{Mg}_{2} \mathrm{KH}\left(\mathrm{PO}_{4}\right)_{2} \cdot 15 \mathrm{H}_{2} \mathrm{O}$ and phosphorrösslerite. Also the FTIR signal of MO22 in Figure S.4C (Supplementary Material) shows, similar to K-struvite, a very broad signal due to H-O-H stretching vibrations between 2200 and $3000 \mathrm{~cm}^{-1}$. The main signals of $\mathrm{PO}_{4}$ stretching vibrations is observed at around 980, 1057, $1160 \mathrm{~cm}^{-1}$ (FTIR) and 936, $1005 \mathrm{~cm}^{-1}$ (Raman) similar to the main signals of Kstruvite (Frost et al., 2005; Mácová and Viani, 2017; Stefov et al., 2004) and $\mathrm{Mg}_{2} \mathrm{KH}\left(\mathrm{PO}_{4}\right)_{2} \cdot 15 \mathrm{H}_{2} \mathrm{O}$ (Koleva et al., 2017; Koleva et al., 2015; Pecovska-Gjorgjevich et al., 2018; Stefov et al., 2017). Further $\mathrm{PO}_{4}$ bending vibrations are observed at around $553 \mathrm{~cm}^{-1}$ (FTIR) and $558 \mathrm{~cm}^{-1}$ (Raman). The signals at $390 \mathrm{~cm}^{-1}$ (FTIR) and $436 \mathrm{~cm}^{-1}$ (Raman) could be due to $\mathrm{PO}_{4}$ bending vibration and/or Mg-O stretching vibration. The Raman signals at 131, 218 and $285 \mathrm{~cm}^{-1}$ could be assigned to Mg-O stretching vibrations.

The FTIR and Raman spectra in Figure S.4C (Supplementary Material) show little intensity for the vibrations associated with water for MO4, more for bobierrite and cattiite. The narrower band at 3051 $\mathrm{cm}^{-1}$ for MO8 shows a higher degree of ordering of the bound water than for cattiite, consistent with the different temperatures due to water loss observed by TGA. Both MO8 and MO4 show several $\mathrm{PO}_{4}$ stretching vibrations at around 950 to $1080 \mathrm{~cm}^{-1}$ for MO8, and between 940 and $1165 \mathrm{~cm}^{-1}$ for MO4 as detailed in Table S.3 (Supplementary Material). The FTIR showed much broader bands for cattiite indicating less ordering than for bobierrite or MO4, while no such differences in the band broadness was observed for the Raman bands. 


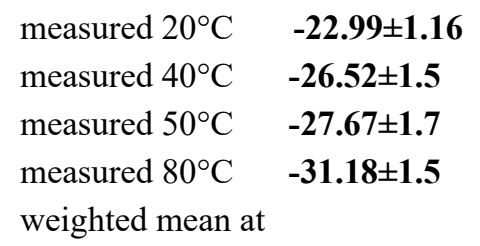

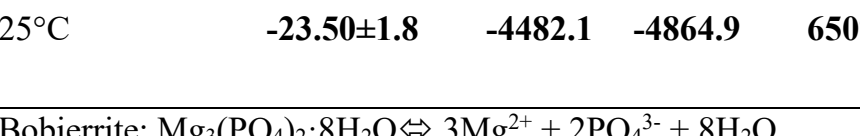

$\begin{array}{llll}25^{\circ} \mathrm{C} & -25.20 & & \\ 25^{\circ} \mathrm{C} & -25.22 & -5450.5 & \\ 25^{\circ} \mathrm{C} & & -5435.3 & \\ 35^{\circ} \mathrm{C} & -26.0 & & \\ 45^{\circ} \mathrm{C} & -27.0 & & \\ 55^{\circ} \mathrm{C} & -27.6 & & \\ 25^{\circ} \mathrm{C} & -25.47 & & \\ 25^{\circ} \mathrm{C} & -25.19 & -5458.1 & -6199.4\end{array}$

(Taylor et al., 1963a; Taylor et al., 1963b) (Vieillard and Tardy, 1984) (La Iglesia, 2009) (Lobanov et al., 2013) (Lobanov et al., 2013) (Lobanov et al., 2013) (Bennett et al., 2017) $223.1 \quad$ (Zhang et al., 2017)

calculated, $25^{\circ} \mathrm{C} \quad-\mathbf{- 2 4 . 5 0} \pm \mathbf{0 . 8 5}$

calculated, $20^{\circ} \mathrm{C} \quad-\mathbf{2 4 . 4 4} \pm \mathbf{1 . 5}$

calculated, $35^{\circ} \mathrm{C} \quad-\mathbf{2 6 . 0 7} \pm \mathbf{1 . 5}$

calculated, $45^{\circ} \mathrm{C} \quad-\mathbf{2 7 . 0 0} \pm \mathbf{1 . 5}$

calculated, $55^{\circ} \mathrm{C} \quad-\mathbf{2 7 . 1 6} \pm \mathbf{1 . 5}$

calculated, $65^{\circ} \mathrm{C} \quad \mathbf{- 3 0 . 8 2} \pm \mathbf{1 . 5}$

calculated, $75^{\circ} \mathrm{C} \quad \mathbf{- 2 9 . 9 1} \pm \mathbf{1 . 5}$

calculated, $36^{\circ} \mathrm{C} \quad \mathbf{- 2 4 . 8 1} \pm \mathbf{0 . 7 9}$

measured $20^{\circ} \mathrm{C} \quad \mathbf{- 2 5 . 0 0} \pm \mathbf{4 . 6 1}$

measured $40^{\circ} \mathrm{C} \quad-\mathbf{2 6 . 2 3} \pm \mathbf{1 . 6 9}$

measured $80^{\circ} \mathrm{C} \quad-\mathbf{3 1 . 3 5} \pm \mathbf{1 . 1 5}$

measured $90^{\circ} \mathrm{C} \quad-\mathbf{3 2 . 1 6} \pm \mathbf{2 . 3 9}$

weighted mean at ts (Taylor et al., 1963a; Taylor et al., 1963b) ts (Lobanov, 2018; Lobanov et al., 2013) ts (Lobanov, 2018; Lobanov et al., 2013) ts (Lobanov, 2018; Lobanov et al., 2013) ts (Lobanov, 2018; Lobanov et al., 2013) ts (Lobanov, 2018; Lobanov et al., 2013) ts (Lobanov, 2018; Lobanov et al., 2013) ts (Bennett et al., 2017) this study this study this study this study this study

\begin{tabular}{|c|c|c|c|}
\hline \multicolumn{4}{|c|}{ Cattiite: $\mathrm{Mg}_{3}\left(\mathrm{PO}_{4}\right)_{2} \cdot 22 \mathrm{H}_{2} \mathrm{O} \Leftrightarrow 3 \mathrm{Mg}^{2+}+2 \mathrm{PO}_{4}^{3-}+22 \mathrm{H}_{2} \mathrm{O}$} \\
\hline $25^{\circ} \mathrm{C}$ & -23.12 & & \\
\hline $25^{\circ} \mathrm{C}$ & -23.70 & & \\
\hline $25^{\circ} \mathrm{C}$ & -23.12 & -8751.8 & \\
\hline $25^{\circ} \mathrm{C}$ & & -8782.6 & \\
\hline $5^{\circ} \mathrm{C}$ & -24.0 & & \\
\hline $12^{\circ} \mathrm{C}$ & -23.7 & & \\
\hline $20^{\circ} \mathrm{C}$ & -23.4 & & \\
\hline $25^{\circ} \mathrm{C}$ & -23.22 & & \\
\hline $25^{\circ} \mathrm{C}$ & -23.10 & -8751.8 & -3780.70 \\
\hline
\end{tabular}

calculated, $25^{\circ} \mathrm{C} \quad-\mathbf{2 3 . 0 3} \pm \mathbf{1 . 1 8}$

calculated, $25^{\circ} \mathrm{C} \quad-\mathbf{2 2 . 9 0} \pm \mathbf{1 . 0 0}$

calculated, $5^{\circ} \mathrm{C} \quad-\mathbf{2 3 . 9 4} \pm \mathbf{1 . 5 0}$

calculated, $12^{\circ} \mathrm{C} \quad-\mathbf{2 3 . 7 5} \pm \mathbf{1 . 5 0}$

calculated, $20^{\circ} \mathrm{C} \quad-\mathbf{2 3 . 3 5} \pm \mathbf{1 . 5 0}$

measured $5^{\circ} \mathrm{C} \quad-\mathbf{2 2 . 3 0} \pm \mathbf{1 . 0 8}$

measured $20^{\circ} \mathrm{C} \quad \mathbf{- 2 2 . 9 7} \pm \mathbf{0 . 9 2}$

measured $40^{\circ} \mathrm{C} \quad \mathbf{- 2 4 . 2 8} \pm \mathbf{1 . 5 0}$
(Taylor et al., 1963a; Taylor et al., 1963b) (Racz and Soper, 1968) (Vieillard and Tardy, 1984) (La Iglesia, 2009) (Lobanov et al., 2013) (Lobanov et al., 2013) (Lobanov et al., 2013) (Bennett et al., 2017) 399.8 (Zhang et al., 2017)

ts (Taylor et al., 1963a; Taylor et al., 1963b)

ts (Racz and Soper, 1968)

ts (Lobanov, 2018; Lobanov et al., 2013)

ts (Lobanov, 2018; Lobanov et al., 2013)

ts (Lobanov, 2018; Lobanov et al., 2013) this study this study this study 
weighted mean at

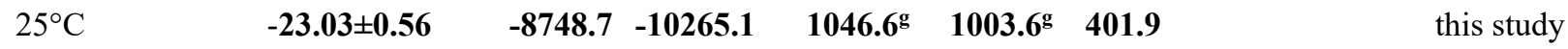

\footnotetext{
${ }^{\mathrm{a}}$ solubility products refer to reactions formulated with $\mathrm{H}^{+}, \mathrm{Mg}^{2+}, \mathrm{PO}_{4}{ }^{3-}$ and $\mathrm{H}_{2} \mathrm{O} ;{ }^{b}$ ts: calculated in this study using experimental data from the reference indicated; ${ }^{\mathrm{c}}$ not specified which solid had precipitated (Holt et al., 1954 ) in the paper; formation of MO4 assumed in the present study; ${ }^{\mathrm{d}} \mathrm{S}^{\circ}=650 \mathrm{~J} / \mathrm{mol} / \mathrm{K}$ fitted to describe the observed decrease of solubility with temperature, see Figure $5 .{ }^{e} \mathrm{C}_{\mathrm{p}}{ }^{\circ}$ obtained from $\Delta_{\mathrm{r}} \mathrm{C}_{\mathrm{p}}{ }^{\circ}=0$ for isocoulombic reaction: $\mathrm{Mg}_{3}\left(\mathrm{PO}_{4}\right)_{2}+4 \mathrm{H}_{2} \mathrm{O}_{\text {structural }} \Leftrightarrow \mathrm{Mg}_{3}\left(\mathrm{PO}_{4}\right)_{2} \cdot 4 \mathrm{H}_{2} \mathrm{O}$ (MO4) using $\mathrm{H}_{2} \mathrm{O}_{\text {structural }}\left(\mathrm{S}^{\circ}=40.2, \mathrm{~V}^{\circ}=13.7\right.$ and $\mathrm{C}_{\mathrm{p}}^{\circ}=$ 40.0) from (Helgeson et al., 1978); ${ }^{\mathrm{f}} \Delta_{\mathrm{r}} \mathrm{S}^{\circ}=\Delta_{\mathrm{r}} \mathrm{C}_{\mathrm{p}}{ }^{\circ}=0$ for isocoulombic reaction: $\mathrm{Mg}_{3}\left(\mathrm{PO}_{4}\right)_{2} \cdot 4 \mathrm{H}_{2} \mathrm{O}+4 \mathrm{H}_{2} \mathrm{O}_{\text {structural }}$ $\Leftrightarrow \mathrm{Mg}_{3}\left(\mathrm{PO}_{4}\right)_{2} \cdot 8 \mathrm{H}_{2} \mathrm{O}$ (bobierrite);

${ }^{\mathrm{g}} \Delta_{\mathrm{r}} \mathrm{S}^{\circ}=\Delta_{\mathrm{r}} \mathrm{C}_{\mathrm{p}}{ }^{\circ}=0$ for the isocoulombic reaction: $2 * \mathrm{MgKPO}_{4} \cdot 6 \mathrm{H}_{2} \mathrm{O}+\mathrm{MgO}-\mathrm{K}_{2} \mathrm{O}+10 \mathrm{H}_{2} \mathrm{O}_{\text {structural }} \Leftrightarrow$ $\mathrm{Mg}_{3}\left(\mathrm{PO}_{4}\right)_{2} \cdot 22 \mathrm{H}_{2} \mathrm{O}$ (cattiite); K-struvite used due to its structural similarity with cattiite.
}

Both the formation of MO4 and cattiite (MO22) was observed at $20^{\circ} \mathrm{C}$ as reported in Table 2 . The conditions under which preferentially $\mathrm{MO} 4$ or $\mathrm{MO} 22$ nucleate at $20^{\circ} \mathrm{C}$ remain presently unclear. However, experiments carried out at different temperatures (Table 3 ) showed that at $5^{\circ} \mathrm{C}$ only cattiite was observed to form, while at $40^{\circ} \mathrm{C}$ and above $\mathrm{MO} 4$ formed instead. This indicates a stabilisation of cattiite at low temperature, a comparable stability of cattiite and $\mathrm{MO} 4$ at $20^{\circ} \mathrm{C}$, while above $\mathrm{MO} 4$ is more stable. The experiments showed also that the solubility measured for MO4 (see Table 2 and Table 3) decreased from -23.0 at $20^{\circ} \mathrm{C}$ to -31.2 at $80^{\circ} \mathrm{C}$ for $\log \mathrm{K}_{\text {so }}$ as shown in Figure $5 \mathrm{C}$. From these data a solubility product -23.5 was derived for $25^{\circ} \mathrm{C}$, while the decrease of its solubility with temperature was well described with an entropy value of $650 \pm 200 \mathrm{~J} / \mathrm{mol} / \mathrm{K}$. This entropy is higher than entropy value $(339 \mathrm{~J} / \mathrm{mol} / \mathrm{K})$ estimated from farringtonite and structural water, which did not well describe the decrease in solubility with temperature. Solubility products for magnesium orthophosphate tetrahydrate (MO4) have not yet been explicitly been reported in the literature. However, Holt et al. (Holt et al., 1954) reported the formation of an unspecified magnesium orthophosphate at $38^{\circ} \mathrm{C}$ (possibly $\mathrm{MO} 4$ ) and (Lobanov, 2018; Lobanov et al., 2013) observed at $85^{\circ} \mathrm{C}$ in samples containing dittmarite and bobierrite the destabilisation of bobierrite to MO4. The solubility products derived from those measurements are in line with the calculated solubility of MO4 in this paper as shown in Figure 5C.

For cattiite a solubility product of -22.97 at $20^{\circ} \mathrm{C}$ has been derived from the measured data, a solubility comparable to MO4 at this temperature, explaining the observation of both, MO4 and MO22, at the experiments carried out at $20^{\circ} \mathrm{C}$. At $5^{\circ} \mathrm{C}$ a slightly higher solubility was measured for $\mathrm{MO} 22$, 
while at $40^{\circ} \mathrm{C}$, cattiite was destabilised in one of the samples (Cat_5), while a somewhat lower solubility was obtained from the other sample (Cat_D), where also an unidentified phase had been observed with a main reflection at $7.1^{\circ} 2 \theta \mathrm{CoK} \alpha(\mathrm{d}$ value $=14.4 \AA)$ in $\mathrm{XRD}$. The data measured in this paper for cattiite compare well with the solubility product of $\log \mathrm{K}_{\mathrm{SO}}$ of -22.9 to -23.0 at $25^{\circ} \mathrm{C}$ obtained from literature data (Racz and Soper, 1968; Taylor et al., 1963a; Taylor et al., 1963b) as shown in Figure 5C; these data showed no significant variation with temperature. The thermodynamic dataset selected in Table 7 for cattiite describes the measured solubility adequately as illustrated in Figure 5C. The different temperature behaviour of the $\mathrm{MO} 4$ and $\mathrm{MO} 22$ is consistent with the presence of $\mathrm{MO} 22$ at low temperatures and of MO4 at higher temperatures as summarised in Table 2 and Table 3.

The formation of bobierrite was observed only in the presence of potassium or calcium at $20^{\circ} \mathrm{C}$ to $90^{\circ} \mathrm{C}$ (see the experiments Bob1, Bob2, and MO4 in Table 1 and Table 3). In the absence of calcium or potassium, MO4 formed instead even at $90^{\circ} \mathrm{C}$. However, once formed, bobierrite remained stable in the temperature range 20 to $90{ }^{\circ} \mathrm{C}$ as observed in the re-dissolution experiments using pre-synthesised bobierrite reported in Table 3. Similarly, (Bennett et al., 2017) has observed the formation of bobierrite in samples containing potassium, (Lobanov, 2018; Lobanov et al., 2013) in the presence of ammonium, while (Taylor et al., 1963a) reported the destabilisation of cattiite to the more stable bobierrite at $25^{\circ} \mathrm{C}$ within a week in the presence of ammonium. (Racz and Soper, 1968) observed in the presence of sodium only MO22 but no bobierrite formation. Together these data seem to indicate that bobierrite is stable at ambient and higher temperatures, but that its formation is kinetically hindered and that the presence of $\mathrm{K}$, ammonium or Ca seems to ease bobierrite nucleation, due to reasons unknown.

In this study bobierrite solubility was measured from the dissolution of bobierrite synthesized at $90^{\circ} \mathrm{C}$. The data are summarised in Table 7 and Figure 5 and show a strong decrease of its solubility with temperature, a trend which is mirrored in the solubility products calculated from the data of (Lobanov, 2018; Lobanov et al., 2013). From the data reported in Table 7, a $\log \mathrm{K}_{\mathrm{SO}}=-25.3$ at $25^{\circ} \mathrm{C}$ was derived for bobierrite; its decrease with temperature is again well described by the entropy of $801 \mathrm{~J} / \mathrm{mol} / \mathrm{K}$ estimated from MO4 and structural water. The solubility of bobierrite $\left(\mathrm{Mg}_{3}\left(\mathrm{PO}_{4}\right)_{2} \cdot 8 \mathrm{H}_{2} \mathrm{O}\right)$ has also been measured by (Taylor et al., 1963a; Taylor et al., 1963b) at $25^{\circ} \mathrm{C}$, where bobierrite had formed in solutions 
originally equilibrated with cattiite $\left(\mathrm{Mg}_{3}\left(\mathrm{PO}_{4}\right)_{2} \cdot 22 \mathrm{H}_{2} \mathrm{O}\right)$, indicating a higher stability of bobierrite than of cattiite. In fact, the data plotted in Figure 5B and $\mathrm{C}$ indicate that bobierrite is more stable than cattiite and $\mathrm{MO} 4$ in the temperature range of $10^{\circ} \mathrm{C}$ to approximately $90^{\circ} \mathrm{C}$, which agrees with the destabilisation of cattiite to bobierrite observed by (Taylor et al., 1963a; Taylor et al., 1963b) at $25^{\circ} \mathrm{C}$. At temperatures above $90^{\circ} \mathrm{C} \mathrm{MO} 4$ is predicted to be slightly more stable than bobierrite; the difference however, is small in agreement with the observations of both $\mathrm{MO} 4$ and $\mathrm{MO} 8$ at 80 and $90^{\circ} \mathrm{C}$.

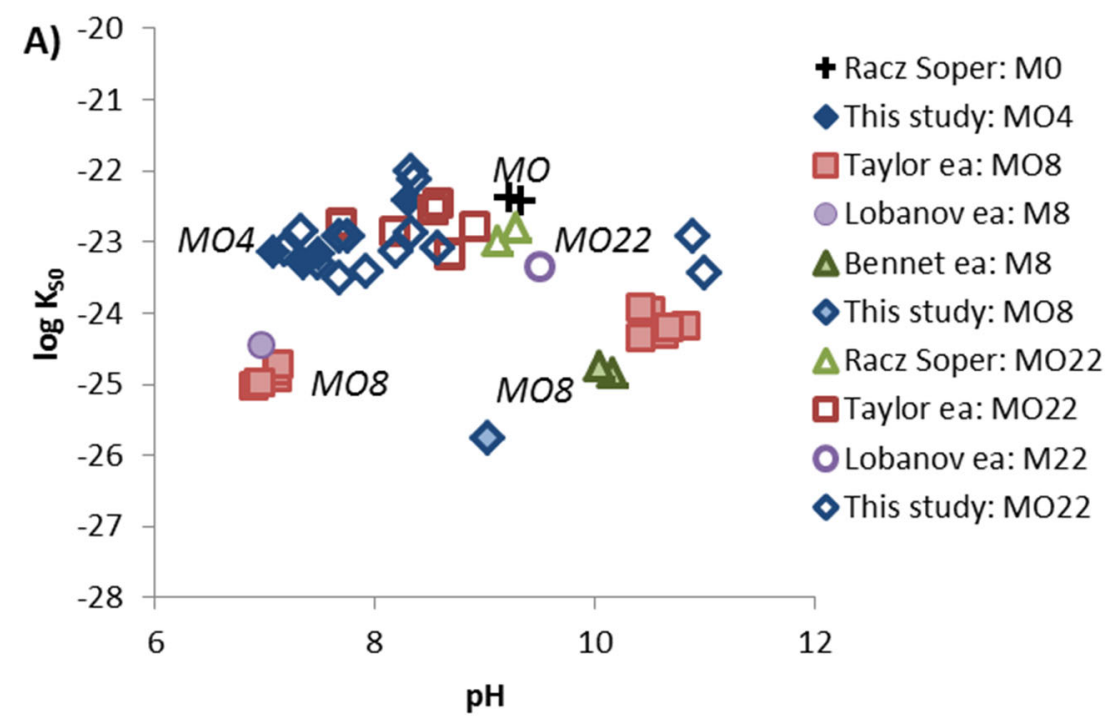



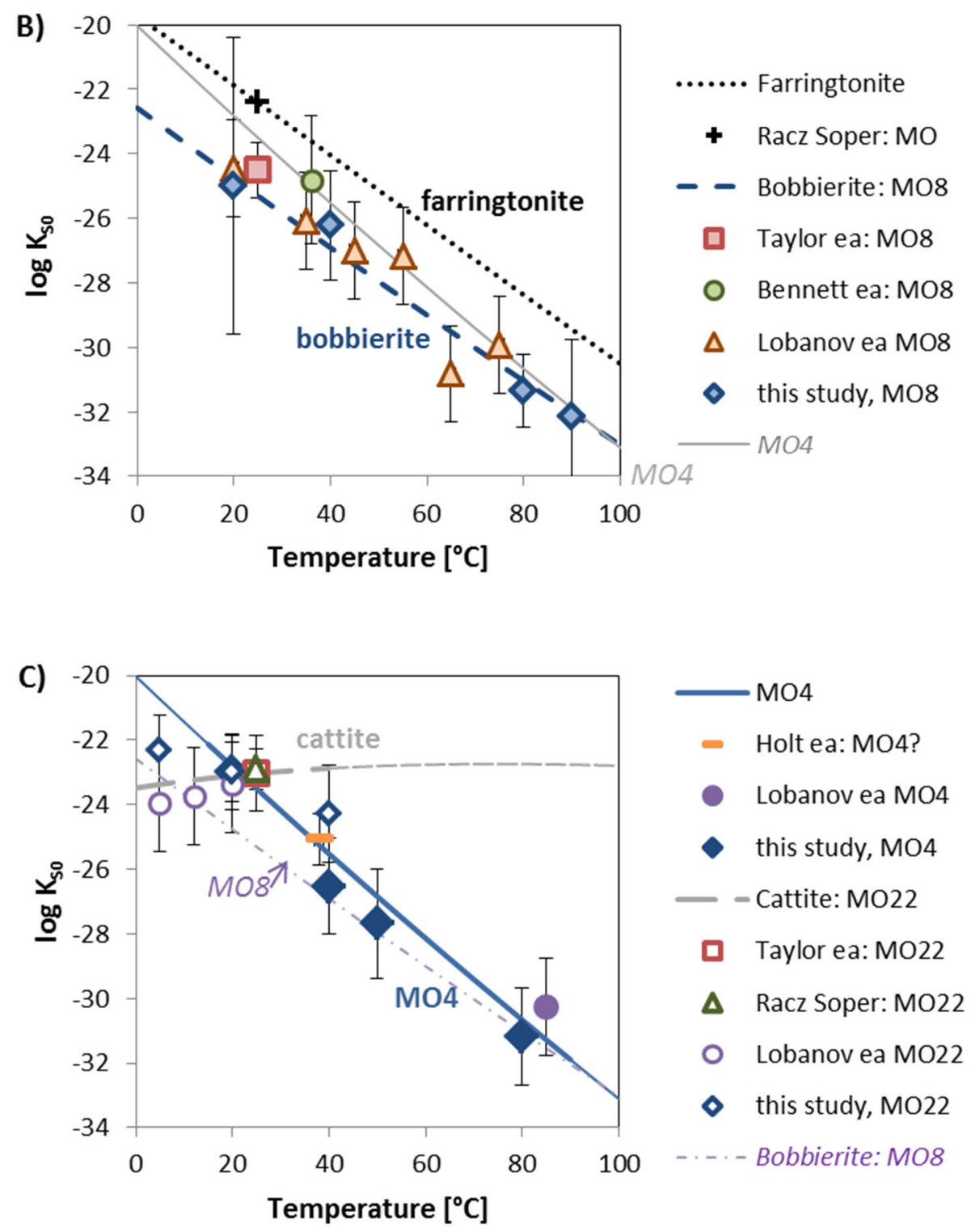

Figure 5: Calculated solubility products for magnesium orthophosphates (farringtonite: MO, magnesium orthophosphates tetrahydrate: MO4, bobierrite: MO8 and cattiite: MO22; $\left.\left.\mathrm{Mg}_{3}\left(\mathrm{PO}_{4}\right)_{2} \cdot \mathrm{xH}_{2} \mathrm{O} \Leftrightarrow 3 \mathrm{Mg}^{2+}+2 \mathrm{PO}_{4}{ }^{3-}+\mathrm{xH}_{2} \mathrm{O}\right) \mathrm{A}\right)$ at $20-25^{\circ} \mathrm{C}$ as a function of $\mathrm{pH}$, and $\left.\mathrm{B}, \mathrm{C}\right)$ as a function of temperature. Recalculated using measured concentrations from this study (Bennett et al., 2017; Holt et al., 1954; Lobanov, 2018; Lobanov et al., 2013; Racz and Soper, 1968; Taylor et al., 1963a; Taylor et al., 1963b) as a function of temperature. The lines indicate the solubility calculated from the thermodynamic data summarized in Table 5.

The solubility trends plotted in Figure $5 \mathrm{~B}$ and $\mathrm{C}$ indicate that the formation of cattiite is more probable at low temperature, bobierrite at intermediate temperatures, while magnesium orthophosphate tetrahydrate can be expected above $90^{\circ} \mathrm{C}$. The comparable stability of MO4 $\left(\log \mathrm{K}_{\mathrm{SO}}=-23.0\right)$ and cattiite $\left(\log \mathrm{K}_{\mathrm{SO}}=-23.0\right)$ at $20^{\circ} \mathrm{C}$ leads to the formation of both solids at this temperature, while at lower temperature cattiite is more stable and MO4 at higher temperature. Bobierrite formation is kinetically 
hindered in the absence of potassium, ammonium or calcium, in particular at lower temperatures, although bobierrite is thermodynamically the most stable magnesium orthophosphate at ambient temperature.

\section{Application of thermodynamic data to hydrated MKP cements}

Based on the thermodynamic data established above and compiled in Table 5, the effect of $\mathrm{Mg} / \mathrm{PO}_{4}$, water to solid ratio, $\mathrm{pH}$, and temperature on the stable hydrates and pore solution composition is calculated and compared to the experimental results in the following section.

\subsection{Effect of $\mathrm{pH}$ on aqueous and solid phase composition}

The effect of $\mathrm{pH}$ on the hydrates formed and the solution composition was studied on solids prepared from $\mathrm{MgCl}_{2}$ and $\mathrm{KH}_{2} \mathrm{PO}_{4}$, as the presence of chlorides allowed studying also low $\mathrm{pH}$ values. Thermodynamic modelling using the data compiled in Table 5 indicates that below a $\mathrm{pH}$ value of 7.8 only newberyite $\left(\mathrm{MgHPO}_{4} \cdot 3 \mathrm{H}_{2} \mathrm{O}\right)$ is expected to form as shown in Figure 6. In this range a pH increase is accompanied by a parallel decrease of both magnesium and phosphate concentrations as only one phase, $\mathrm{MgHPO}_{4} \cdot 3 \mathrm{H}_{2} \mathrm{O}$, is calculated to precipitate. Between $\mathrm{pH} 7.8$ to 9.1 , magnesium orthophosphates are predicted to precipitate, at $\mathrm{pH}$ values above $8.0 \mathrm{~K}$-struvite replaces newberyite and brucite occurs at $\mathrm{pH}$ above 10.5. The general trends of the measured concentrations and the sequence at which the solids occur agree generally well with the experimental observations as shown in Figure 6C. The only significant difference is that experimentally magnesium orthophosphate were observed at lower $\mathrm{pH}$ values (7.1 and 7.4) than predicted ( $\mathrm{pH} 7.8)$. However, even a small variation of the solubility products by $\pm 0.2 \log$ units (see Figure 6 ) lowered that to $\mathrm{pH} 7.4$, illustrating the sensitivity of the systems to the thermodynamic data derived. Whether the formation of magnesium orthophosphate tetrahydrate $\left(\mathrm{Mg}_{3}\left(\mathrm{PO}_{4}\right)_{2} \cdot 4 \mathrm{H}_{2} \mathrm{O}\right)$ or cattiite $\left(\mathrm{Mg}_{3}\left(\mathrm{PO}_{4}\right)_{2} \cdot 22 \mathrm{H}_{2} \mathrm{O}\right)$ was allowed, led to no significant differences in the aqueous concentrations; the variations were well within the uncertainty of at least $0.2 \log$ units in experimental solubility products as shown in Figure 6. The calculations indicated, however, rather the formation of $\mathrm{Mg}_{3}\left(\mathrm{PO}_{4}\right)_{2} \cdot 22 \mathrm{H}_{2} \mathrm{O}$, which has a slightly higher stability at $20^{\circ} \mathrm{C}$, than of $\mathrm{Mg}_{3}\left(\mathrm{PO}_{4}\right)_{2} \cdot 4 \mathrm{H}_{2} \mathrm{O}$. 
$\mathrm{Mg}_{2} \mathrm{KH}\left(\mathrm{PO}_{4}\right)_{2} \cdot 15 \mathrm{H}_{2} \mathrm{O}$ was calculated to be absent in agreement with the experiments, but was only little undersaturated (0.05 log units) between $\mathrm{pH} 7.5$ to 8.1. 


Figure 6: A) Aqueous concentrations as a function of $\mathrm{pH}$ in solutions with $50 \mathrm{mM} \mathrm{Mg}, 50 \mathrm{mM}$ phosphate, $100 \mathrm{mM}$ chloride and increasing amounts of potassium hydroxide at $20^{\circ} \mathrm{C}$ : solid lines: calculated concentrations (darker lines: MO 22, lighter lines: MO4 (MO22 formation supressed); dotted and dashed lines: variation of solubility products by $\pm 0.2 \log$ units; symbols: measured values from Table 2. The formation of bobierrite has been supressed in the calculations as its formation at $20^{\circ} \mathrm{C}$ is kinetically hindered. * This experiment contained $200 \mathrm{mM} \mathrm{K}$ and $\mathrm{Cl}$. B) Calculated amount of solid phases; the shadowed areas indicate the $\mathrm{pH}$ of the samples shown. C) XRD of samples 1_43, 1_86L, 1_86M and 1_86H after 60 and 750 days (Solid lines: 60 days; dashed (red) line: 750 days). N: $\mathrm{MgHPO}_{4} \cdot 3 \mathrm{H}_{2} \mathrm{O} ; 4: \mathrm{Mg}_{3}\left(\mathrm{PO}_{4}\right)_{2} \cdot 4 \mathrm{H}_{2} \mathrm{O} ; \mathrm{S}: \mathrm{MgKPO}_{4} \cdot 6 \mathrm{H}_{2} \mathrm{O} ; *$ unidentified phase(s) (UP1).

The formation of newberyite at low $\mathrm{pH}$ values and its destabilisation at higher $\mathrm{pH}$ values agrees with the observations of (Le Rouzic et al., 2017a), who observed in solutions containing $800 \mathrm{mM}$ chloride the formation of newberyite at $\mathrm{pH} 5$ to 7 and of $\mathrm{K}$-struvite at $\mathrm{pH} 7$ and 8.

The sequence of stabilisation with $\mathrm{pH}$ (newberyite at low $\mathrm{pH}$ values, $\mathrm{Mg}_{3}\left(\mathrm{PO}_{4}\right)_{2} \cdot 4 \mathrm{H}_{2} \mathrm{O}$, $\mathrm{Mg}_{3}\left(\mathrm{PO}_{4}\right)_{2} \cdot 22 \mathrm{H}_{2} \mathrm{O}$ or $\mathrm{Mg}_{2} \mathrm{KH}\left(\mathrm{PO}_{4}\right)_{2} \cdot 15 \mathrm{H}_{2} \mathrm{O}$ at intermediate $\mathrm{pH}$ values and $\mathrm{K}$-struvite at high $\mathrm{pH}$ values and high $\mathrm{K}$ concentrations) corresponds to the sequence of phases formed during the reaction of magnesium potassium phosphate cements (Chau et al., 2012; Le Rouzic et al., 2017a; Xu et al., 2018a; $\mathrm{Xu}$ et al., 2019). The early reaction of magnesium phosphate cements starts at $\mathrm{pH}$ values below 6 , i.e. under conditions where newberyite can be expected to form, whose formation is in fact observed during the first minutes of the reaction of magnesium phosphate cements (Chau et al., 2012; Le Rouzic et al., 2017a; Xu et al., 2019). After 5 to 10 minutes, the formation of $\mathrm{Mg}_{2} \mathrm{KH}\left(\mathrm{PO}_{4}\right)_{2} \cdot 15 \mathrm{H}_{2} \mathrm{O}$ was observed in systems with high water to solid ratios (suspensions) (Chau et al., 2012; Le Rouzic et al., 2017a; Xu et al., 2018a; $\mathrm{Xu}$ et al., 2019), at intermediate $\mathrm{pH}$ values of 7 to 8 . The further reaction of magnesium phosphate cements is accompanied by a further $\mathrm{pH}$ rise where $\mathrm{K}$-struvite is the main hydrate formed.

\subsection{Effect of the magnesium to phosphate molar ratio}

Figure 7A illustrates how the increase of the $\mathrm{Mg} / \mathrm{PO}_{4}$ affects the composition of the aqueous phase; potassium, phosphate and magnesium concentrations decrease at higher $\mathrm{Mg} / \mathrm{PO}_{4}$, while hydroxide concentrations and thus the $\mathrm{pH}$ values increase strongly. The magnesium to phosphate ratio influences also the hydrates formed as shown in Figure 7B. At $\mathrm{Mg} / \mathrm{PO}_{4}<0.5$ the formation of newberyite only $\left(\mathrm{MgHPO}_{4} \cdot 3 \mathrm{H}_{2} \mathrm{O}\right)$ is predicted, between $\mathrm{Mg} / \mathrm{PO}_{4} 0.5$ to 0.7 catiite plus K-struvite (or possibly $\left.\mathrm{Mg}_{2} \mathrm{KH}\left(\mathrm{PO}_{4}\right)_{2} \cdot 15 \mathrm{H}_{2} \mathrm{O}\right)$ are calculated, while at higher $\mathrm{Mg} / \mathrm{PO}_{4} \mathrm{~K}$-struvite plus minor amounts of cattiite 
and brucite are calculated. The experimental observations in Figure $7 \mathrm{C}$ show the same trends. At $\mathrm{Mg} / \mathrm{PO}_{4}=0.7$, the presence of $\mathrm{Mg}_{2} \mathrm{KH}\left(\mathrm{PO}_{4}\right)_{2} \cdot 15 \mathrm{H}_{2} \mathrm{O}$ was observed at intermediate times (60 days; Table 2), which was destabilised to K-struvite, some newberyite and unidentified phase(s) after long hydration times. At $\mathrm{Mg} / \mathrm{PO}_{4}=1$, cattiite and $\mathrm{K}$-struvite were observed after 750 days, but no or only very low amounts of cattiite were present after 60 days. The main difference was observed at high $\mathrm{Mg} / \mathrm{PO}_{4}=1.5$, where no cattiite was observed experimentally but only K-struvite and some brucite.

A comparison of Figure 6 and Figure 7 shows that an increase of the $\mathrm{Mg} / \mathrm{PO}_{4}$ and of $\mathrm{pH}$ have a comparable effect on the hydrates and the composition of the solution; $\mathrm{Mg}$ and phosphate concentrations decrease and K-struvite instead of newberyite is formed. The same sequence from low to high $\mathrm{Mg} / \mathrm{PO}_{4}$, from low to high $\mathrm{pH}$ and from newberyite to $\mathrm{K}$-struvite is also observed during the reaction of MKP cements (Lahalle et al., 2018; Lahalle et al., 2016; Le Rouzic et al., 2017a; Le Rouzic et al., 2017b; Xu et al., 2019). The dissolution of $\mathrm{KH}_{2} \mathrm{PO}_{4}$ in MKP cements occurs very fast within less than a minute, while reaction of $\mathrm{MgO}$ is slower and only partial, such that a hydrating MKP cement has initially a very low $\mathrm{Mg} / \mathrm{PO}_{4}$, which increases with time. This slow reaction of $\mathrm{MgO}$ leads initially to low $\mathrm{pH}$ values and a low availability of magnesium, resulting in the formation of $\mathrm{MgHPO}_{4} \cdot 3 \mathrm{H}_{2} \mathrm{O}$ (newberyite) and $\mathrm{Mg}_{2} \mathrm{KH}\left(\mathrm{PO}_{4}\right)_{2} \cdot 15 \mathrm{H}_{2} \mathrm{O}$, which react to $\mathrm{K}$-struvite only with time (Chau et al., 2012; Lahalle et al., 2018; Lahalle et al., 2016; Le Rouzic et al., 2017a; Le Rouzic et al., 2017b; Xu et al., 2018a; Xu et al., 2019) 




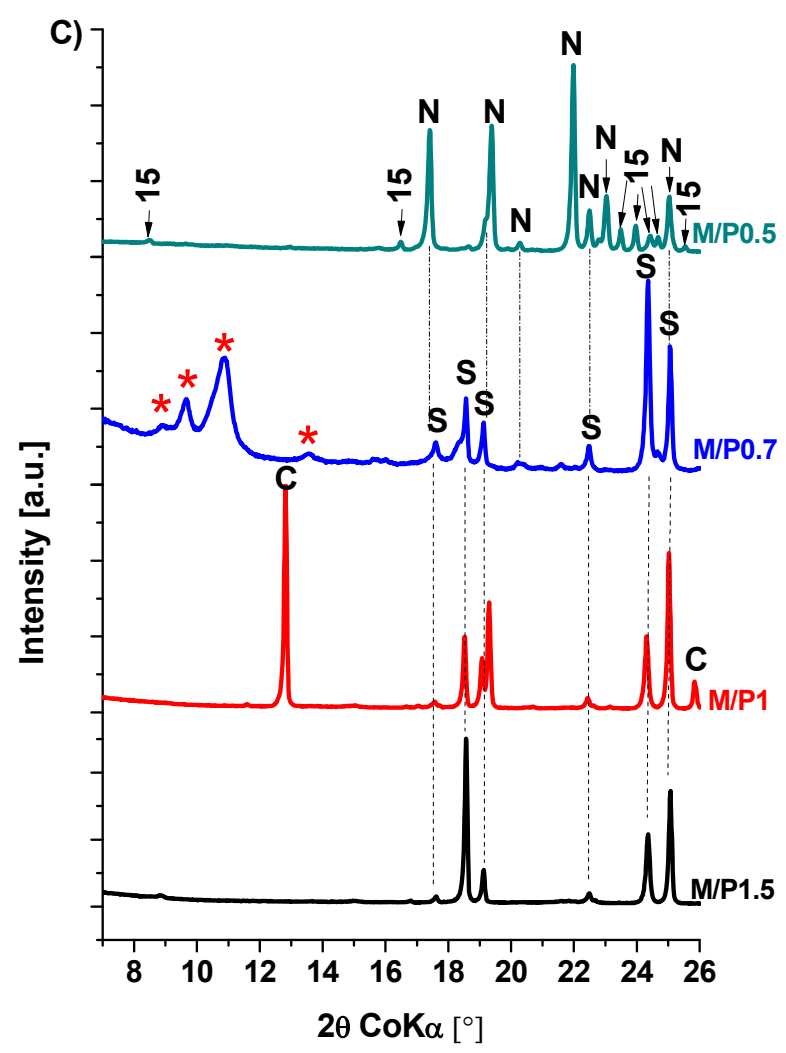

Figure 7: A) Aqueous concentrations as a function of the total $\mathrm{Mg} / \mathrm{PO}_{4}$ at high water to solid ratios in solutions with $100 \mathrm{mM}$ potassium and phosphate and 50 to $150 \mathrm{mM}$ magnesium at $20^{\circ} \mathrm{C}$ : solid lines: calculated concentrations; dotted and dashed lines: variation of solubility products by $\pm 0.2 \log$ units; symbols: measured values; full symbols: Samples 0.5_64, 0.7_61, 1_57 and 1.5_51 after 480 or 750 days; empty symbols: Samples 0.5_64, 0.6_62, 0.7_61, 0.8_59, 1_57 and 1.5_51 after 60 day. The formation of bobierrite has been supressed in the calculations as its formation at $20^{\circ} \mathrm{C}$ was kinetically hindered. B) Calculated amount of solid phases; the shadowed areas indicate the composition of the samples shown. C) XRD of samples 0.5_64 (750 days), 0.7_61 (480 days), 1_57 (750 days) and 1.5_51 (480 days). C: $\mathrm{Mg}_{3}\left(\mathrm{PO}_{4}\right)_{2} \cdot 22 \mathrm{H}_{2} \mathrm{O} ; \mathrm{N}: \mathrm{MgHPO}_{4} \cdot 3 \mathrm{H}_{2} \mathrm{O} ; \mathrm{S}: \mathrm{MgKPO}_{4} \cdot 6 \mathrm{H}_{2} \mathrm{O} ; 15$ :

$\mathrm{Mg}_{2} \mathrm{KH}\left(\mathrm{PO}_{4}\right)_{2} \cdot 15 \mathrm{H}_{2} \mathrm{O}$. *: unidentified phase(s): UP1.

\subsection{Effect of the water to solid ratio}

In addition to $\mathrm{pH}$ and the $\mathrm{Mg} / \mathrm{PO}_{4}$ ratio also the water to solid ratio plays an important role and affects the aqueous and solid phase composition as shown in Figure 8 for samples with $\mathrm{Mg} / \mathrm{PO}_{4}$ ratio $=$ 1. K-struvite is calculated to be stable at all water solid ratios investigated; its content is calculated to decrease at high water to solid ratios. An increase of water to solid ratio lowers the potassium, magnesium and phosphate concentrations, while the $\mathrm{pH}$ increases. The lowering of the K-concentrations stabilises cattiite, $\mathrm{Mg}_{3}\left(\mathrm{PO}_{4}\right)_{2} \cdot 22 \mathrm{H}_{2} \mathrm{O}$, at higher w/s leading to a stronger decrease of magnesium and phosphate concentrations than of $\mathrm{K}$ and thus to higher $\mathrm{pH}$ values. At very low water to solids ratio the 
presence of a low amount of either newberyite or $\mathrm{Mg}_{2} \mathrm{KH}\left(\mathrm{PO}_{4}\right)_{2} \cdot 15 \mathrm{H}_{2} \mathrm{O}$ is calculated. The measured concentrations after long reaction times (solid symbols) agree well with the calculated trends as shown in Figure 8A, while the measured data after 60 days (empty symbols) show higher potassium, phosphate and magnesium concentrations, due to slow reaction of the $\mathrm{MgO}$, leading to lower effective $\mathrm{Mg} / \mathrm{PO}_{4}$ ratios at early times. The XRD data in Figure $8 \mathrm{C}$ confirm the predominance of K-struvite and the presence of cattiite at high water to solid ratio. $\mathrm{Mg}_{2} \mathrm{KH}\left(\mathrm{PO}_{4}\right)_{2} \cdot 15 \mathrm{H}_{2} \mathrm{O}$ was not observed after long reaction times at w/s 5 or 10, but traces were present after 60 days.

In MKP cements with much higher nominal $\mathrm{Mg} / \mathrm{PO}_{4}$ ratios, the same trends have been observed as in our simplified suspensions. A low water to solid ratio leads to higher potassium, magnesium and phosphate concentrations and promotes the formation of K-struvite in MKP cements (Lahalle et al., 2018; Xu et al., 2018a; Xu et al., 2019). 

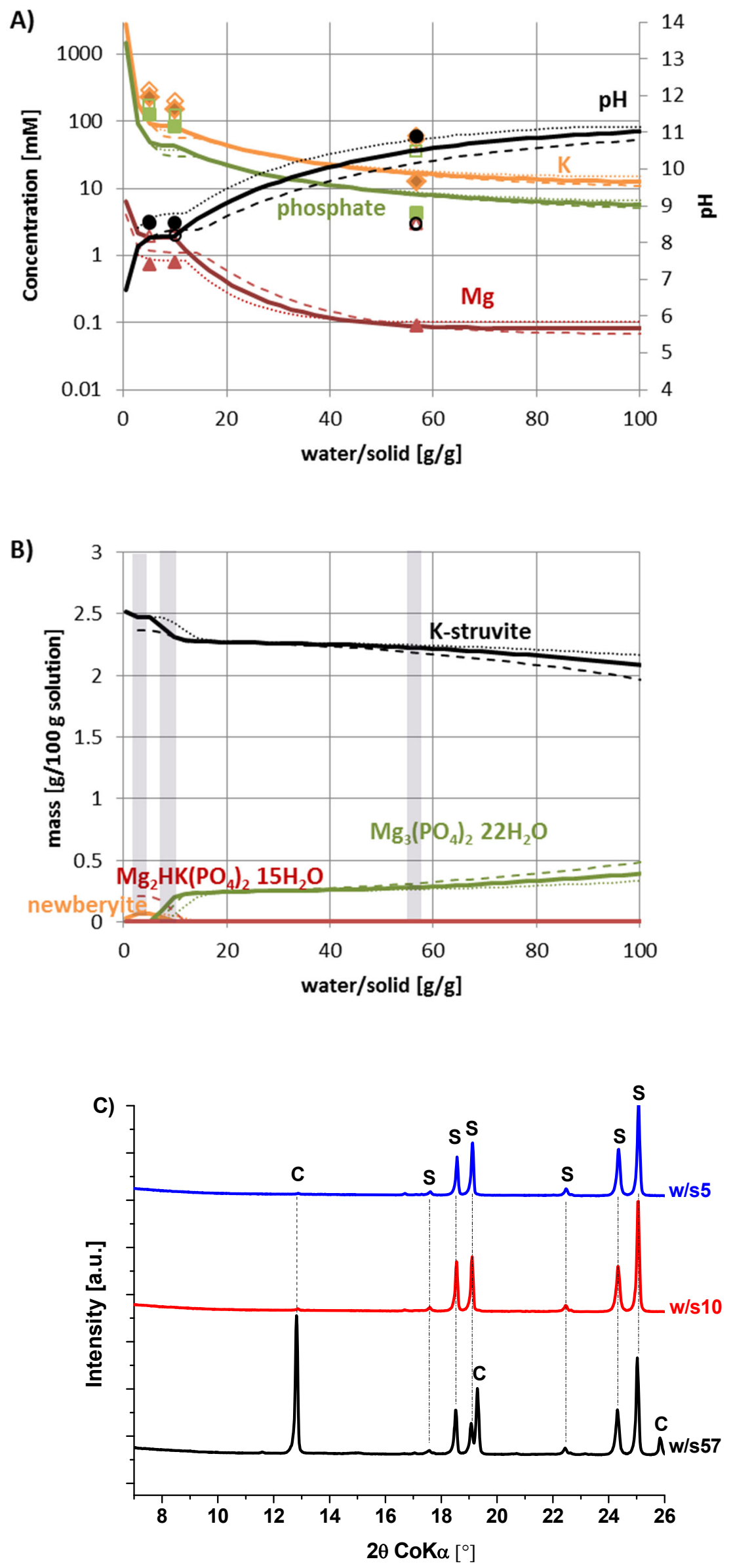
Figure 8: A) Aqueous concentrations as a function of the water/solid ratio at $\mathrm{Mg} / \mathrm{PO}_{4}=1$ in solutions at $20^{\circ} \mathrm{C}$ : solid lines: calculated concentrations; dotted and dashed lines: variation of solubility products by $\pm 0.2 \log$ units; symbols: measured values; full symbols: Samples 1_57, 1_10 and 1_5 after 480 or 750 days; empty symbols: Samples 1_57, 1_10 and 1_5 1 after 60 or 75 days. The formation of bobierrite has been supressed in the calculations as its formation at $20^{\circ} \mathrm{C}$ was kinetically hindered. B) Calculated amount of solid phases; the shadowed areas indicate the composition of the samples shown. C) XRD of samples 1_57 (750 days), 1_10 (480 days) and 1_5 (480 days). C: $\mathrm{Mg}_{3}\left(\mathrm{PO}_{4}\right)_{2} \cdot 22 \mathrm{H}_{2} \mathrm{O} ; \mathrm{S}: \mathrm{MgKPO}_{4} \cdot 6 \mathrm{H}_{2} \mathrm{O}$.

\subsection{Effect of reaction temperature}

Also the temperature affects the stable hydrates as illustrated below for K-struvite re-dissolved in water and for samples with $\mathrm{Mg} / \mathrm{PO}_{4}$ ratio of 0.5 and 1 .

The dissolution of K-struvite in water and equilibration at 20,40 and $80^{\circ} \mathrm{C}$ resulted in the formation of both cattiite and K-struvite at $20^{\circ} \mathrm{C}$, of K-struvite and $\mathrm{MgKPO}_{4} \cdot \mathrm{H}_{2} \mathrm{O}$ at $40^{\circ} \mathrm{C}$ and of bobierrite at $80^{\circ} \mathrm{C}$ as summarised in Table 3 and Figure 9C. For a sample which contained initially cattiite only, similar observations could be made; cattiite remained stable at $20^{\circ} \mathrm{C}$, bobierrite was formed instead at $40^{\circ} \mathrm{C}$, while at $80^{\circ} \mathrm{C} \mathrm{MO} 4$ precipitated (Table 3). Thus in both cases it was observed that cattiite destabilises at above $20^{\circ} \mathrm{C}$ in agreement with the calculated relative stability in Figure $5 \mathrm{C}$. As the solubilities of bobierrite and MO4 are very similar between 40 and $80^{\circ} \mathrm{C}$ (Figure $5 \mathrm{~B}$ and $\mathrm{C}$ ), both of the solids seem to nucleate at $40^{\circ} \mathrm{C}$, without any clear preference. K-struvite is destabilised at higher temperature; less K-struvite is observed at $40^{\circ} \mathrm{C}$ than at $20^{\circ} \mathrm{C}$, and none at $80^{\circ} \mathrm{C}$ (Figure $9 \mathrm{C}$, Table 3). At $40^{\circ} \mathrm{C}$ the formation of $\mathrm{MgKPO}_{4} \cdot \mathrm{H}_{2} \mathrm{O}$ is observed, indicated by an additional reflection at $12.5^{\circ} 2 \theta \mathrm{CoK} \alpha$ and a broadening and increased intensity of the reflections at $22.4^{\circ}$ and $25.0^{\circ} 2 \theta \mathrm{CoK} \alpha$ (Figure 9C).

Thermodynamic modelling using the data selected in this paper reproduces the trends in aqueous concentrations and solid phases well as shown in Figure 9A and B. Modelling, however, predicts the destabilisation of K-struvite at slightly lower temperatures (at $25 \pm 15^{\circ} \mathrm{C}$ ) than observed in the experiments as well as the formation of MO4 or bobbierite at below $40^{\circ} \mathrm{C}$. 

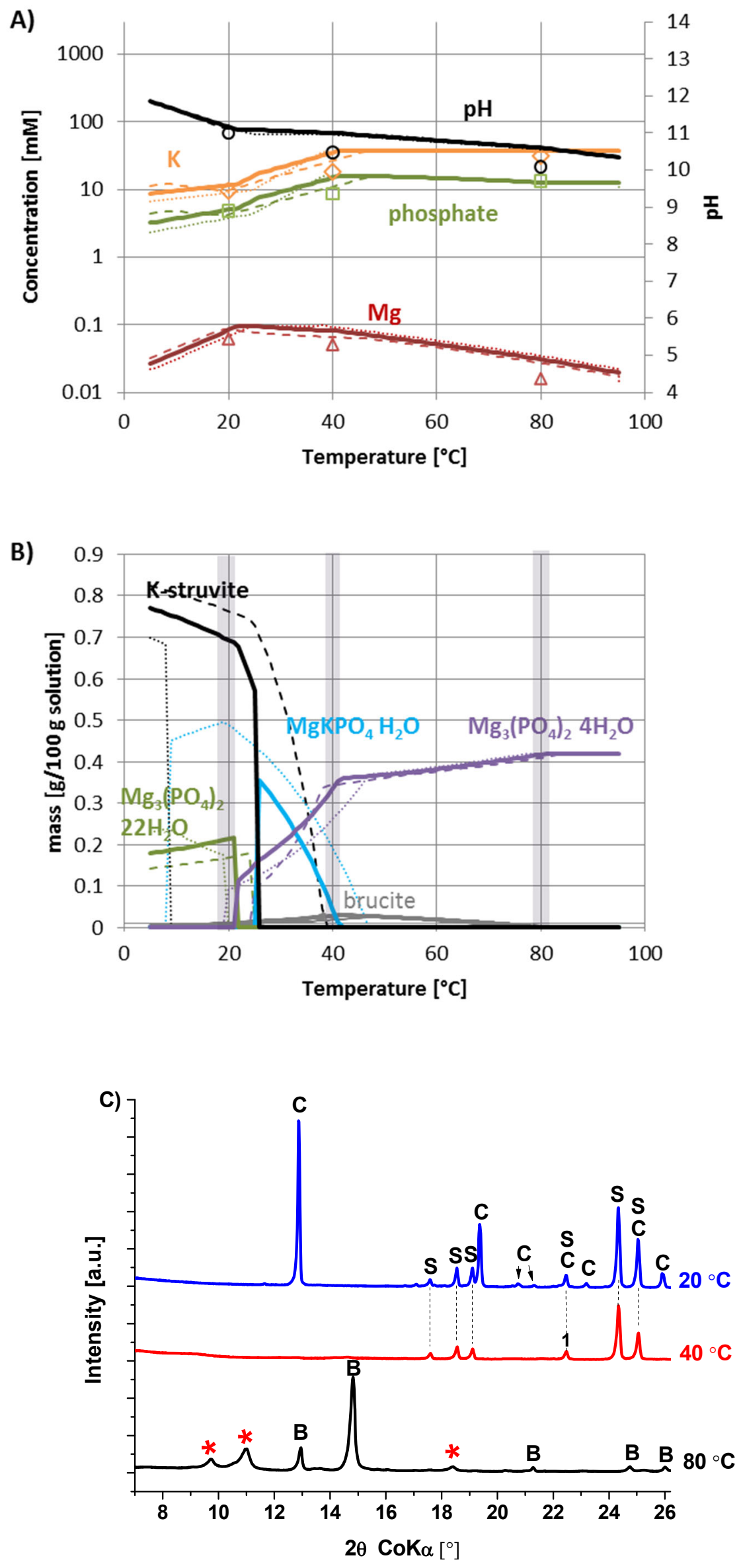
Figure 9: A) Aqueous concentrations as a function of temperature for K-struvite dissolved in water at 20,40 and $80^{\circ} \mathrm{C}$ and equilibrated for 30 days: solid lines: calculated concentrations; dotted and dashed lines: variation of solubility products by $\pm 0.2 \log$ units; empty symbols: measured values. The formation of bobierrite has been supressed in the calculations as its formation at $20^{\circ} \mathrm{C}$ was kinetically hindered. B) Calculated amount of solid phases; the shadowed areas indicate the temperature of the samples shown. C) XRD of after 30 days of reaction. $\mathrm{B}: \mathrm{Mg}_{3}\left(\mathrm{PO}_{4}\right)_{2} \cdot 8 \mathrm{H}_{2} \mathrm{O} ; \mathrm{C}: \mathrm{Mg}_{3}\left(\mathrm{PO}_{4}\right)_{2} \cdot 22 \mathrm{H}_{2} \mathrm{O} ; \mathrm{S}$ : $\mathrm{MgKPO}_{4} \cdot 6 \mathrm{H}_{2} \mathrm{O} ; 1: \mathrm{MgKPO}_{4} \cdot \mathrm{H}_{2} \mathrm{O}$; *: unidentified phase (UP1).

For samples with $\mathrm{Mg} / \mathrm{PO}_{4}=1$ (sample 1_57) similar observations were made (Figure 10C): at $5^{\circ} \mathrm{C}$ and $20^{\circ} \mathrm{C}$ cattiite and $\mathrm{K}$-struvite dominated the solid phases. At early ages (30 or 60 days) in addition some $\mathrm{Mg}_{2} \mathrm{KH}\left(\mathrm{PO}_{4}\right)_{2} \cdot 15 \mathrm{H}_{2} \mathrm{O}$ was present (Table 3), which was destabilised after 1 and 2 years. At $50^{\circ} \mathrm{C}$, again cattiite is destabilised while some $\mathrm{K}$-struvite, $\mathrm{MgKPO}_{4} \cdot \mathrm{H}_{2} \mathrm{O}$ and $\mathrm{MO} 4$ are observed, at $80^{\circ} \mathrm{C} \mathrm{MO} 4$ was identified as summarised in Table 3 and Figure 10C. In addition, at 50 and $80^{\circ} \mathrm{C}$ also unidentified phase(s) with main reflections at $9.8^{\circ}$ and $11.0^{\circ} 2 \theta \mathrm{CoK} \alpha(\mathrm{d}$-values $=10.4 \AA$ and $9.4 \AA)$ was observed, which could not be assigned to any known structure. Mass balance calculations indicated for this unidentified phase an approximate total composition of $\mathrm{K}_{0-0.3} \mathrm{Mg}_{1.5-2} \mathrm{PO}_{4} \cdot 4-5 \mathrm{H}_{2} \mathrm{O}$.

The destabilisation of K-struvite and cattiite at higher temperature led to an increase of the phosphate concentrations, magnesium concentrations decreased with temperature, while potassium concentration did not vary significantly between $50^{\circ} \mathrm{C}$ (where $\mathrm{K}$-struvite is present) and $80^{\circ} \mathrm{C}$ where no $\mathrm{K}$-struvite was observed (Figure 10A, Table 3). Both at 50 and $80^{\circ} \mathrm{C}$ the measured $\mathrm{K}$-concentrations are with 59 to 79 $\mathrm{mM}$ significantly lower than the maximum K-concentrations of $179 \mathrm{mM}$, indicating the presence of a potassium-containing solid (possible some $\mathrm{MgKPO}_{4} \cdot \mathrm{H}_{2} \mathrm{O}$ ) also at $80^{\circ} \mathrm{C}$. In fact, the broadening and increased intensity of the reflections at $22.4^{\circ}$ and $25.0^{\circ} 2 \theta \mathrm{CoK} \alpha$ points towards the presence of $\mathrm{MgKPO}_{4} \cdot \mathrm{H}_{2} \mathrm{O}$ at $50^{\circ} \mathrm{C}$

Thermodynamic modelling reproduces the trends observed experimentally: cattiite and K-struvite were calculated to be present at 5 and $20^{\circ} \mathrm{C}$, formation of MO4 at slightly above $20^{\circ} \mathrm{C}$ and destabilisation of K-struvite to $\mathrm{MgKPO}_{4} \cdot \mathrm{H}_{2} \mathrm{O}$ at around $25^{\circ} \mathrm{C}$ as shown in Figure 10B. The formation of the unidentified magnesium phosphate phase could not be reproduced due to the lack of compositional and thermodynamic data. 

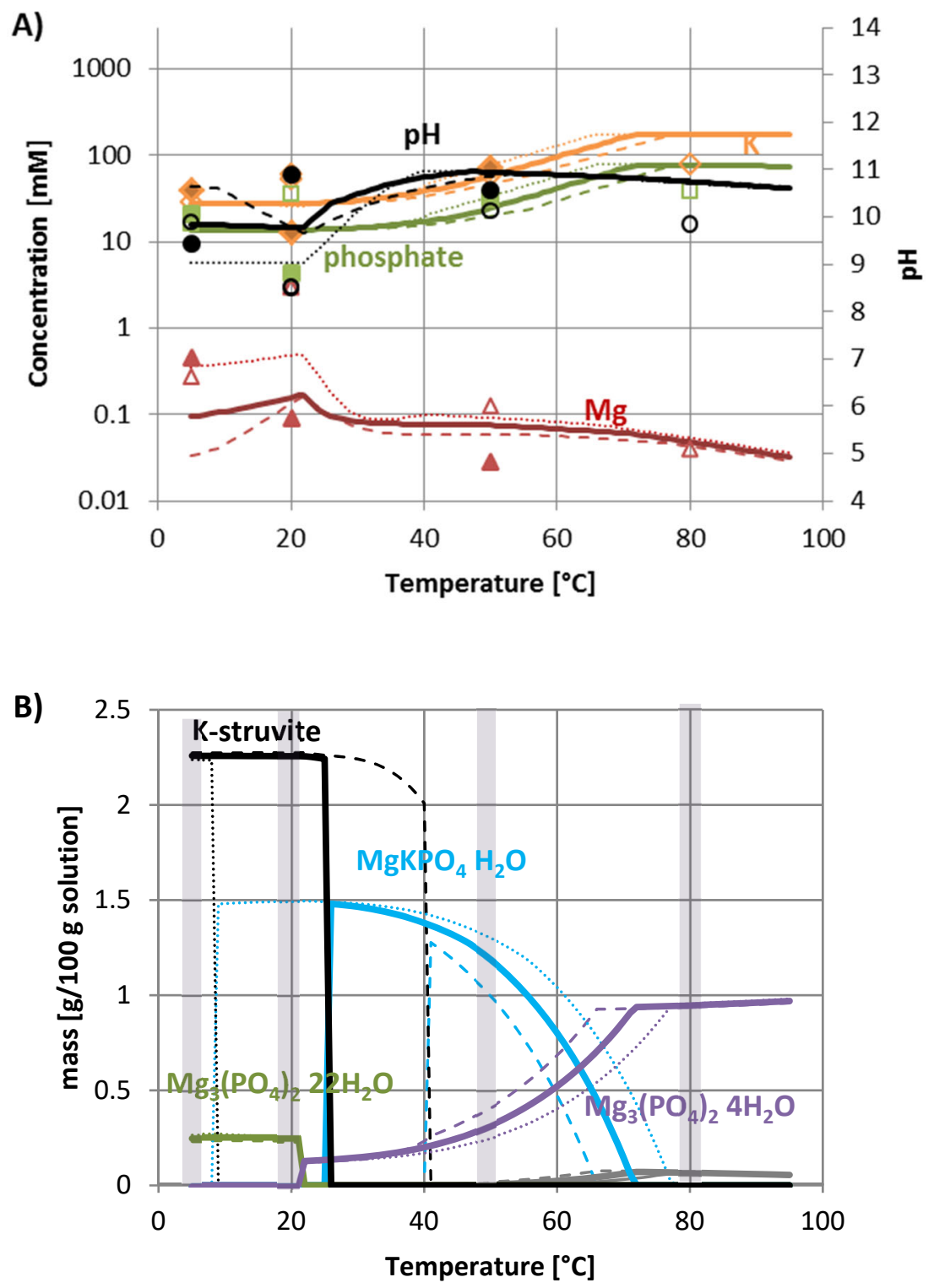


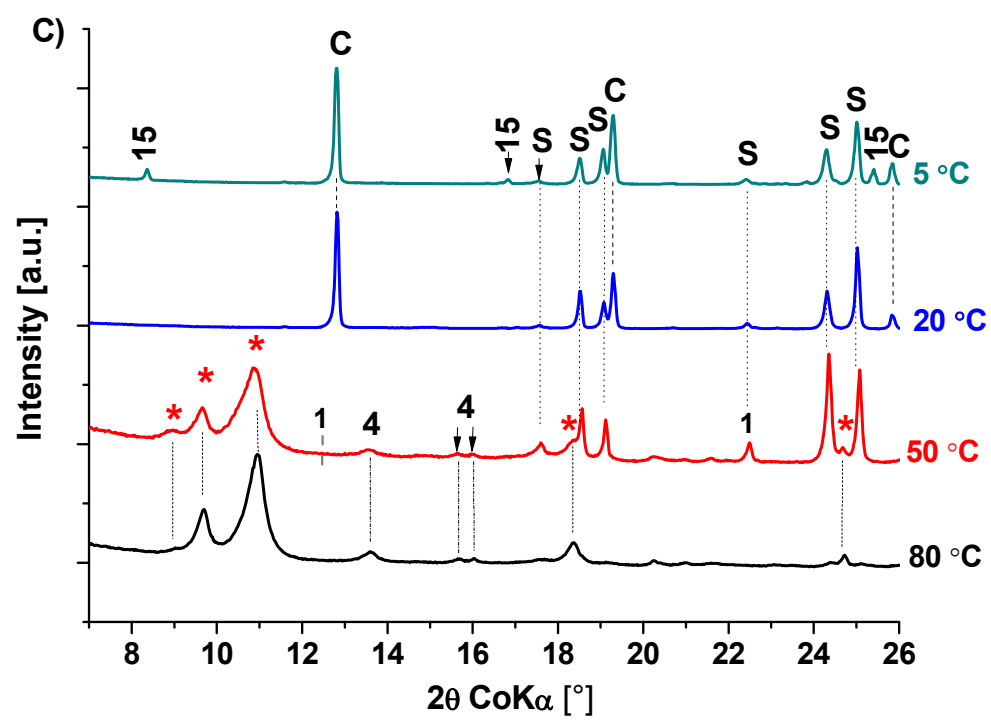

Figure 10: A) Aqueous concentrations as a function of temperature at $\mathrm{Mg} / \mathrm{PO}_{4}=1$ (sample 1_57) at 5, 20,50 and $80^{\circ} \mathrm{C}$ : solid lines: calculated concentrations; dotted and dashed lines: variation of solubility products by $\pm 0.2 \log$ units; symbols: measured values; full symbols: after $360 \mathrm{~d}\left(5,50^{\circ} \mathrm{C}\right)$ and 750 days $\left(20^{\circ} \mathrm{C}\right)$; empty symbols: after $30 \mathrm{~d}\left(5,50,80^{\circ} \mathrm{C}\right)$ or 60 days $\left(20^{\circ} \mathrm{C}\right)$. The formation of bobierrite has been supressed in the calculations as its formation at $20^{\circ} \mathrm{C}$ was kinetically hindered. B) Calculated amount of solid phases; the shadowed areas indicate the composition of the samples shown. C) XRD of sample 1_57 after $30\left(80^{\circ} \mathrm{C}\right), 360\left(5,50^{\circ} \mathrm{C}\right)$ and 750 days $\left(20^{\circ} \mathrm{C}\right) . \mathrm{C}: \mathrm{Mg}_{3}\left(\mathrm{PO}_{4}\right)_{2} \cdot 22 \mathrm{H}_{2} \mathrm{O}$; S:

$\mathrm{MgKPO}_{4} \cdot 6 \overline{\mathrm{H}}_{2} \mathrm{O} ; 1: \mathrm{MgKPO}_{4} \cdot \mathrm{H}_{2} \mathrm{O} ; 4: \mathrm{Mg}_{3}\left(\mathrm{PO}_{4}\right)_{2} \cdot 4 \mathrm{H}_{2} \mathrm{O} ; 15: \mathrm{Mg}_{2} \mathrm{KH}\left(\mathrm{PO}_{4}\right)_{2} \cdot 15 \mathrm{H}_{2} \mathrm{O}$; *: unidentified phase(s) (UP1).

Thermodynamic modelling indicates that the destabilisation of cattiite to MO4 or bobbierite occurs at slightly above $20^{\circ} \mathrm{C}$ and of $\mathrm{K}$-struvite to $\mathrm{MgKPO}_{4} \cdot \mathrm{H}_{2} \mathrm{O}$ at around $25^{\circ} \mathrm{C}$ both at high and low water to solid ratio. The calculated destabilisation of K-struvite at higher temperatures agrees with experimental data in a hydrated MKP cements where the dehydration of K-struvite at higher temperature either to $\mathrm{MgKPO}_{4} \cdot \mathrm{H}_{2} \mathrm{O}$ (Gao et al., 2016) or to a X-ray amorphous solid was reported (Gardner et al., 2015b). The formation of $\mathrm{MgKPO}_{4} \cdot \mathrm{H}_{2} \mathrm{O}$ instead of $\mathrm{K}$-struvite results in a lower volume of the hydrates, which is consistent with the observed decrease in compressive and flexural strength observed at higher temperature (Gao et al., 2016; Gardner et al., 2015b). 


\section{Conclusions}

The paper summarises a thermodynamic database built for magnesium potassium phosphate hydrates based on experimentally determined solubilities of $\mathrm{MgHPO}_{4} \cdot 3 \mathrm{H}_{2} \mathrm{O}$ (newberyite), $\mathrm{MgHPO}_{4} \cdot 7 \mathrm{H}_{2} \mathrm{O} \quad$ (phosphorrösslerite), $\quad \mathrm{MgKPO}_{4} \cdot 6 \mathrm{H}_{2} \mathrm{O} \quad$ (K-struvite), $\quad \mathrm{MgKPO}_{4} \cdot \mathrm{H}_{2} \mathrm{O}$, $\mathrm{Mg}_{2} \mathrm{KH}\left(\mathrm{PO}_{4}\right)_{2} \cdot 15 \mathrm{H}_{2} \mathrm{O}, \mathrm{Mg}_{3}\left(\mathrm{PO}_{4}\right)_{2} \cdot 4 \mathrm{H}_{2} \mathrm{O}, \mathrm{Mg}_{3}\left(\mathrm{PO}_{4}\right)_{2} \cdot 8 \mathrm{H}_{2} \mathrm{O}$ (bobierrite), and $\mathrm{Mg}_{3}\left(\mathrm{PO}_{4}\right)_{2} \cdot 22 \mathrm{H}_{2} \mathrm{O}$ (cattiite). Phosphorrösslerite is formed as an intermediate phase only and destabilises to newberyite with time. $\mathrm{Mg}_{2} \mathrm{KH}\left(\mathrm{PO}_{4}\right)_{2} \cdot 15 \mathrm{H}_{2} \mathrm{O}$ and $\mathrm{Mg}_{3}\left(\mathrm{PO}_{4}\right)_{2} \cdot 22 \mathrm{H}_{2} \mathrm{O}$ (cattiite) are stable at $20^{\circ} \mathrm{C}$ and below, while higher temperatures lead to the stabilisation of $\mathrm{Mg}_{3}\left(\mathrm{PO}_{4}\right)_{2} \cdot 4 \mathrm{H}_{2} \mathrm{O}$ and bobierrite. The precipitation of bobierrite was found to be kinetically hindered at room temperature and in the absence of calcium or potassium. In addition in some sample, the formation of an unidentified, poorly crystalline solid was observed.

Application of thermodynamic modelling to magnesium potassium phosphates and comparison with the experimental results illustrated the effect of several factors on the hydrates observed in the MKP systems

- $\mathrm{pH}$ plays a major role in the stabilisation of different solids: at low $\mathrm{pH}$ values $(\mathrm{pH}<7)$ only newberyite is expected, at intermediate $\mathrm{pH}$ values $\mathrm{Mg}_{2} \mathrm{KH}\left(\mathrm{PO}_{4}\right)_{2} \cdot 15 \mathrm{H}_{2} \mathrm{O}, \mathrm{Mg}_{3}\left(\mathrm{PO}_{4}\right)_{2} \cdot 4 \mathrm{H}_{2} \mathrm{O}$ or $\mathrm{Mg}_{3}\left(\mathrm{PO}_{4}\right)_{2} \cdot 22 \mathrm{H}_{2} \mathrm{O}$, while at $\mathrm{pH}>8$ and high $\mathrm{K}$ concentrations, $\mathrm{K}$-struvite becomes stable. This sequence also corresponds to the sequence of phases formed during the reaction of magnesium potassium phosphate cements, during the hydration of such cements a distinct $\mathrm{pH}$ increase occurs.

- An increase of the $\mathrm{Mg} / \mathrm{PO}_{4}$ has a comparable effect on the hydrates and the composition of the solution; $\mathrm{pH}$ increases, $\mathrm{Mg}$ and phosphate concentrations decrease and $\mathrm{K}$-struvite instead of newberyite is formed.

- The same sequence from low to high $\mathrm{Mg} / \mathrm{PO}_{4}$, from low to high $\mathrm{pH}$ and from newberyite to $\mathrm{K}$ struvite is also observed during the hydration of MKP cements. The dissolution of $\mathrm{KH}_{2} \mathrm{PO}_{4}$ in MKP cements occurs very fast, while the reaction of $\mathrm{MgO}$ is slower and occurs only partially, such that an hydrating MKP cement has initially a very low $\mathrm{Mg} / \mathrm{PO}_{4}$, which increases with 
time. This slow reaction of $\mathrm{MgO}$ leads initially to the formation of $\mathrm{MgHPO}_{4} \cdot 3 \mathrm{H}_{2} \mathrm{O}$ (newberyite) and $\mathrm{Mg}_{2} \mathrm{KH}\left(\mathrm{PO}_{4}\right)_{2} \cdot 15 \mathrm{H}_{2} \mathrm{O}$, which react to $\mathrm{K}$-struvite only with time.

- A decrease of the water to solid ratio increases potassium, magnesium and phosphate concentrations, which stabilises K-struvite and destabilises cattiite. In MKP cements with much higher nominal $\mathrm{Mg} / \mathrm{PO}_{4}$ ratios, the same trends have been observed. A low water to solid ratio leads to higher potassium, magnesium and phosphate concentrations and promotes the formation of K-struvite.

- An increase in temperature leads to a destabilisation of cattiite to MO4 or bobbierite occurs at slightly above $20^{\circ} \mathrm{C}$ and to a dehydration of K-struvite to $\mathrm{MgKPO}_{4} \cdot \mathrm{H}_{2} \mathrm{O}$ at above $25^{\circ} \mathrm{C}$.

The database for (potassium) magnesium phosphate hydrates derived in this paper can reliably calculate the type, composition, amount and volume of hydrates formed as a function of initial composition and temperature. The database, compiled in the Table S.1 (Supplementary Material) and in Table 5, includes carefully selected thermodynamic data based on a critical review of the available literature data supplemented with new experimental data. The magnesium phosphate database is fully compatible with the GEMS version of the PSI/Nagra 12/07 TDB (Thoenen et al., 2014; Thoenen and Kulik, 2003) and Cemdata18 database (Lothenbach et al., 2019) developed for Portland cements and blended cements. This database for magnesium potassium phosphate cements is freely downloadable at http://www.empa.ch/cemdata) in formats supporting the computer programs GEM-Selektor (Kulik et al., 2013; Wagner et al., 2012).

\section{Acknowledgements}

Saint-Gobain Recherche, France, is gratefully acknowledged for the financial support. Our thanks are extended to Sergey Lobanov for kindly providing the measured raw data from (Lobanov et al., 2013) and to Luigi Brunetti, Bin Ma, Yiru Yan, Boris Ingold (Empa) for the IC, FTIR, Raman measurements and SEM sample preparation. 


\section{References}

Aage, H., Andersen, B., Blom, A., Jensen, I., 1997. The solubility of struvite. Journal of Radioanalytical and Nuclear Chemistry 223, 213-215.

Abbona, F., Boistelle, R., Haser, R., 1979. Hydrogen-bonding in $\mathrm{MgHPO}_{4} \cdot 3 \mathrm{H}_{2} \mathrm{O}$ (newberyite). Acta Crystallogr. Sect. B-Struct. Sci. 35, 2514-2518.

Anderson, G.M., Crerar, D.A., 1993. Thermodynamics in Geochemistry: the Equilibrium Model. Oxford University Press, Oxford.

Babić-Ivančić, V., Kontrec, J., Brečević, L., Kralj, D., 2006. Kinetics of struvite to newberyite transformation in the precipitation system $\mathrm{MgCl}_{2}-\mathrm{NH}_{4} \mathrm{H}_{2} \mathrm{PO}_{4}-\mathrm{NaOH}-\mathrm{H}_{2} \mathrm{O}$. Water Res 40, 3447-3455.

Bartl, H., Catti, M., Joswig, W., Ferraris, G., 1983. Investigation of the crystal-structure of newberyite, $\mathrm{MgHPO}_{4} \cdot 3 \mathrm{H}_{2} \mathrm{O}$, by single-crystal neutron-diffraction. Tschermaks Mineralogische Und Petrographische Mitteilungen 32, 187-194.

Belopolsky, A., Shpunt, S.Y., Shulgina, M.N., 1950. Physiochemical researches in the field of magnesium phosphates (the system $\mathrm{MgO}-\mathrm{P}_{2} \mathrm{O}_{5}-\mathrm{H}_{2} \mathrm{O}$ at 25 and $80^{\circ}$ ). Journal of Applied Chemistry USSR 23, 873-884.

Ben Haha, M., Le Saout, G., Winnefeld, F., Lothenbach, B., 2011. Influence of activator type on hydration kinetics, hydrate assemblage and microstructural development of alkali activated blastfurnace slags. Cem Concr Res 41, 301-310.

Bennett, A.M., Lobanov, S., Koch, F.A., Mavinic, D.S., 2017. Improving potassium recovery with new solubility product values for K-struvite. Journal of Environmental Engineering and Science 12, 93-103.

Buj, I., Torras, J., Casellas, D., Rovira, M., de Pablo, J., 2009. Effect of heavy metals and water content on the strength of magnesium phosphate cements. Journal of Hazardous Materials 170, 345 350.

Buj, I., Torras, J., Rovira, M., de Pablo, J., 2010. Leaching behaviour of magnesium phosphate cements containing high quantities of heavy metals. Journal of Hazardous Materials 175, 789-794. Catti, M., Franchiniangela, M., Ivaldi, G., 1981. A case of polytypism in hydrated oxysalts - the crystal-structure of $\mathrm{Mg}_{3}(\mathrm{PO} 4)_{2} \cdot 22 \mathrm{H}_{2} \mathrm{O}-\mathrm{II}$. Z Kristallog 155, 53-64.

Chau, C., Qiao, F., Li, Z., 2011. Microstructure of magnesium potassium phosphate cement. Construction and Building Materials 25, 2911-2917.

Chau, C.K., Qiao, F., Li, Z., 2012. Potentiometric study of the formation of magnesium potassium phosphate hexahydrate. Journal of Materials in Civil Engineering 24, 586-591.

Coumes, C.C.D., Lambertin, D., Lahalle, H., Antonucci, P., Cannes, C., Delpech, S., 2014. Selection of a mineral binder with potentialities for the stabilization/solidification of aluminum metal. J Nucl Mater 453, 31-40.

Covill, A., Hyatt, N.C., Hill, J., Collier, N.C., 2011. Development of magnesium phosphate cements for encapsulation of radioactive waste. Adv Appl Ceram 110, 151-156.

Dilnesa, B.Z., Lothenbach, B., Renaudin, G., Wichser, A., Kulik, D., 2014. Synthesis and characterization of hydrogarnet $\mathrm{Ca}_{3}\left(\mathrm{Al}_{\mathrm{x}} \mathrm{Fe}_{1-\mathrm{x}}\right)_{2}\left(\mathrm{SiO}_{4}\right)_{\mathrm{y}}(\mathrm{OH})_{4(3-\mathrm{y})}$. Cem Concr Res 59, 96-111.

Ding, Z., Li, Z.J., 2005. High-early-strength magnesium phosphate cement with fly ash. Aci Mater J $102,375-381$.

Frank, D., 2013. Experimentelle Untersuchung und Modellierung der Fällung von KaliumMagnesium-Phosphat. PhD thesis Universität Stuttgart, Germany.

Frost, R.L., Palmer, S.J., Pogson, R.E., 2011a. Raman spectroscopy of newberyite $\mathrm{Mg}(\mathrm{PO} 3 \mathrm{OH}) \cdot 3 \mathrm{H} 2 \mathrm{O}$ : A cave mineral. Spectrochimica Acta Part A: Molecular and Biomolecular Spectroscopy 79, 1149-1153.

Frost, R.L., Palmer, S.J., Pogson, R.E., 2011b. Thermal stability of newberyite $\mathrm{Mg}\left(\mathrm{PO}_{3} \mathrm{OH}\right) \cdot 3 \mathrm{H}_{2} \mathrm{O}$ : A cave mineral from Skipton Lava Tubes, Victoria, Australia. Journal of Thermal Analysis and Calorimetry 107, 1143-1146.

Frost, R.L., Weier, M.L., Martens, W.N., Henry, D.A., Mills, S.J., 2005. Raman spectroscopy of newberyite, hannayite and struvite. Spectrochimica Acta Part A: Molecular and Biomolecular Spectroscopy 62, 181-188. 
Gao, X., Zhang, A., Li, S., Sun, B., Zhang, L., 2016. The resistance to high temperature of magnesia phosphate cement paste containing wollastonite. Materials and Structures 49, 3423-3434.

Gardner, L.J., Bernal, S.A., Walling, S.A., Corkhill, C.L., Provis, J.L., Hyatt, N.C., 2015 a. Characterisation of magnesium potassium phosphate cements blended with fly ash and ground granulated blast furnace slag. Cement and Concrete Research 74, 78-87.

Gardner, L.J., Lejeune, V., Corkhill, C.L., Bernal, S.A., Provis, J.L., Stennett, M.C., Hyatt, N.C., $2015 \mathrm{~b}$. Evolution of phase assemblage of blended magnesium potassium phosphate cement binders at 200 and $1000^{\circ} \mathrm{C}$. Adv Appl Ceram 114, 386-392.

Graeser, S., Postl, W., Bojar, H.P., Berlepsch, P., Armbruster, T., Raber, T., Ettinger, K., Walter, F., 2008. Struvite-(K), $\mathrm{KMgPO}_{4} \cdot 6 \mathrm{H}_{2} \mathrm{O}$, the potassium equivalent of struvite - a new mineral. Eur J

Mineral 20, 629-633.

Helgeson, H.C., Delany, J.M., Nesbitt, H.W., Bird, D.K., 1978. Summary and critique of the thermodynamic properties of rock-forming minerals. Am J Sci 278-A, 1-229.

Holt, L.E., Pierce, J.A., Kajdi, C.N., 1954. The solubility of the phosphates of strontium, barium, and magnesium and their relation to the problem of calcification. Journal of Colloid Science 9, 409-426.

Johnson, J.W., Oelkers, E.H., Helgeson, H.C., 1992. SUPCRT92: A software package for calculating the standard molal thermodynamic properties of minerals, gases, aqueous species, and reactions from 1 to 5000 bar and 0 to $1000^{\circ} \mathrm{C}$. Comput Geosci 18, 899-947.

Koleva, V., Stefov, V., Najdoski, M., 2017. Characterization and thermal decomposition of $\mathrm{Mg}_{2} \mathrm{KH}\left(\mathrm{AsO}_{4}\right) 2 \cdot 15 \mathrm{H}_{2} \mathrm{O}$. Journal of Thermal Analysis and Calorimetry 127, 1911-1919.

Koleva, V., Stefov, V., Najdoski, M., Cahil, A., 2015. Thermal, spectral and microscopic studies of water-rich hydrate of the type $\mathrm{Mg}_{2} \mathrm{KH}\left(\mathrm{PO}_{4}\right)_{2} \cdot 15 \mathrm{H}_{2} \mathrm{O}$. Thermal transformations. Thermochimica Acta 619, 20-25.

Kongshaug, K.O., Fjellvag, H., Lillerud, K.P., 2001. The synthesis and crystal structure of a hydrated magnesium phosphate $\mathrm{Mg}_{3}(\mathrm{PO} 4)_{2} \cdot 4 \mathrm{H}_{2} \mathrm{O}$. Solid State Sci. 3, 353-359.

Kulik, D., Wagner, T., Dmytrieva, S., Kosakowski, G., Hingerl, F., Chudnenko, K., Berner, U., 2013. GEM-Selektor geochemical modeling package: revised algorithm and GEMS3K numerical kernel for coupled simulation codes. Computational Geosciences 17, 1-24.

Kulik, D.A., 2002. Minimising uncertainty induced by temperature extrapolations of thermodynamic data: A pragmatic view on the integration of thermodynamic databases into geochemical computer

codes, Workshop on the use of thermodynamic databases in performance assessment. . OECD, Paris, France, Barcelona, Spain.

La Iglesia, A., 2009. Estimating the thermodynamic properties of phosphate minerals at high and low temperature from the sum of constituent units. Estudios Geologicos (Madrid) 65, 109-119.

Lahalle, H., Cau Dit Coumes, C., Mercier, C., Lambertin, D., Cannes, C., Delpech, S., Gauffinet, S., 2018. Influence of the $\mathrm{w} / \mathrm{c}$ ratio on the hydration process of a magnesium phosphate cement and on its retardation by boric acid. Cem Concr Res 109, 159-174.

Lahalle, H., Cau Dit Coumes, C., Mesbah, A., Lambertin, D., Cannes, C., Delpech, S., Gauffinet, S., 2016. Investigation of magnesium phosphate cement hydration in diluted suspension and its retardation by boric acid. Cem Concr Res 87, 77-86.

Le Rouzic, M., 2014. Étude des propriétés physico-chimiques et mécaniques des matériaux cimentaires à base d'oxyde de magnésium. PhD thesis Université Paris-Est, France.

Le Rouzic, M., Chaussadent, T., Platret, G., Stefan, L., 2017a. Mechanisms of k-struvite formation in magnesium phosphate cements. Cem Concr Res 91, 117-122.

Le Rouzic, M., Chaussadent, T., Stefan, L., Saillio, M., 2017b. On the influence of Mg/P ratio on the properties and durability of magnesium potassium phosphate cement pastes. Cement and Concrete Research 96, 27-41.

Lee, K.H., Yoon, H.S., Yang, K.H., 2017. Tests on magnesium potassium phosphate composite mortars with different water-to-binder ratios and molar ratios of magnesium-to phosphate.

Construction and Building Materials 146, 303-311.

Li, Y., Bai, W., Shi, T., 2017. A study of the bonding performance of magnesium phosphate cement on mortar and concrete. Construction and Building Materials 142, 459-468.

Lobanov, S., 2018. personal communication 14.8.2018.

Lobanov, S., Koch, F., Mavinic, D., 2013. The implication of aqueous equilibrium modelling to evaluate the potential for nutrient recovery from wastewater streams. WEF/IWA Nutrient Removal and Recovery: Trends in Resource Recovery and Use, Vancouver, BC, Canada.(USB proceedings). 
Lodders, K., 1999. Revised thermochemical properties of phosphinidene ( $\mathrm{PH})$, phosphine $\left(\mathrm{PH}_{3}\right)$, phosphorus nitride $(\mathrm{PN})$, and magnesium phosphate $\left(\mathrm{Mg}_{3} \mathrm{P}_{2} \mathrm{O}_{8}\right)$. Journal of Physical and Chemical Reference Data 28, 1705-1712.

Lothenbach, B., Bernard, E., Mäder, U., 2017. Zeolite formation in the presence of cement hydrates and albite. Phys Chem Earth 99, 77-94.

Lothenbach, B., Durdzinski, P., de Weerdt, K., 2016. Thermogravimetric analysis, in: Scrivener, K.L., Snellings, R., Lothenbach, B. (Eds.), A Practical Guide to Microstructural Analysis of Cementitious Materials. CRC Press, Oxford, UK, pp. 179-213.

Lothenbach, B., Kulik, D., Matschei, T., Balonis, M., Baquerizo, L.G., Dilnesa, B.Z., Miron, G.D., Myers, D., 2019. Cemdata18: A thermodynamic database for hydrated Portland cements and alkaliactivated materials. Cem Concr Res 115, 472-506.

Lothenbach, B., Le Saout, G., Gallucci, E., Scrivener, K., 2008. Influence of limestone on the hydration of Portland cements. Cement and Concrete Research 38, 848-860.

Lothenbach, B., Pelletier-Chaignat, L., Winnefeld, F., 2012. Stability in the system $\mathrm{CaO}-\mathrm{Al}_{2} \mathrm{O}_{3}-\mathrm{H}_{2} \mathrm{O}$

Cem Concr Res 42, 1621-1634.

Lothenbach, B., Scrivener, K., Hooton, R.D., 2011. Supplementary cementitious materials. Cem Concr Res 41, 1244-1256.

Lothenbach, B., Winnefeld, F., 2006. Thermodynamic modelling of the hydration of Portland cement. Cement and Concrete Research 36, 209-226.

Luff, B.B., Reed, R.B., 1980. Thermodynamic properties of magnesium potassium orthophosphate hexahydrate. Journal of Chemical and Engineering Data 25, 310-312.

Ma, H.Y., Xu, B.W., 2017. Potential to design magnesium potassium phosphate cement paste based on an optimal magnesia-to-phosphate ratio. Mater Design 118, 81-88.

Ma, H.Y., Xu, B.W., Li, Z.J., 2014a. Magnesium potassium phosphate cement paste: Degree of reaction, porosity and pore structure. Cement and Concrete Research 65, 96-104.

Ma, H.Y., Xu, B.W., Liu, J., Pei, H.F., Li, Z.J., 2014b. Effects of water content, magnesia-tophosphate molar ratio and age on pore structure, strength and permeability of magnesium potassium phosphate cement paste. Mater Design 64, 497-502.

Mácová, P., Viani, A., 2017. Investigation of setting reaction in magnesium potassium phosphate ceramics with time resolved infrared spectroscopy. Materials Letters 205, 62-66.

Mathew, M., Schroeder, L., 1979. Crystal structure of a struvite analogue, MgKPO4. 6H2O. Acta Crystallographica Section B: Structural Crystallography and Crystal Chemistry 35, 11-13.

Matschei, T., Lothenbach, B., Glasser, F.P., 2007. Thermodynamic properties of Portland cement hydrates in the system $\mathrm{CaO}-\mathrm{Al}_{2} \mathrm{O}_{3}-\mathrm{SiO}_{2}-\mathrm{CaSO}_{4}-\mathrm{CaCO}_{3}-\mathrm{H}_{2} \mathrm{O}$. Cem Concr Res 37, 1379-1410.

Merkel, B.J., Planer-Friederich, B., 2008. Groundwater Geochemistry. A Practical Guide to Modeling of Natural and Contaminated Aquatic Systems. Springer Berlin.

Myers, R.J., Lothenbach, B., Bernal, S., Provis, J.L., 2015. Thermodynamic modelling of alkaliactivated slag-based cements. Appl Geochem 61, 233-247.

Nied, D., Enemark-Rasmussen, K., L'Hôpital, E., Skibsted, J., Lothenbach, B., 2016. Properties of magnesium silicate hydrates (M-S-H). Cem Concr Res 79, 323-332.

Oeting, F.L., McDonald, R.A., 1963. The thermodynamic properties of magnesium orthophosphate and magnesium pyrophosphate. J Phys Chem 67, 2737-2743.

Pecovska-Gjorgjevich, M., Stefov, V., Najdoski, M., Koleva, V., Mentus, S., Petruševski, G., 2018. $\mathrm{Mg}_{2} \mathrm{KH}\left(\mathrm{XO}_{4}\right)_{2} \cdot 15 \mathrm{H}_{2} \mathrm{O}(\mathrm{X}=\mathrm{P}, \mathrm{As})$ containing acidic dimer units: Electrochemical impedance spectroscopy, IR spectroscopy and DSC studies. Journal of Alloys and Compounds 746, 699-709. Qiao, F., Chau, C.K., Li, Z., 2010. Property evaluation of magnesium phosphate cement mortar as patch repair material. Construction and Building Materials 24, 695-700.

Racz, G., Soper, R., 1968. Solubility of dimagnesium phosphate trihydrate and trimagnesium phosphate. Canadian Journal of Soil Science 48, 265-269.

Schroeder, L.W., Mathew, M., Brown, W.E., 1978. $\mathrm{XO}_{4}{ }^{\text {n- }}$ ion hydration - crystal-structure of $\mathrm{Mg}_{3}\left(\mathrm{PO}_{4}\right)_{2} \cdot 22 \mathrm{H}_{2} \mathrm{O}$. J. Phys. Chem. 82, 2335-2340.

Smith, R.M., Martell, A.E., 1976. Critical Stability Constants [Elektronische Ressource] : Inorganic Complexes / by Robert M. Smith, Arthur E. Martell.

Snellings, R., Chwast, J., Cizer, Ö., De Belie, N., Dhandapani, Y., Durdzinski, P., Elsen, J., Haufe, J., Hooton, D., Patapy, C., Santhanam, M., Scrivener, K., Snoeck, D., Steger, L., Tongbo, S., Vollpracht, 
A., Winnefeld, F., Lothenbach, B., 2018. RILEM TC-238 SCM recommendation on hydration stoppage by solvent exchange for the study of hydrate assemblages. Materials and Structures 51, 172. Stefov, V., Koleva, V., Najdoski, M., Abdija, Z., Cahil, A., Šoptrajanov, B., 2017. Vibrational spectra of $\mathrm{Mg}_{2} \mathrm{KH}\left(\mathrm{XO}_{4}\right)_{2} \cdot 15 \mathrm{H}_{2} \mathrm{O}(\mathrm{X}=\mathrm{P}, \mathrm{As})$ containing dimer units $\left[\mathrm{H}\left(\mathrm{XO}_{4}\right)_{2}\right]$. Spectrochimica Acta Part A: Molecular and Biomolecular Spectroscopy 183, 387-394.

Stefov, V., Šoptrajanov, B., Spirovski, F., Kuzmanovski, I., Lutz, H.D., Engelen, B., 2004. Infrared and Raman spectra of magnesium ammonium phosphate hexahydrate (struvite) and its isomorphous analogues. I. Spectra of protiated and partially deuterated magnesium potassium phosphate hexahydrate. Journal of Molecular Structure 689, 1-10.

Street, R.L.T., Whitaker, A., 1973. Isostructurality of rosslerite and phosphorrosslerite. Z Kristallog 137, 246-255.

Sutor, D.J., 1967. Crystal and molecular structure of newberyite $\mathrm{MgHPO}_{4} \cdot 3 \mathrm{H}_{2} \mathrm{O}$. Acta Crystallogr 23, 418-\&.

Tabor, H., Hastings, A.B., 1943. The ionization constant of secondary magnesium phosphate. Journal of Biological Chemistry 148, 627-632.

Takagi, S., Mathew, M., Brown, W.E., 1982. Water-rich hydrates - the structures of dimagnesium potassium hydrogenbis(arsenate) 15-hydrate and dimagnesium potassium hydrogenbis(phosphate) 15hydrate. Acta Crystallogr. Sect. B-Struct. Sci. 38, 44-50.

Takagi, S., Mathew, M., Brown, W.E., 1986. Crystal-structures of bobierrite and synthetic $\mathrm{Mg}_{3}\left(\mathrm{PO}_{4}\right)_{2} \cdot 8 \mathrm{H}_{2} \mathrm{O}$. Am Min 71, 1229-1233.

Taylor, A., Frazier, A., Gurney, E., 1963a. Solubility products of magnesium ammonium and magnesium potassium phosphates. Transactions of the Faraday Society 59, 1580-1584.

Taylor, A.W., Frazier, A.W., Gurney, E.L., Smith, J.P., 1963b. Solubility products of di-and trimagnesium phosphates and the dissociation of magnesium phosphate solutions. Transactions of the Faraday Society 59, 1585-1589.

Thoenen, T., Hummel, W., Berner, U., Curti, E., 2014. The PSI/Nagra Chemical Thermodynamic Data Base 12/07. PSI report 14-04, Villigen PSI, Switzerland.

Thoenen, T., Kulik, D.A., 2003. Nagra/PSI Chemical Thermodynamic Data Base 01/01 for the GEMSelektor (V.2- PSI) Geochemical Modeling Code: Release 28-02-03. Internal Report TM-44-03-04. available from http://gems.web.psi.ch/TDB/doc/pdf/TM-44-03-04-web.pdf (checked 2018-04-19). Turner, D., Whitfield, M., Dickson, A., 1981. The equilibrium speciation of dissolved components in freshwater and sea water at $25^{\circ} \mathrm{C}$ and $1 \mathrm{~atm}$ pressure. Geochimica et Cosmochimica Acta 45, 855-881. Verbeeck, R., De Bruyne, P., Driessens, F., Verbeek, F., 1984. Solubility of magnesium hydrogen phosphate trihydrate and ion-pair formation in the system magnesium hydroxide-phosphoric acidwater at $25^{\circ} \mathrm{C}$. Inorganic Chemistry 23, 1922-1926.

Vieillard, P., Tardy, Y., 1984. Thermochemical properties of phosphates. Phosphate minerals 4. Wagh, A.S., 2004. Chemically Bonded Phosphate Ceramics. Elsevier Science.

Wagner, T., Kulik, D.A., Hingerl, F.F., Dmytrieva, S.V., 2012. GEM-Selektor geochemical modeling package: TSolMod library and data interface for multicomponent phase models. Canadian Mineralogist 50, 1173-1195.

Walling, S.A., Provis, J.L., 2016. Magnesia-based cements: a journey of 150 years, and cements for the future? Chem Rev 116, 4170-4204.

Wang, A.J., Zhang, J., Li, J.M., Ma, A.B., Liu, L.T., 2013. Effect of liquid-to-solid ratios on the properties of magnesium phosphate chemically bonded ceramics. Mat Sci Eng C-Mater 33, 2508 2512.

Webber, M., Racz, G., 1970. Soluble complexes in the systems dicalcium phosphate dihydrate or dimagnesium phosphate trihydrate equilibrated with aqueous salt solutions. Canadian Journal of Soil Science 50, 243-253.

Winnefeld, F., Lothenbach, B., 2010. Hydration of calcium sulfoaluminate cements - Experimental findings and thermodynamic modelling. Cement and Concrete Research 40, 1239-1247.

Winnefeld, F., Schöler, A., Lothenbach, B., 2016. Sample preparation, in: Scrivener, K.L., Snellings, R., Lothenbach, B. (Eds.), A Practical Guide to Microstructural Analysis of Cementitious Materials. CRC Press, Oxford, UK, pp. 1-35.

Xu, B., Lothenbach, B., Leemann, A., Winnefeld, F., 2018a. Reaction mechanism of magnesium potassium phosphate cement with high magnesia-to-phosphate ratio. Cem Concr Res 108, 140-151. 
Xu, B., Lothenbach, B., Ma, H., 2018b. Properties of fly ash blended magnesium potassium phosphate mortars: effect of the ratio between fly ash and magnesia. Cement \& Concrete Composites 90, 169177.

Xu, B., Ma, H., Shao, H., Li, Z., Lothenbach, B., 2017. Influence of fly ash on compressive strength and micro-characteristics of magnesium potassium phosphate cement mortars. Cement and Concrete Research 99, 86-94.

Xu, B., Winnefeld, F., Kaufmann, J., Lothenbach, B., 2019. Influence of magnesium-to-phosphate ratio and water-to-cement ratio on hydration and properties of magnesium potassium phosphate cements. Cement and Concrete Research, submitted.

Xu, B.W., Ma, H.Y., Li, Z.J., 2015. Influence of magnesia-to-phosphate molar ratio on microstructures, mechanical properties and thermal conductivity of magnesium potassium phosphate cement paste with large water-to-solid ratio. Cement and Concrete Research 68, 1-9.

Yang, Y., Liu, J., Wang, B., Liu, R., Zhang, T., 2019. A thermodynamic modeling approach for solubility product from struvite-K. Computational Materials Science 157, 51-59.

Yue, L., Jia, S., Bing, C., 2014. Experimental study of magnesia and M/P ratio influencing properties of magnesium phosphate cement. Construction and Building Materials 65, 177-183.

Zhang, T., Chen, H., Li, X., Zhu, Z., 2017. Hydration behavior of magnesium potassium phosphate cement and stability analysis of its hydration products through thermodynamic modeling. Cem Concr Res 98, 101-110. 